Prepared in cooperation with the

New York State Department of Environmental Conservation

\title{
Groundwater Quality in the Delaware and St. Lawrence River Basins, New York, 2010
}

Open-File Report 2011-1320 
Cover. Snow geese and water towers, Malone, New York. 


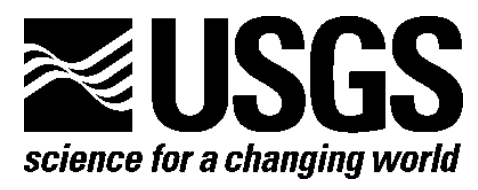

Prepared in cooperation with the New York State Department of Environmental Conservation

\section{Groundwater Quality in the Delaware and St. Lawrence River Basins, New York, 2010}

By Elizabeth A. Nystrom

Open-File Report 2011-1320 


\section{U.S. Department of the Interior \\ KEN SALAZAR, Secretary}

\section{U.S. Geological Survey \\ Marcia K. McNutt, Director}

U.S. Geological Survey, Reston, Virginia: 2012

For product and ordering information:

World Wide Web: http://www.usgs.gov/pubprod

Telephone: 1-888-ASK-USGS

For more information on the USGS-the Federal source for science about the Earth,

its natural and living resources, natural hazards, and the environment:

World Wide Web: http://www.usgs.gov

Telephone: 1-888-ASK-USGS

Suggested citation:

Nystrom, E.A., 2012, Groundwater quality in the Delaware and St. Lawrence River Basins, New York, 2010: U.S.

Geological Survey Open-File Report 2011-1320, 58 p., at http://pubs.usgs.gov/of/2011/1320/.

Any use of trade, product, or firm names is for descriptive purposes only and does not imply endorsement by the U.S. Government.

Although this report is in the public domain, permission must be secured from the individual copyright owners to reproduce any copyrighted material contained within this report. 


\section{Contents}

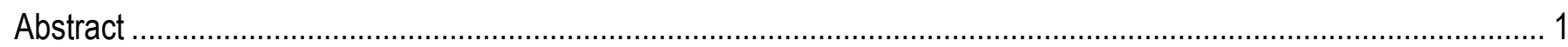

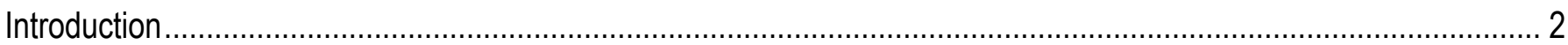

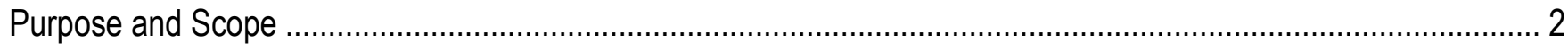

Hydrogeologic Setting of the Delaware River Basin in New York ................................................................. 3

Hydrogeologic Setting of the St. Lawrence River Basin in New York ............................................................... 5

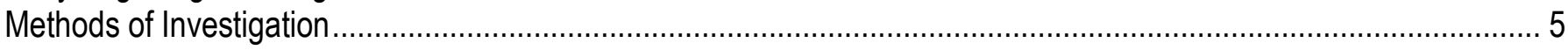

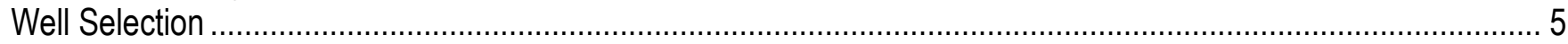

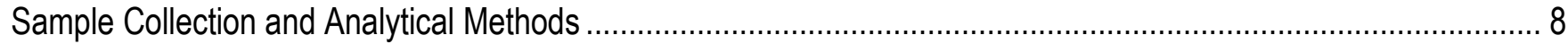

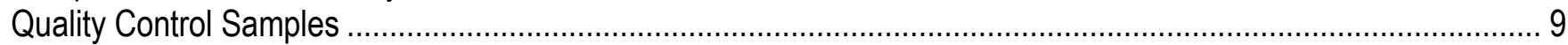

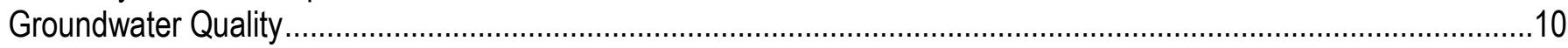

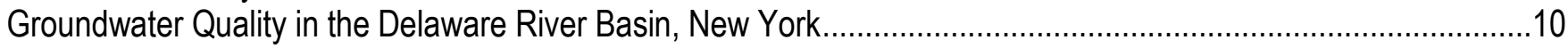

Physiochemical Properties .........................................................................................................11

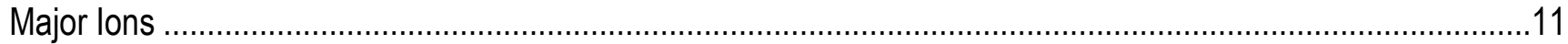

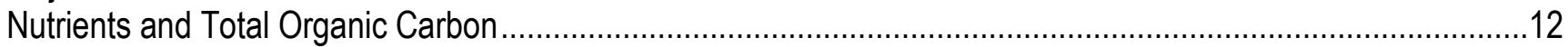

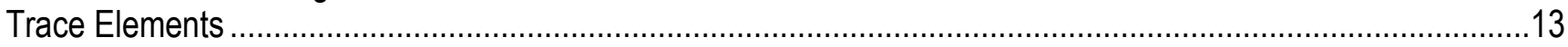

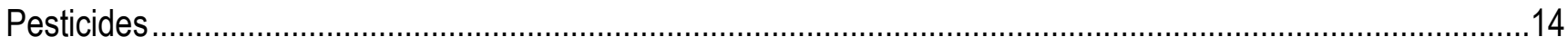

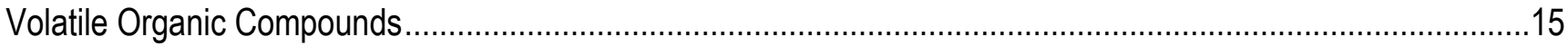

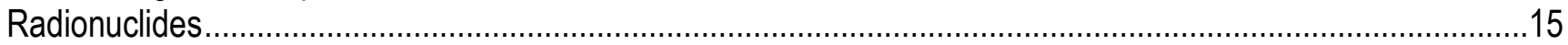

Bacteria

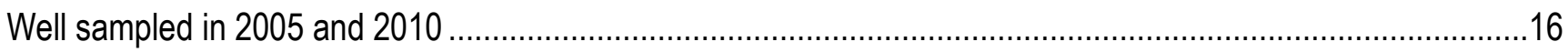

Groundwater Quality in the St. Lawrence River Basin, New York ...................................................................16

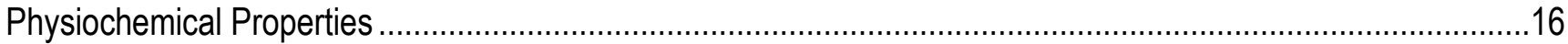

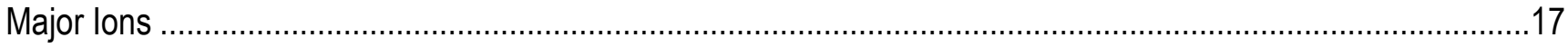

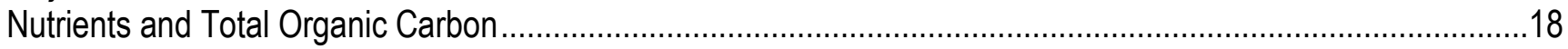

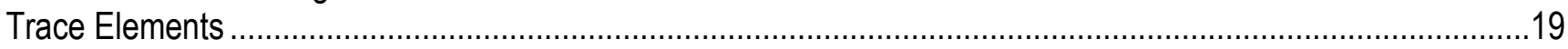

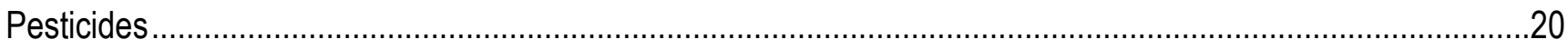

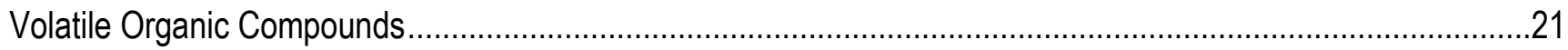

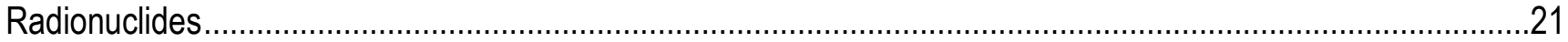

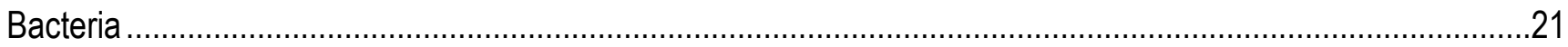

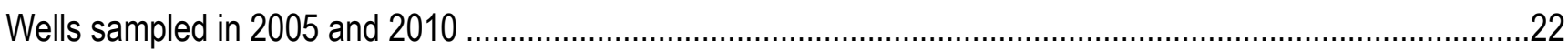

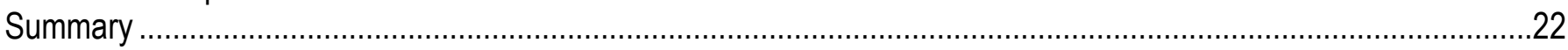

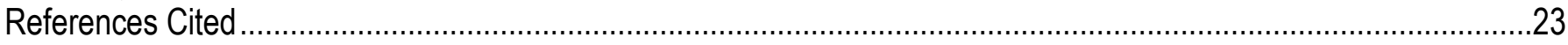

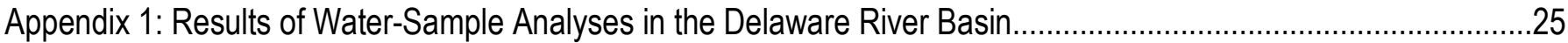

Appendix 2: Results of Water-Sample Analyses in the St. Lawrence River Basin ....................................................39

\section{Figures}

Maps showing:

Figure 1. Generalized bedrock geology of the Delaware River Basin, New York, and locations of wells sampled in 2010.

Figure 2. Generalized surficial geology of the Delaware River Basin, New York, and locations of wells sampled in 2010.

Figure 3. Generalized bedrock geology of the St. Lawrence River Basin, New York, and locations of wells sampled in 2010.

Figure 4. Generalized surficial geology of the St. Lawrence River Basin, New York, and locations of wells sampled in 2010. 


\section{Tables}

Table 1. Previous groundwater-quality studies and reports........................................................................ 2

Table 2. Information on wells from which water samples were collected in the Delaware River Basin, New York,

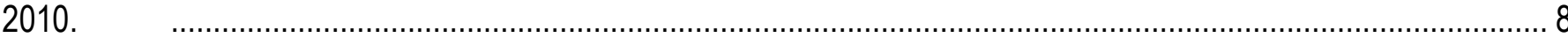

Table 3. Information on wells from which water samples were collected in the St. Lawrence River Basin, New York, 2010.

Table 4. Summary of information on wells from which water samples were collected in the Delaware River Basin,

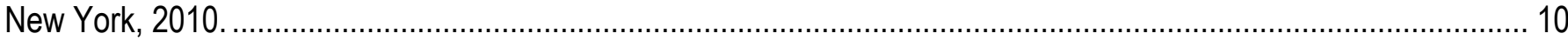

Table 5. Summary of information on wells from which water samples were collected in the St. Lawrence River Basin, New York, 2010

Table 6. Drinking-water standards and summary statistics for physiochemical properties of groundwater samples from the Delaware River Basin, New York, 2010..................................................................................... 11

Table 7. Drinking-water standards and summary statistics for concentrations of major ions in groundwater samples from the Delaware River Basin, New York, 2010 ........................................................................... 12 Table 8. Drinking-water standards and summary statistics for concentrations of nutrients in groundwater samples

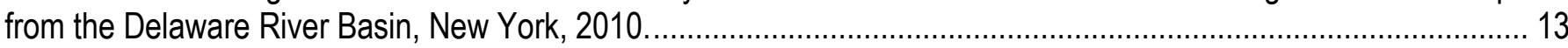
Table 9. Drinking-water standards and summary statistics for concentrations of trace elements in groundwater samples from the Delaware River Basin, New York, 2010

Table 10. Drinking-water standards and summary statistics for concentrations of radionuclides in groundwater samples from the Delaware River Basin, New York, 2010.

Table 11. Drinking-water standards and summary statistics for physiochemical properties of groundwater samples from the St. Lawrence River Basin, New York, 2010.

Table 12. Drinking-water standards and summary statistics for concentrations of major ions in groundwater samples from the St. Lawrence River Basin, New York, 2010.

Table 13. Drinking-water standards and summary statistics for concentrations of nutrients in groundwater samples

from the St. Lawrence River Basin, New York, 2010.

Table 14. Drinking-water standards and summary statistics for concentrations of trace elements in groundwater samples from the St. Lawrence River Basin, New York, 2010.

Table 15. Drinking-water standards and summary statistics for activities of radionuclides in groundwater samples from the St. Lawrence River Basin, New York, 2010.

\section{Appendix 1}

Table 1-1. Constituents that were not detected in groundwater samples collected in the Delaware River Basin, New York, 2010.

Table 1-2. Physiochemical properties of groundwater samples collected in the Delaware River Basin, New York, 2010.

Table 1-3. Concentrations of major ions in groundwater samples collected in the Delaware River Basin, New York, 2010.

Table 1-4. Concentrations of nutrients and organic carbon in groundwater samples collected in the Delaware River Basin, New York, 2010 ................................................................................................................. 30

Table 1-5. Concentrations of trace elements in groundwater samples collected in the Delaware River Basin, New York, 2010.

Table 1-6. Concentrations of pesticides detected in groundwater samples collected in the Delaware River Basin, New York, 2010.

Table 1-7. Concentrations of volatile organic compounds detected in groundwater samples collected in the Delaware River Basin, New York, 2010.

Table 1-8. Activities of radionuclides in groundwater samples from the Delaware River Basin, New York, 2010. 33 
Table 1-9. Bacteria in groundwater samples collected in the Delaware River Basin, New York, 2010.

Table 1-10. Physiochemical properties and concentrations of major ions, nutrients, and bacteria in groundwater samples collected in the Delaware River Basin, New York, 2005 and 2010.

Table 1-11. Concentrations of trace elements and radionuclides in groundwater samples in the Delaware River Basin, New York, 2005 and 2010.

Table 1-12. Concentrations of pesticides in groundwater samples collected in the Delaware River Basin, New York, 2005 and 2010.

Table 1-13. Concentrations of volatile organic compounds in groundwater samples collected in the Delaware River

Basin, New York, 2005 and 2010.

\section{Appendix 2}

Table 2-1. Constituents that were not detected in groundwater samples collected in the St. Lawrence River Basin, New York, 2010.

Table 2-2. Physiochemical properties of groundwater samples collected in the St. Lawrence River Basin, New York, 2010.

Table 2-3. Concentrations of major ions in groundwater samples collected in the St. Lawrence River Basin, New

York, 2010.

Table 2-4. Concentrations of nutrients and organic carbon in groundwater samples collected in the St. Lawrence

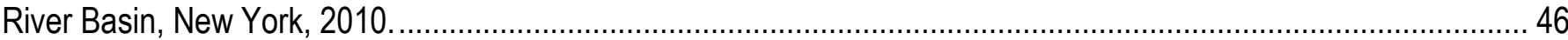

Table 2-5. Concentrations of trace elements in groundwater samples collected in the St. Lawrence River Basin, New York, 2010.

Table 2-6. Concentrations of pesticides detected in groundwater samples collected in the St. Lawrence River Basin, New York, 2010.

Table 2-7. Concentrations of volatile organic compounds detected in groundwater samples collected in the St. Lawrence River Basin, New York, 2010.

Table 2-8. Activities of radionuclides in groundwater samples from the St. Lawrence River Basin, New York, 2010.

Table 2-9. Bacteria in groundwater samples collected in the St. Lawrence River Basin, New York, 2010.

Table 2-10. Physiochemical properties and concentrations of major ions, nutrients, and bacteria in groundwater samples collected in the St. Lawrence River Basin, New York, 2005 and 2010.

Table 2-11. Concentrations of trace elements and radionuclides in groundwater samples collected in the St. Lawrence River Basin, New York, 2005 and 2010

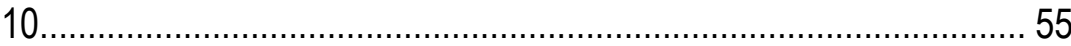

Table 2-12. Concentrations of pesticides in groundwater samples collected in St. Lawrence River Basin, New York, 2005 and 2010 ......

Table 2-13. Concentrations of volatile organic compounds in groundwater samples collected in the St. Lawrence River Basin, New York, 2005 and 2010. 
Conversion Factors, Datum, and Acronyms

\begin{tabular}{lcl}
\hline \multicolumn{1}{c}{ Multiply } & \multicolumn{1}{c}{ By } & \multicolumn{1}{c}{ To obtain } \\
\hline inch (in.) & Length & \\
foot (ft) & 2.54 & centimeter $(\mathrm{cm})$ \\
mile (mi) & 0.3048 & meter (m) \\
\hline & 1.609 & kilometer $(\mathrm{km})$ \\
\hline acre & Area & \\
square mile $\left(\mathrm{mi}^{2}\right)$ & 0.004047 & square kilometer $\left(\mathrm{km}^{2}\right)$ \\
\hline & 2.590 & square kilometer $\left(\mathrm{km}^{2}\right)$ \\
\hline gallon (gal) & Volume & \\
liter (L) & 3.785 & liter $(\mathrm{L})$ \\
\hline & 0.2642 & gallon (gal) \\
\hline gallon per minute (gal/min) & Flow rate & \\
\hline & 0.06309 & liter per second $(\mathrm{L} / \mathrm{s})$ \\
\hline inch of mercury at $60^{\circ} \mathrm{F}($ in $\mathrm{Hg})$ & Pressure & \\
\hline & 3.377 & kilopascal $(\mathrm{kPa})$ \\
\hline picocurie per liter (pCi/L) & Radioactivity \\
\hline
\end{tabular}

Temperature in degrees Celsius $\left({ }^{\circ} \mathrm{C}\right)$ may be converted to degrees Fahrenheit $\left({ }^{\circ} \mathrm{F}\right)$ as follows:

${ }^{\circ} \mathrm{F}=\left(1.8 \mathrm{x}^{\circ} \mathrm{C}\right)+32$

Vertical coordinate information is referenced to the insert North American Vertical Datum of 1988 (NAVD 88).

Elevation, as used in this report, refers to distance above the vertical datum.

Horizontal coordinate information is referenced to North American Datum of 1983 (NAD 83).

Specific conductance is given in microsiemens per centimeter at 25 degrees Celsius $\left(\mu \mathrm{S} / \mathrm{cm}\right.$ at $\left.25^{\circ} \mathrm{C}\right)$.

Concentrations of chemical constituents in water are given either in milligrams per liter ( $\mathrm{mg} / \mathrm{L})$ or micrograms per liter $(\mu \mathrm{g} / \mathrm{L})$.

Radiochemical activities are given in picocuries per liter (pCi/L). 


\section{Acronyms used in this report}

$\begin{array}{ll}\text { AMCL } & \text { Alternative maximum contaminant level } \\ \text { CFCL } & \text { USGS Chlorofluorocarbon Laboratory } \\ \text { CFU } & \text { Colony-forming units } \\ \text { CIAT } & \text { 2-Chloro-4-isopropylamino-6-amino-s-triazine } \\ \text { LRL } & \text { Laboratory reporting level } \\ \text { MCL } & \text { Maximum contaminant level } \\ \text { NAD 83 } & \text { North American Datum of 1983 } \\ \text { NAVD 88 } & \text { North American Vertical Datum of 1988 } \\ \text { NWQL } & \text { USGS National Water Quality Laboratory } \\ \text { NYSDEC } & \text { New York State Department of Environmental Conservation } \\ \text { NYSDOH } & \text { New York State Department of Health } \\ \text { SDWS } & \text { Secondary drinking-water standards } \\ \text { THM } & \text { Trihalomethane } \\ \text { USEPA } & \text { U.S. Environmental Protection Agency } \\ \text { USGS } & \text { U.S. Geological Survey } \\ \text { VOC } & \text { Volatile organic compound }\end{array}$


This page has been left blank intentionally. 


\title{
Groundwater Quality in the Delaware and St. Lawrence River Basins, New York, 2010
}

\author{
By Elizabeth A. Nystrom
}

\section{Abstract}

Water samples were collected from 10 production and domestic wells in the Delaware River Basin in New York and from 20 production and domestic wells in the St. Lawrence River Basin in New York from August through November 2010 to characterize groundwater quality in the basins. The samples were collected and processed by standard U.S. Geological Survey procedures and were analyzed for 147 physiochemical properties and constituents, including major ions, nutrients, trace elements, pesticides, volatile organic compounds (VOCs), radionuclides, and indicator bacteria.

The Delaware River Basin covers 2,360 square miles in New York, and is underlain mainly by shale and sandstone bedrock with other types of bedrock present locally. The bedrock is overlain by till in much of the basin, but surficial deposits of saturated sand and gravel are present in some areas. Five of the wells sampled in the Delaware study area are completed in sand and gravel deposits, and five are completed in bedrock. Groundwater in the Delaware study area was typically neutral or slightly acidic; the water typically was soft. Bicarbonate, chloride, and calcium were the major ions with the greatest median concentrations; the dominant nutrient was nitrate. Strontium, barium, iron, and boron were the trace elements with the highest median concentrations. Radon was detected in all samples with activities greater than 300 picocuries per liter; the greatest radon activities were in samples from bedrock wells. Four pesticides, all herbicides or their degradates, were detected in four samples at trace levels; five VOCs, including four trihalomethanes and tetrachloromethane, were detected in two samples. Coliform bacteria were detected in five samples, but fecal coliform bacteria and Escherichia coli (E. coli) were not detected in any samples from the Delaware study area.

The St. Lawrence River Basin covers 5,650 square miles in New York. The St. Lawrence River Basin in New York is underlain by crystalline, carbonate, and sandstone bedrock. The bedrock is overlain by till or lacustrine and marine deposits in much of the basin. Surficial deposits of saturated sand and gravel are present locally, but most wells in the basin are completed in bedrock. Five of the wells sampled in the St. Lawrence study area are completed in sand and gravel deposits, and 15 are completed in bedrock. Groundwater in the St. Lawrence study area was typically neutral or slightly basic; the water typically was hard. Bicarbonate, sulfate, and calcium were the major ions with the greatest median concentrations; the dominant nutrient was nitrate. Strontium, iron, barium, and boron were the trace elements with the highest median concentrations. Radon was detected in two-thirds of samples with activities greater than 300 picocuries per liter; the greatest radon activities were in samples from bedrock wells. Seven pesticides, including 5 herbicides, an herbicide degradate, and an insecticide, were detected in 11 samples at trace levels; 3 VOCs (tetrachloroethene, toluene, and trichloromethane, or chloroform) were detected in 2 samples. Coliform bacteria were detected in 7 samples, and E. coli were detected in two samples in the St. Lawrence study area.

Water quality in both study areas is generally good, but concentrations of some constituents equaled or exceeded current or proposed Federal or New York State drinking-water standards. The standards exceeded are color (one sample in the St. Lawrence study area), $\mathrm{pH}$ (three samples in the Delaware study area), sodium (one sample in the St. Lawrence study area), total dissolved solids (one sample in the St. Lawrence study area), aluminum (one sample in the Delaware study area and one sample 
in the St. Lawrence study area), iron (seven samples in the St. Lawrence study area), manganese (one sample in the Delaware study area and five samples in the St. Lawrence study area), gross alpha radioactivity (one sample in the St. Lawrence study area), radon-222 (10 samples in the Delaware study area and 14 samples in the St. Lawrence study area), and bacteria (5 samples in the Delaware study area and 10 samples in the St. Lawrence study area). E. coli bacteria were detected in samples from two wells in the St. Lawrence study area. Concentrations of chloride, fluoride, sulfate, nitrate, nitrite, antimony, arsenic, barium, beryllium, cadmium, chromium, copper, lead, mercury, selenium, silver, thallium, zinc, and uranium did not exceed existing drinking-water standards in any of the samples collected.

\section{Introduction}

The Federal Clean Water Act Amendments of 1977 require biennial reports from states on the chemical quality of surface water and groundwater within their boundaries (U.S. Environmental Protection Agency, 1997). In 2002, the U.S. Geological Survey (USGS), in cooperation with the New York State Department of Environmental Conservation (NYSDEC), developed a program to evaluate groundwater quality throughout the major river basins in New York on a rotating basis. The program parallels the NYSDEC Rotating Intensive Basin Study program, which evaluates surface-water quality in 2 or 3 of the 14 major river basins in the State each year. The groundwater-quality program began in 2002 with a pilot study in the Mohawk River Basin and has continued throughout upstate New York since then (table 1). Sampling completed in 2008 represents the conclusion of a first round of groundwater-quality sampling throughout New York State (excluding Long Island, which is monitored through local county programs). Groundwater-quality sampling was conducted in 2010 in the Delaware, Genesee, and St. Lawrence River Basins; these basins also were sampled in 2005 as part of this study.

Table 1. Previous groundwater-quality studies and reports.

\begin{tabular}{|l|l|l|l|}
\hline \multicolumn{1}{|c|}{ Study area } & \multicolumn{1}{c|}{ Year } & \multicolumn{1}{c|}{ Report } & \multicolumn{1}{c|}{ Reference } \\
\hline Mohawk River Basin & 2002 & Water-Data Report NY-02-1 & Butch and others, 2003 \\
\hline Chemung River Basin & 2003 & Open-File Report 2004-1329 & Hetcher-Aguila, 2005 \\
\hline Lake Champlain Basin & 2004 & Open-File Report 2006-1088 & Nystrom, 2006 \\
\hline Susquehanna River Basin & 2004 & Open-File Report 2006-1161 & Hetcher-Aguila and Eckhardt, 2006 \\
\hline Delaware River Basin & 2005 & Open-File Report 2007-1098 & Nystrom, 2007b \\
\hline Genesee River Basin & 2005 & Open-File Report 2007-1093 & Eckhardt and others, 2007 \\
\hline St. Lawrence River Basin & 2005 & Open-File Report 2007-1066 & Nystrom, 2007a \\
\hline Mohawk River Basin & 2006 & Open-File Report 2008-1086 & Nystrom, 2008 \\
\hline Western New York & 2006 & Open-File Report 2008-1140 & Eckhardt and others, 2008 \\
\hline Central New York & 2007 & Open-File Report 2009-1257 & Eckhardt and others, 2009 \\
\hline Upper Hudson River Basin & 2007 & Open-File Report 2009-1240 & Nystrom, 2009 \\
\hline Chemung River Basin & 2008 & Open-File Report 2011-1112 & Risen and Reddy, 2011a \\
\hline Eastern Lake Ontario Basin & 2008 & Open-File Report 2011-1074 & Risen and Reddy, 2011b \\
\hline Lower Hudson River Basin & 2008 & Open-File Report 2010-1197 & Nystrom, 2010 \\
\hline Lake Champlain Basin & 2009 & Open-File Report 2011-1180 & Nystrom, 2011 \\
\hline Susquehanna River Basin & 2009 & & \\
\hline
\end{tabular}

\section{Purpose and Scope}

This report presents the findings of the 2010 study in the Delaware River Basin, in which 10 groundwater-quality samples were collected from August through November 2010, and in the St. Lawrence River Basin, in which 20 groundwater-quality samples were collected from August through October 2010. The report (1) describes the hydrogeologic setting, sampled wells, and the methods of site selection, sample collection, and chemical analysis, (2) presents discussions of the analytical results for physiochemical properties and concentrations of major ions, nutrients, trace elements, pesticides, volatile organic compounds (VOCs), radionuclides, and indicator bacteria, and (3) presents comparisons of the 
results of this study with results for selected wells in the Delaware and St. Lawrence River Basins that were sampled in 2005 (Nystrom, 2007a and 2007b).

\section{Hydrogeologic Setting of the Delaware River Basin in New York}

The Delaware River Basin encompasses approximately 12,700 square miles ( $\mathrm{mi}^{2}$ ) in New York, Pennsylvania, New Jersey, and Delaware. This study addressed the 2,360- $\mathrm{mi}^{2}$ part of the Delaware River Basin that lies within New York (hereafter referred to as the "Delaware study area"; fig. 1). The Delaware study area contains parts of eight counties, including most of Delaware and Sullivan Counties, part of Broome, Orange, and Ulster Counties, and small parts of Chenango, Greene, and Schoharie Counties (fig. 1).
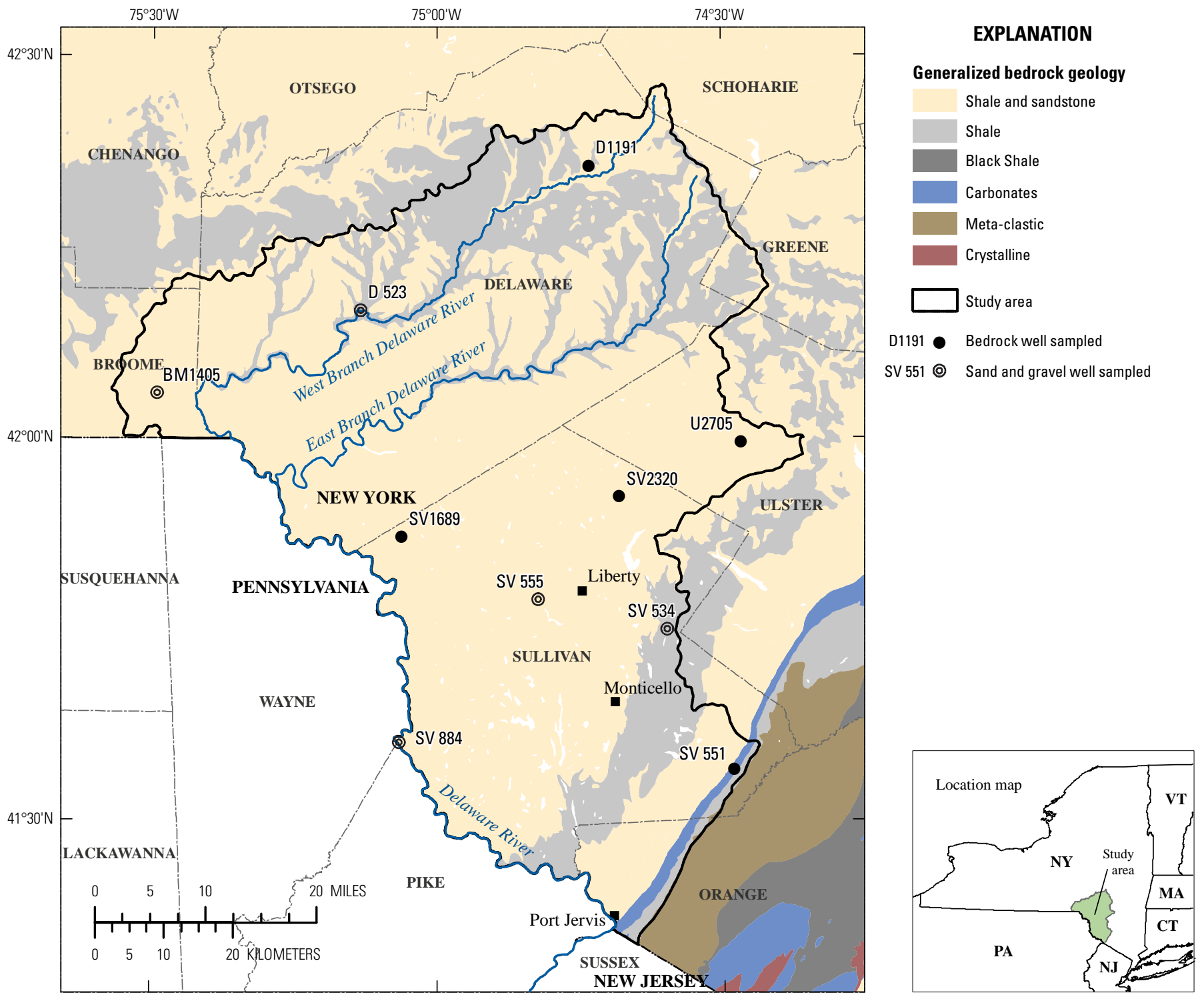

Base from U.S. geological Survey digital data, 1983, 1:100,000 Universal Transverse Mercator projection

Geology modified from Fisher and others, 1970

Figure 1. Generalized bedrock geology of the Delaware River Basin, New York, and locations of wells sampled in 2010. 
The highest elevations in the Delaware study area are more than 4,000 ft above the North American Vertical Datum of 1988 (NAVD 88) along the eastern edge of the basin; the lowest elevation (approximately $420 \mathrm{ft}$ ) in the basin is at the Delaware River's exit from New York State at Port Jervis (fig. 1). The Delaware study area is predominantly forested, especially in upland areas, with urban and agricultural areas mainly in valleys and other low-lying areas (Vogelmann and others, 2001). Urban centers and adjacent developed areas in the Delaware study area include Port Jervis, Monticello, and Liberty (fig. 1).
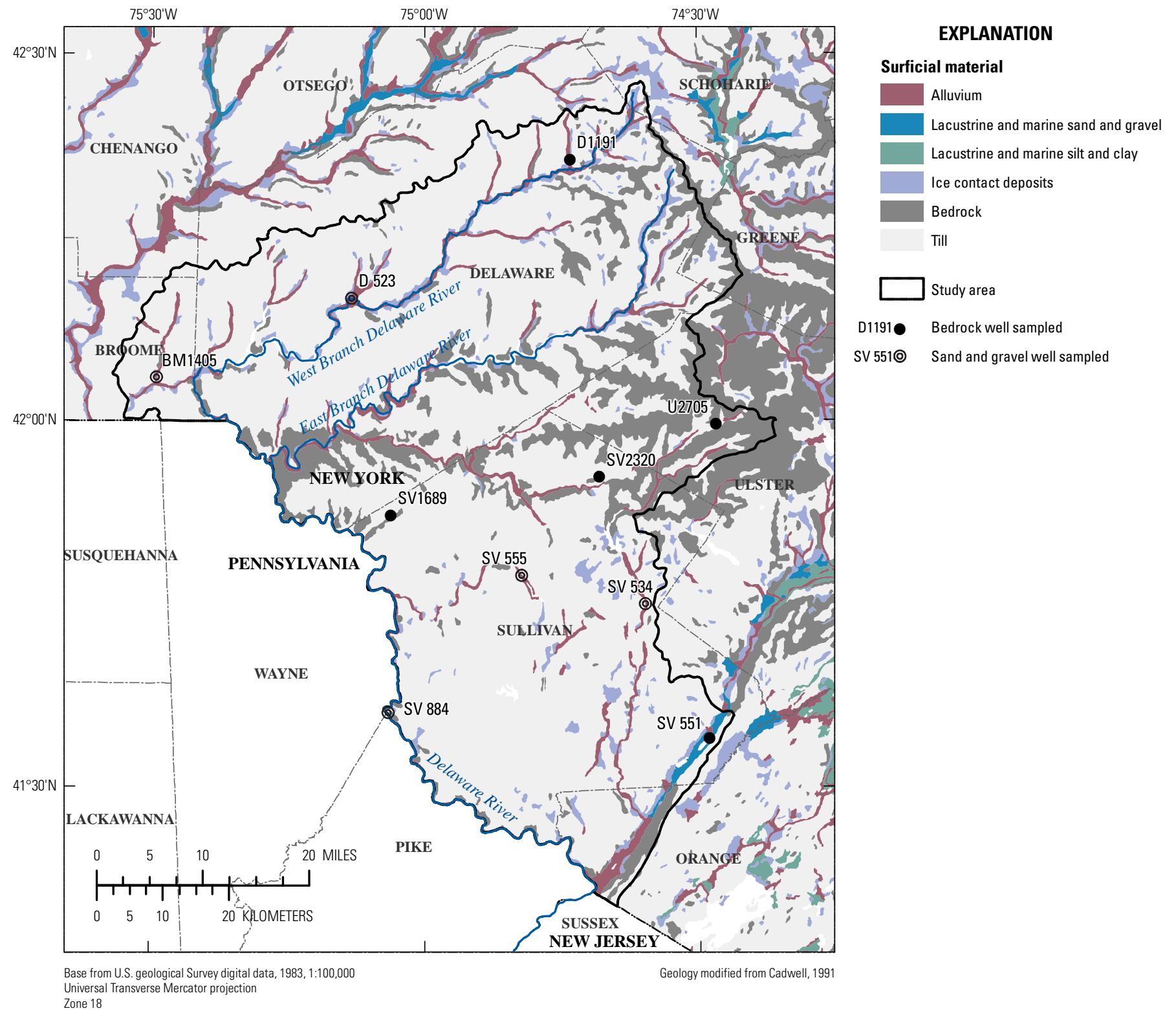

Figure 2. Generalized surficial geology of the Delaware River Basin, New York, and locations of wells sampled in 2010.

Bedrock in the Delaware study area (fig. 1) is mainly sedimentary sandstone and shale with a narrow (less than $10 \mathrm{mi}$ wide) band of carbonate rocks that runs parallel to the southeastern edge of the basin. Wells completed in the sandstone and shale generally produce small to moderate yields of 10 to $100 \mathrm{gal} / \mathrm{min}$ (Barksdale, 1970). The surficial material (fig. 2) throughout the study area was deposited 
primarily during the Pleistocene epoch when the Wisconsin glaciers covered most of the Northeast (Isachsen and others, 2000). Till was deposited by glaciers over most of the study area; alluvial, glaciofluvial, and ice-contact sand and gravel deposits are present mainly in valleys. Till generally has low yields of water, whereas the well sorted valley deposits form important aquifers in the basin that may produce yields of 1,000 gal/min or more (Barksdale, 1970).

\section{Hydrogeologic Setting of the St. Lawrence River Basin in New York}

The St. Lawrence River forms the outlet of the Great Lakes Basin, the largest fresh surface-water system in the world (Government of Canada and U.S. Environmental Protection Agency, 1995), draining 296,000 $\mathrm{mi}^{2}$ in the United States and Canada. This study addressed the 5,650- $\mathrm{mi}^{2}$ part of the St. Lawrence River Basin that lies downstream from Lake Ontario within New York (hereafter referred to as the "St. Lawrence study area”), excluding the Lake Champlain/Richelieu River Basin (fig. 3). The St. Lawrence study area contains all or part of eight counties, including all of St. Lawrence County, most of Franklin County, and portions of Clinton, Essex, Hamilton, Herkimer, Jefferson, and Lewis Counties (fig. 3). The highest elevations in the St. Lawrence study area are more than 4,000 ft above NAVD 88 along the southeastern edge of the basin in the Adirondack Mountains (fig. 3); the lowest elevations (approximately $150 \mathrm{ft}$ ) are present along the northern edge of the study area in the St. Lawrence Valley. The portion of the St. Lawrence study area in the Adirondack Mountains is predominantly forested; agricultural and urban areas in the study area are present mainly in the St. Lawrence Valley (Vogelmann and others, 2001).

Bedrock in the St. Lawrence study area (fig. 3) is mainly crystalline, but two wide bands of carbonate and sandstone bedrock are present along the northern edge of the basin. The surficial material (fig. 4) throughout the study area was deposited primarily during the Pleistocene epoch when the Wisconsin glaciers covered most of the Northeast (Isachsen and others, 2000). Till was deposited by glaciers over much of the study area, but large lacustrine and marine deposits are present, especially in the western part of the study area. Alluvial, glaciofluvial, and ice-contact sand and gravel deposits are present mainly in valleys. Sand and gravel deposits generally produce the highest yields in the St. Lawrence study area, but the sandstone and carbonate aquifers along the northern edge of the basin in the St. Lawrence Valley (fig. 3) also produce moderate yields (Great Lakes Basin Commission, 1975). The crystalline bedrock in the Adirondack Mountains generally produces the lowest yields of the aquifers in the basin. Most wells in the St. Lawrence study area are completed in bedrock; production wells are completed in sand and gravel deposits where they are present.

\section{Methods of Investigation}

The methods used in this study, including (1) well-selection criteria, (2) sampling methods, and (3) analytical methods, were designed to maximize data precision, accuracy, and comparability.

Groundwater-sample collection and processing followed standard USGS procedures as documented in the National Field Manual for the Collection of Water-Quality Data (U.S. Geological Survey, variously dated). Samples were analyzed by documented methods at the USGS National Water Quality Laboratory (NWQL) in Denver, CO, and other laboratories.

\section{Well Selection}

Wells were selected to provide adequate spatial coverage of the study area with emphasis on areas of greatest groundwater use. The final selection of each well was based on the availability of wellconstruction data and hydrogeologic information for the well and its surrounding area. The study did not target specific municipalities, industries, or agricultural practices. The 30 wells selected for sampling (figs. 1 to 4) represent forested, developed, and agricultural areas. The characteristics of the wells sampled and the type of land cover surrounding each well are listed in tables 2 (Delaware study area) and 3 (St. Lawrence study area). The depths of the wells, the geologic units from which samples were 
collected, and the numbers of production and domestic wells are summarized in tables 4 and 5 . Five wells sampled in 2010 (one well, SV1689, in the Delaware study area and four wells, F543, F573, ST378, and ST950, in the St. Lawrence study area) were also sampled in 2005 (Nystrom, 2007a and 2007b).

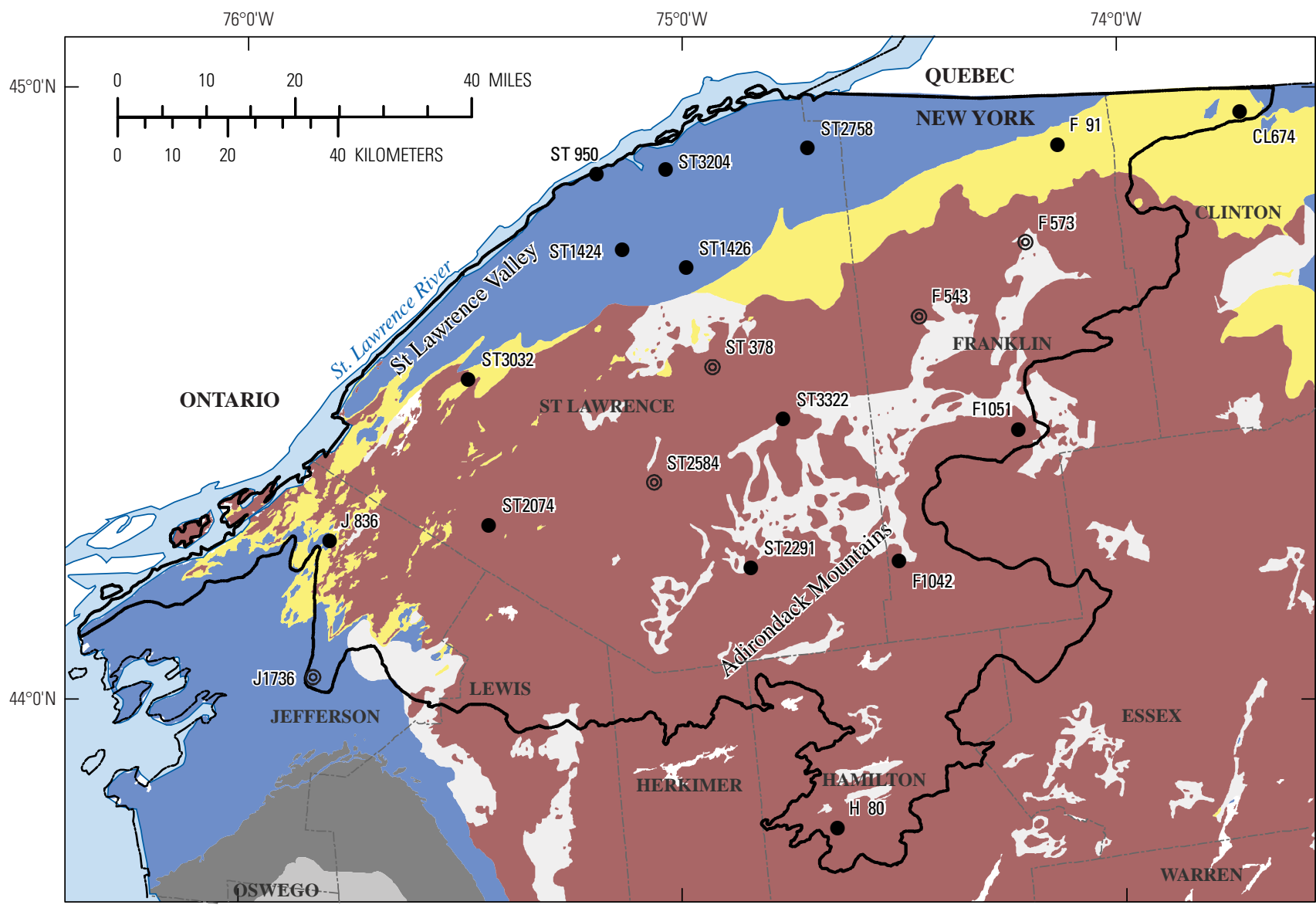

Base from U.S. geological Survey digital data, 1983, 1:100,000

Geology modified from Fisher and others, 1970 Zone 18

\section{EXPLANATION}

Generalized bedrock geology
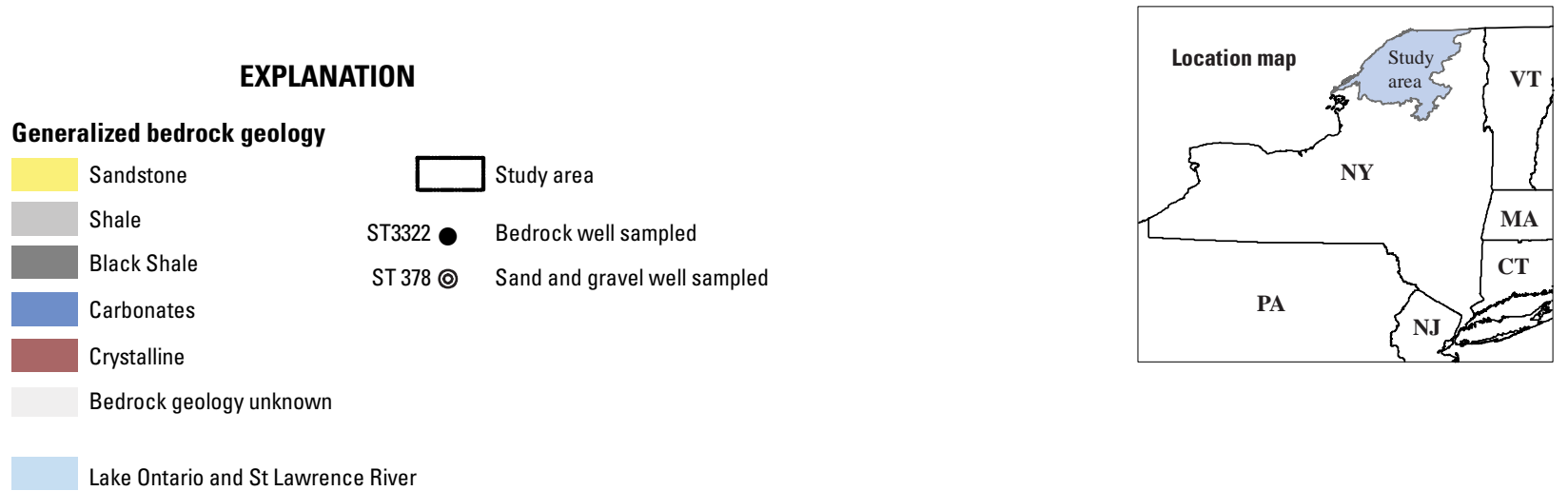

Figure 3. Generalized bedrock geology of the St. Lawrence River Basin, New York, and locations of wells sampled in 2010. 


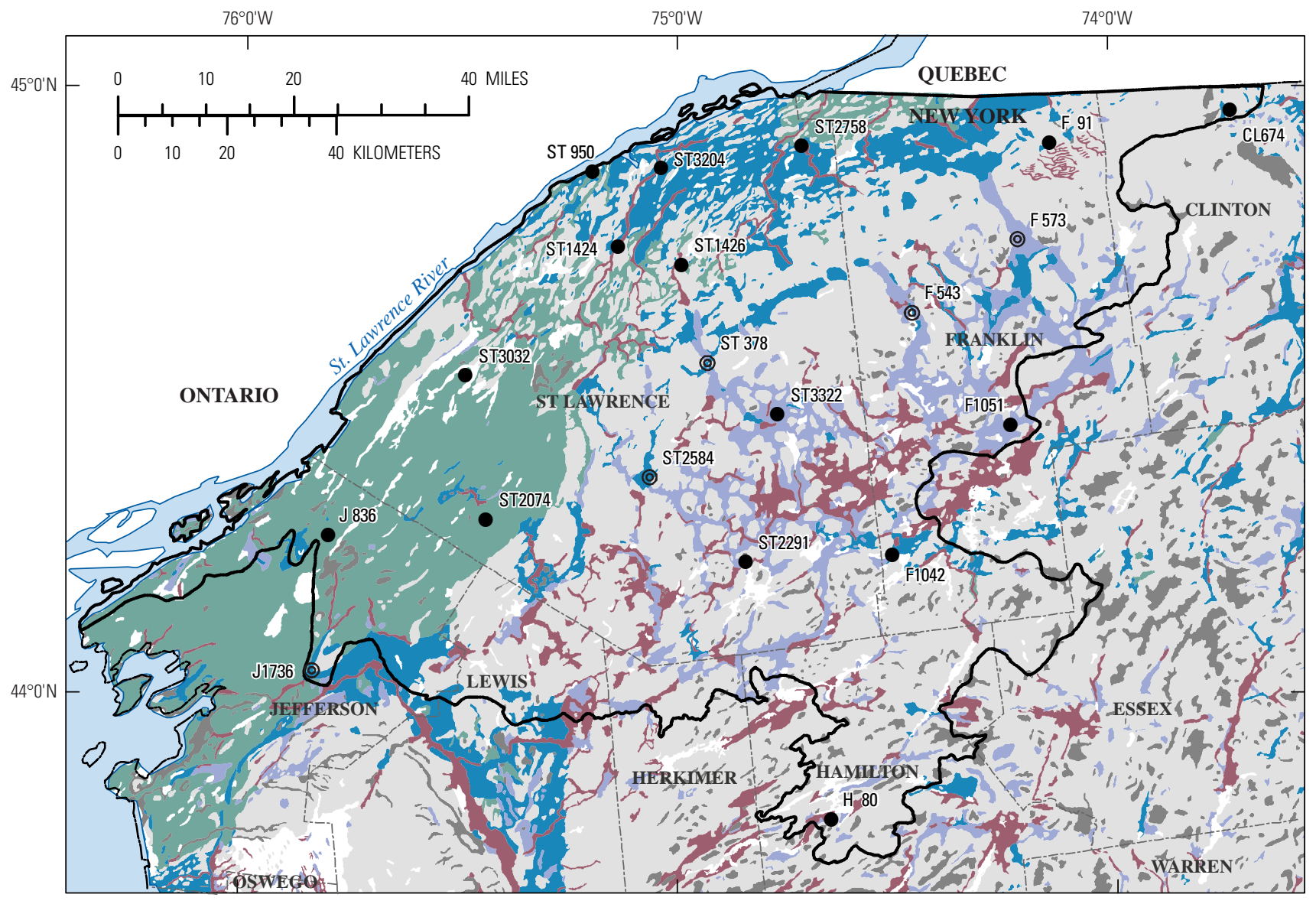

Base from U.S. geological Survey digital data, 1983, 1:100,000 Universal Transverse Mercator projection

Zone 18

\section{EXPLANATION}

\section{Surficial material}
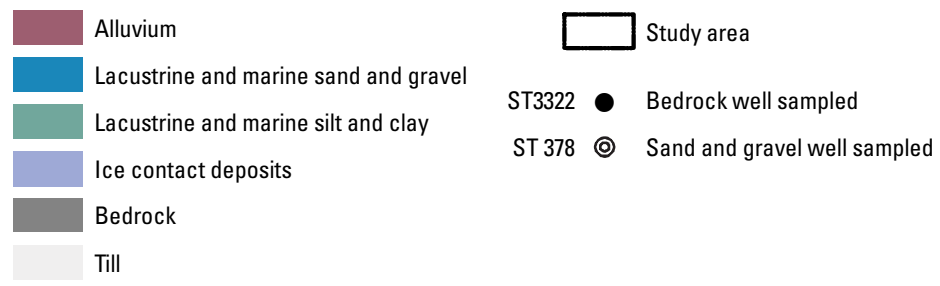

Lake Ontario and St Lawrence River

Figure 4. Generalized surficial geology of the St. Lawrence River Basin, New York, and locations of wells sampled in 2010.

The domestic wells were selected on the basis of information from the NYSDEC Water Well program, which began in 2000. The program requires that licensed well drillers file a report with NYSDEC containing basic information about each well drilled, such as well and casing depth, diameter, yield, and a hydrogeologic log. Inspection of well-completion reports identified about 450 wells as potential sampling sites. The well owners were each sent a letter that included a request for permission to sample the well and a questionnaire about the well. Well owners who granted permission were contacted later by phone to verify well information and to arrange a convenient time for sampling. 
Production wells considered for sampling were identified through the U.S. Environmental Protection Agency (USEPA) Safe Drinking Water Information System and the NYSDEC Water Well program. Town officials and (or) water managers were sent letters requesting permission to sample a well, and follow-up phone calls were made to arrange a time for sampling. Well information, such as depth, was provided by water managers if a well-completion report was unavailable. The aquifer type indicated for sampled wells was verified through inspection of published geologic maps, including Fisher and others (1970) and Cadwell (1991)

\section{Sample Collection and Analytical Methods}

Samples were collected and processed in accordance with documented USGS protocols (U.S. Geological Survey, variously dated). The samples were collected before any water-treatment system to be as representative of the aquifer water quality as possible. Most samples from domestic wells were collected from a spigot near the pressure tank; samples from production wells were collected at the spigot or faucet used for collection of raw-water samples by water managers. Detailed sample collection methods are documented in Nystrom (2010).

Samples were analyzed for 147 physiochemical properties and constituents, including major ions, nutrients, trace elements, pesticides and pesticide degradates, VOCs, radionuclides, and bacteria. Physiochemical properties such as water temperature, $\mathrm{pH}$, dissolved oxygen concentration, and specific conductance were measured at the sampling site. Major ions, nutrients, total organic carbon, trace elements, radon-222, pesticides and pesticide degradates, and VOCs were analyzed at the USGS NWQL in Denver, CO. Selected dissolved gases were measured at the USGS Chlorofluorocarbon Laboratory (CFCL) in Reston, VA. Gross alpha and gross beta radioactivities were measured at Eberline Services in Richmond, CA. Indicator bacteria were analyzed at the New York State Department of Health (NYSDOH) certified OCL Analytical Services, in Bloomingburg, NY and Life Science Laboratories in Waddington, NY. More information about the analytical methods used can be found in Nystrom (2010).

Table 2. Information on wells from which water samples were collected in the Delaware River Basin, New York, 2010. [--, unknown; well types: P, production; D, domestic. Land cover categories: D, $\square$ developed; F, $\square$ forested;

A, $\square$ agricultural; W, $\square$ open water; WL, $\square$ wetlands. Well locations are shown in figures 1 and 2]

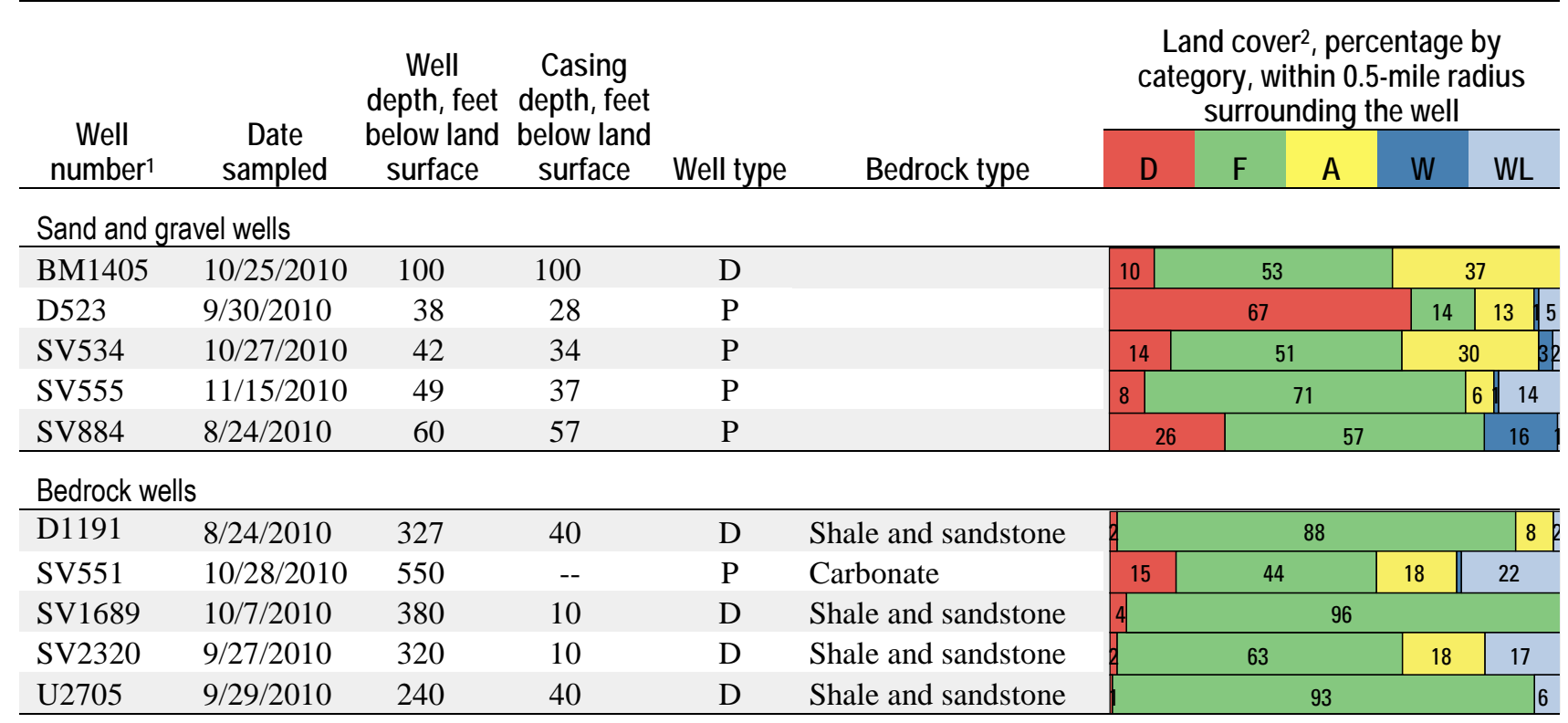

\footnotetext{
${ }^{1}$ BM, Broome County; D, Delaware County; SV, Sullivan County; U, Ulster County.
}

${ }^{2}$ Determined from the National Land Cover Data set (Vogelmann and others, 2001). 


\section{Quality Control Samples}

In addition to the 30 groundwater samples, 1 blank sample and 2 concurrent replicate samples were collected for quality assurance. No constituents exceeded laboratory reporting levels (LRLs) in the blank sample. The variability between replicate samples was greatest for unfiltered trace elements. The only VOC or pesticide detected in the replicate samples was simazine, which was detected in samples from one well at a concentration of 0.003 micrograms per liter $(\mu \mathrm{g} / \mathrm{L})$ in the regular sample and $0.004 \mu \mathrm{g} / \mathrm{L}$ in the replicate sample.

Table 3. Information on wells from which water samples were collected in the St. Lawrence River Basin, New York, 2010.

[--, unknown; well types: P, production; D, domestic; M, municipal. Land cover categories: D, $\square$ developed; F, $\square$ forested; A, $\square$ agricultural; W, $\square$ open water; WL, $\square$ wetlands. Well locations are shown in figures 3 and 4]

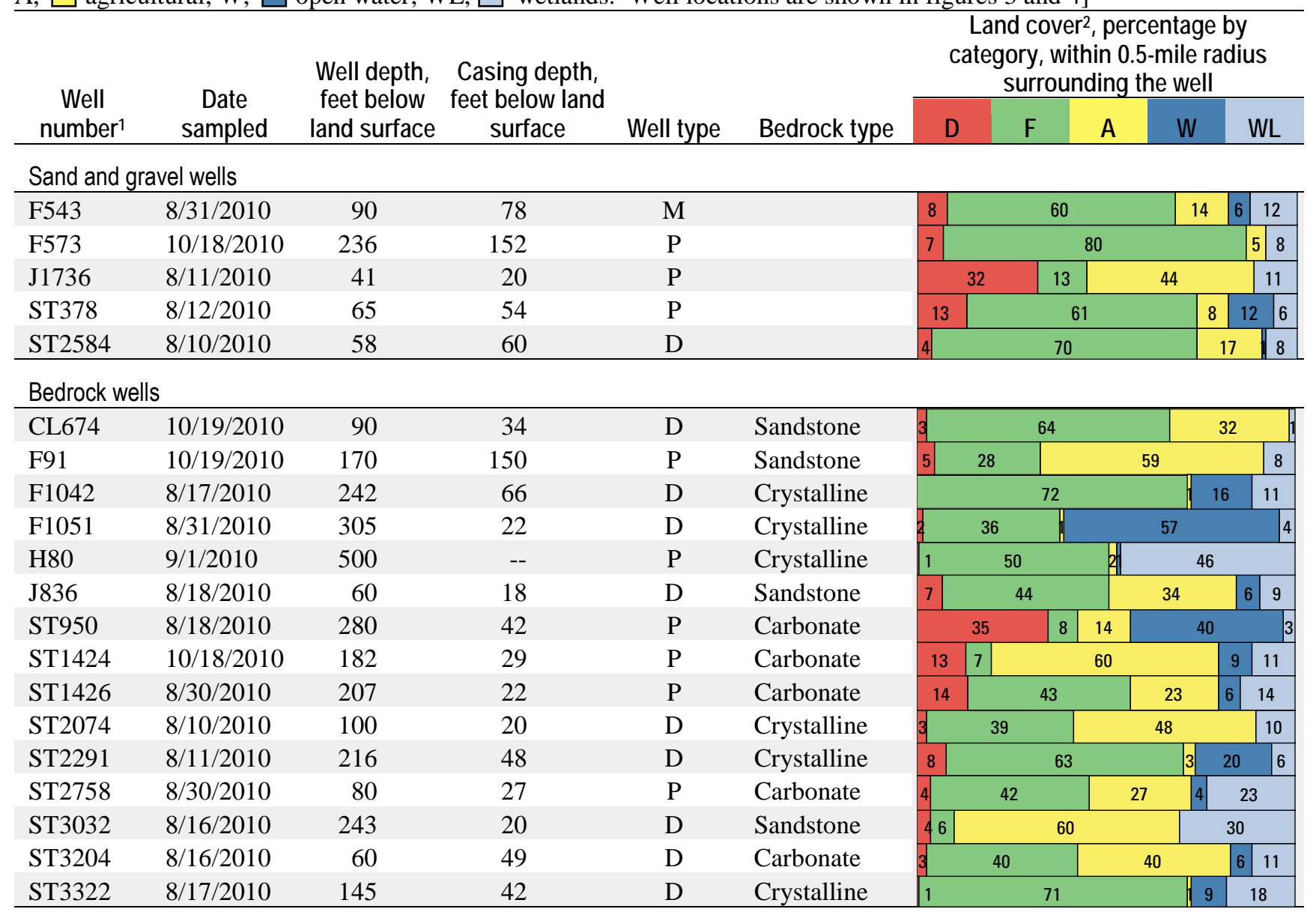

${ }^{1}$ CL, Clinton County; F, Franklin County; H, Hamilton County; J, Jefferson County; ST, St. Lawrence County.

${ }^{2}$ Determined from the National Land Cover Data set (Vogelmann and others, 2001) 
Table 4. Summary of information on wells from which water samples were collected in the Delaware River Basin, New York, 2010.

[bls, below land surface]

\begin{tabular}{l|c|c|c}
\hline \multicolumn{1}{c}{ Type of well } & 4 & Number of wells \\
\cline { 2 - 4 } Wells completed in sand and gravel (depth 38 to 100 feet bls) & Production & Domestic & Total \\
\hline Wells completed in bedrock (depth 240 to 550 feet bls) & 1 & 5 \\
\hline Carbonate bedrock & 1 & 4 & 5 \\
\hline Shale and sandstone bedrock & 0 & 0 & 1 \\
\hline Total number of wells & 5 & 5 & 10 \\
\hline
\end{tabular}

Table 5. Summary of information on wells from which water samples were collected in the St. Lawrence River Basin, New York, 2010.

[bls, below land surface]

\begin{tabular}{cc|c|r}
\hline \multicolumn{1}{c}{ Type of well } & \multicolumn{3}{c}{ Number of wells } \\
\cline { 2 - 4 } & $\begin{array}{c}\text { Production \& } \\
\text { municipal }\end{array}$ & Domestic & Total \\
\hline Wells completed in sand and gravel (depth 41 to 236 feet bls) & 4 & 1 & 5 \\
\hline Wells completed in bedrock (depth 60 to 500 feet bls) & 6 & 9 & 15 \\
\hline Carbonate bedrock & 4 & 1 & 5 \\
Sandstone bedrock & 1 & 3 & 4 \\
Crystalline bedrock & 1 & 5 & 6 \\
\hline Total number of wells & 10 & 10 & 20 \\
\hline
\end{tabular}

\section{Groundwater Quality}

Many of the constituents for which the groundwater samples were analyzed were not detected in any sample. Some concentrations are reported as "estimated." Estimated concentrations are typically reported when the detected value is less than the established LRL or when recovery of a compound has been shown to be highly variable (Childress and others, 1999). Concentrations of some constituents exceeded maximum contaminant levels (MCLs) or secondary drinking-water standards (SDWS) set by the USEPA (U.S. Environmental Protection Agency, 2009) or NYSDOH (New York State Department of Health, 2007). MCLs are enforceable standards for finished water in public water supplies; they are not enforceable for private homeowner wells but are presented here as a standard for evaluation of the waterquality results. SDWS are nonenforceable drinking-water standards that typically relate to aesthetic concerns such as taste, odor, or staining of plumbing fixtures.

\section{Groundwater Quality in the Delaware River Basin, New York}

The results of analyses of the 10 groundwater samples collected in the Delaware study area during August through November 2010 are presented in tables 1-1 through 1-9 in appendix 1. Of the 147 constituents and physiochemical properties analyzed for, 79 were not detected at levels greater than the LRLs in samples from the Delaware study area (appendix table 1-1). Results for the remaining 68 constituents and properties that were detected in the Delaware study area are presented in appendix 1, tables 1-2 through 1-9. 


\section{Physiochemical Properties}

All of the samples from the Delaware study area had a color of less than $(<) 1$ platinum-cobalt (PtCo) unit (table 6 and appendix table 1-2), and none exceeded the NYSDOH MCL and USEPA SDWS of $15 \mathrm{Pt}-\mathrm{Co}$ units. Dissolved oxygen concentration ranged from $<0.3$ to more than $9.6 \mathrm{mg} / \mathrm{L}$. Sample $\mathrm{pH}$ was typically near neutral or slightly acidic (median 6.6 for all wells) and ranged from 5.6 to 7.7. The pH of four samples was lower than the USEPA SDWS range for $\mathrm{pH}$ (6.5 to 8.5); two of the samples were from sand and gravel wells, and one was from a bedrock well. Specific conductance ranged from 44 to 375 microsiemens per centimeter at 25 degrees Celsius $\left(\mu \mathrm{S} / \mathrm{cm}\right.$ at $\left.25^{\circ} \mathrm{C}\right)$; the median conductance was 216 $\mu \mathrm{S} / \mathrm{cm}$ at $25^{\circ} \mathrm{C}$. Water temperature ranged from 8.2 to $14.9^{\circ} \mathrm{C}$; the median temperature was $10.4^{\circ} \mathrm{C}$. Methane was detected in 4 of the 10 samples with a maximum concentration of $0.014 \mathrm{mg} / \mathrm{L}$.

Table 6. Drinking-water standards and summary statistics for physiochemical properties of groundwater samples from the Delaware River Basin, New York, 2010.

[All concentrations in unfiltered water except as noted; Pt-Co units, platinum-cobalt units; mg/L, milligrams per liter; $\mu \mathrm{S} / \mathrm{cm}$, microsiemens per centimeter at 25 degrees Celsius; ${ }^{\circ} \mathrm{C}$, degrees Celsius; --, not applicable; <, less than; E, estimated concentration]

\begin{tabular}{|c|c|c|c|c|c|c|c|c|c|}
\hline \multirow[b]{3}{*}{ Constituent } & \multicolumn{9}{|c|}{ Summary statistics and concentrations } \\
\hline & \multirow{2}{*}{$\begin{array}{l}\text { Drinking- } \\
\text { water } \\
\text { standard }\end{array}$} & \multirow{2}{*}{$\begin{array}{l}\text { Number of } \\
\text { samples } \\
\text { exceeding } \\
\text { standard }\end{array}$} & \multirow{2}{*}{$\begin{array}{c}\text { Median } \\
\text { (all } \\
\text { samples) }\end{array}$} & \multicolumn{3}{|c|}{$\begin{array}{c}\text { Sand and gravel aquifers } \\
\text { (5 samples) }\end{array}$} & \multicolumn{3}{|c|}{$\begin{array}{c}\text { Bedrock aquifers } \\
\text { (5 samples) }\end{array}$} \\
\hline & & & & Minimum & Median & Maximum & Minimum & Median & Maximum \\
\hline Color, filtered, Pt-Co units & ${ }^{1} 15$ & 0 & $<1$ & $<1$ & $<1$ & $<1$ & $<1$ & $<1$ & $<1$ \\
\hline Carbon dioxide, mg/L & -- & -- & 25.2 & 4.7 & 31.0 & 76.5 & 2.4 & 23.2 & 32.1 \\
\hline Dissolved oxygen, mg/L & -- & -- & 5.6 & .5 & 1.6 & 7.2 & $<.3$ & 7.2 & 9.6 \\
\hline $\mathrm{pH}$ & ${ }^{1} 6.5-8.5$ & 4 & 6.6 & 5.6 & 6.5 & 7.6 & 5.6 & 6.8 & 7.7 \\
\hline Specific conductance, $\mu \mathrm{S} / \mathrm{cm}$ & -- & -- & 216 & 176 & 278 & 355 & 44 & 99 & 375 \\
\hline Temperature, ${ }^{\circ} \mathrm{C}$ & -- & -- & 10.4 & 9.3 & 11.6 & 14.9 & 8.2 & 9.7 & 12.6 \\
\hline Argon, mg/L & -- & -- & .7145 & .5759 & .7115 & .7739 & .6763 & .7175 & .8252 \\
\hline Nitrogen gas, mg/L & -- & -- & 19.65 & 16.05 & 19.92 & 22.39 & 17.37 & 19.38 & 23.88 \\
\hline Methane, mg/L & -- & -- & $<.0005$ & $<.0005$ & E.0002 & .0010 & $<.0005$ & $<.0005$ & .014 \\
\hline
\end{tabular}

${ }^{1}$ U.S. Environmental Protection Agency Secondary Drinking Water Standard.

\section{Major lons}

The anions detected in the highest concentrations were bicarbonate (median concentration 66 mg/L, maximum concentration $122 \mathrm{mg} / \mathrm{L}$ ) and chloride (median concentration $22.2 \mathrm{mg} / \mathrm{L}$, maximum concentration $52.3 \mathrm{mg} / \mathrm{L}$ ) (table 7 and appendix table 1-3). The cation detected in the highest concentration was calcium (median concentration $17.0 \mathrm{mg} / \mathrm{L}$, maximum concentration $44.6 \mathrm{mg} / \mathrm{L}$ ). The median concentrations of most major ions were greater in samples from sand and gravel wells than in samples from bedrock wells, especially chloride (median $31.5 \mathrm{mg} / \mathrm{L}$ in sand and gravel wells and 4.08 $\mathrm{mg} / \mathrm{L}$ in bedrock wells) and sodium (19.3 mg/L in sand and gravel wells and $3.60 \mathrm{mg} / \mathrm{L}$ in bedrock wells). Water samples from the Delaware study area were generally soft (0 to $60 \mathrm{mg} / \mathrm{L}$ as $\mathrm{CaCO}_{3} ; \mathrm{Hem}$, 1985) with a median hardness of $56.4 \mathrm{mg} / \mathrm{L}$ as $\mathrm{CaCO}_{3}$. Five samples were soft ( 0 to $60 \mathrm{mg} / \mathrm{L}$ as $\mathrm{CaCO}_{3}$ ), three samples were moderately hard (61 to $120 \mathrm{mg} / \mathrm{L}$ as $\mathrm{CaCO}_{3}$ ), and two samples were hard (121 to $180 \mathrm{mg} / \mathrm{L}$ as $\mathrm{CaCO}_{3}$ ). Alkalinity ranged from 9 to $100 \mathrm{mg} / \mathrm{L}$ as $\mathrm{CaCO}_{3}$; the median was $54 \mathrm{mg} / \mathrm{L}$ of $\mathrm{CaCO}_{3}$. Dissolved solids ranged from 34 to $235 \mathrm{mg} / \mathrm{L}$ with a median of $128 \mathrm{mg} / \mathrm{L}$. The concentrations of sodium, chloride, fluoride, sulfate, and dissolved solids did not exceed established MCLs in any sample (table 7). 
Table 7. Drinking-water standards and summary statistics for concentrations of major ions in groundwater samples from the Delaware River Basin, New York, 2010.

[All concentrations are in milligrams per liter in filtered water; --, not applicable; <, less than; ${ }^{\circ} \mathrm{C}$, degrees Celsius; $\mathrm{CaCO}$, calcium carbonate]

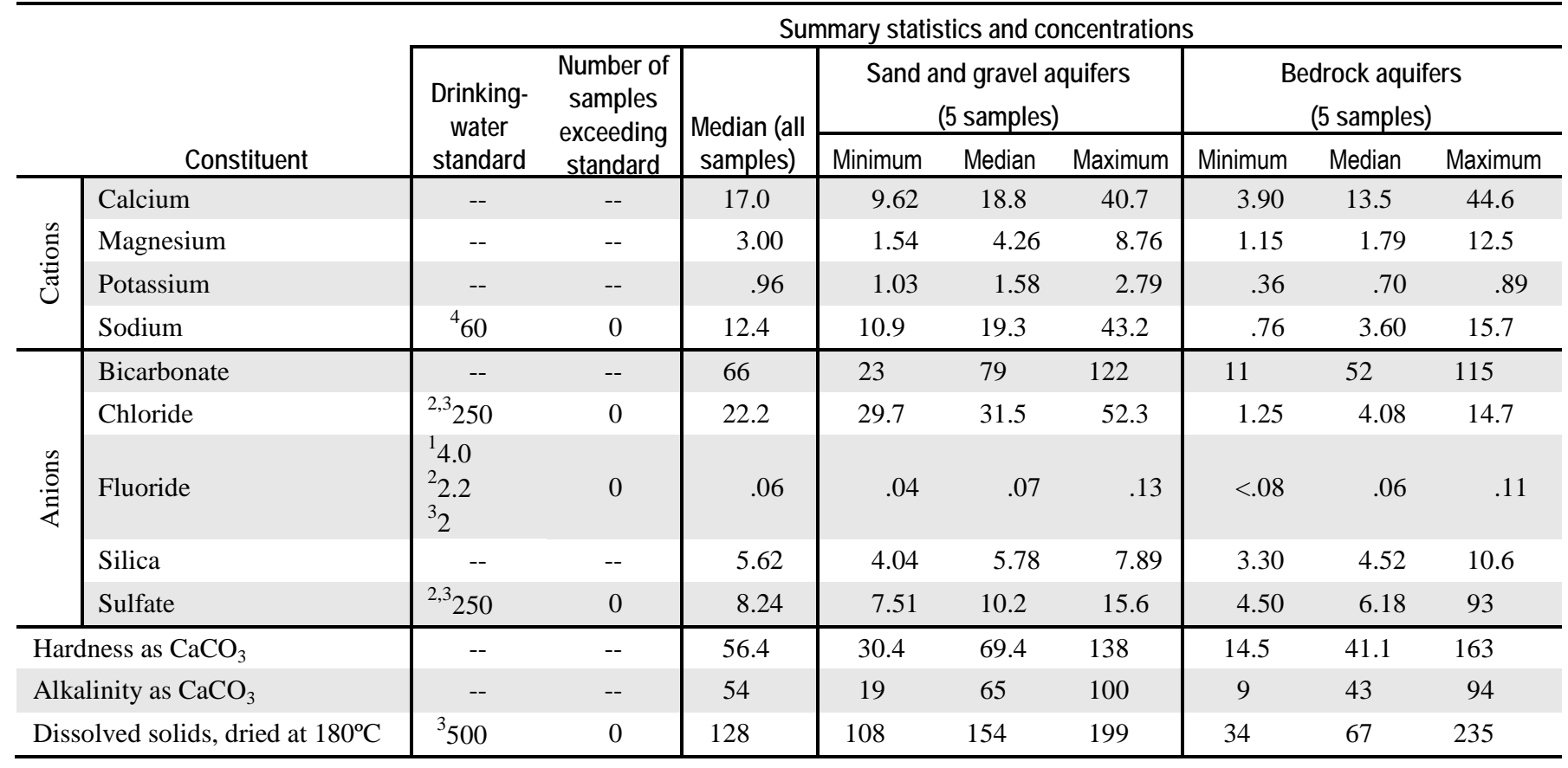

${ }^{1}$ U.S. Environmental Protection Agency Maximum Contaminant Level.

${ }^{2}$ New York State Department of Health Maximum Contaminant Level.

${ }^{3}$ U.S. Environmental Protection Agency Secondary Drinking Water Standard.

${ }^{4}$ U.S. Environmental Protection Agency Drinking Water Advisory Taste Threshold.

\section{Nutrients and Total Organic Carbon}

The dominant nutrient detected in the Delaware study area was nitrate (table 8 and appendix table 1-4). Concentrations of ammonia ranged from $<0.010$ to $0.046 \mathrm{mg} / \mathrm{L}$ as nitrogen $(\mathrm{N})$. Concentrations of nitrite plus nitrate ranged from $<0.04$ to $1.54 \mathrm{mg} / \mathrm{L}$ as $\mathrm{N}$; the median concentration was $0.55 \mathrm{mg} / \mathrm{L}$ as $\mathrm{N}$. The concentration of nitrate plus nitrite did not exceed the USEPA and NYSDOH MCL of $10 \mathrm{mg} / \mathrm{L}$ as N in any sample. Nitrite was detected in two samples with a maximum concentration of $0.009 \mathrm{mg} / \mathrm{L}$ as $\mathrm{N}$; the concentration of nitrite did not exceed the MCL $(1 \mathrm{mg} / \mathrm{L}$ as $\mathrm{N})$ in any sample. Orthophosphate concentrations ranged from 0.009 to $0.038 \mathrm{mg} / \mathrm{L}$ as phosphorus $(\mathrm{P})$. Total organic carbon was detected in 9 of the 10 samples; the maximum concentration was $1.2 \mathrm{mg} / \mathrm{L}$. 
Table 8. Drinking-water standards and summary statistics for concentrations of nutrients in groundwater samples from the Delaware River Basin, New York, 2010.

[All concentrations in milligrams per liter in filtered water except as noted. N, nitrogen; P, phosphorus; --, not applicable; <, less than; E, estimated concentration]

\begin{tabular}{|c|c|c|c|c|c|c|c|c|c|}
\hline \multirow{2}{*}{ Constituent } & \multicolumn{9}{|c|}{ Summary statistics and concentrations } \\
\hline & $\begin{array}{l}\text { Drinking- } \\
\text { water } \\
\text { standard }\end{array}$ & $\begin{array}{l}\text { Number of } \\
\text { samples } \\
\text { exceeding } \\
\text { standard }\end{array}$ & $\begin{array}{c}\text { Median } \\
\text { (all } \\
\text { samples) }\end{array}$ & \multicolumn{3}{|c|}{$\begin{array}{c}\text { Sand and gravel aquifers } \\
\text { (5 samples) }\end{array}$} & \multicolumn{3}{|c|}{$\begin{array}{c}\text { Bedrock aquifers } \\
\text { (5 samples) }\end{array}$} \\
\hline $\begin{array}{l}\text { Ammonia plus organic } \\
\mathrm{N} \text {, as } \mathrm{N}\end{array}$ & -- & -- & $<0.10$ & $<0.05$ & $<0.10$ & 0.08 & $<0.05$ & $<0.10$ & 0.12 \\
\hline Ammonia $\left(\mathrm{NH}_{3}\right)$, as $\mathrm{N}$ & -- & -- & $<.020$ & $<.010$ & $<.010$ & $<.020$ & $<.010$ & $<.020$ & .046 \\
\hline Nitrite $\left(\mathrm{NO}_{2}\right)$, as $\mathrm{N}$ & 1,21 & 0 & $<.002$ & $<.001$ & $<.002$ & .009 & $<.001$ & $<.002$ & .004 \\
\hline $\begin{array}{l}\text { Orthophosphate }\left(\mathrm{PO}_{4}\right) \text {, as } \\
\text { P }\end{array}$ & -- & -- & .016 & .010 & .019 & .034 & .009 & .013 & .038 \\
\hline $\begin{array}{l}\text { Total organic carbon } \\
\text { (TOC), unfiltered }\end{array}$ & -- & -- & E.6 & $<.3$ & .4 & 1 & E.4 & 6 & 1.2 \\
\hline
\end{tabular}

${ }^{1}$ U.S. Environmental Protection Agency Maximum Contaminant Level.

${ }^{2}$ New York State Department of Health Maximum Contaminant Level.

\section{Trace Elements}

The trace elements present in the highest median concentrations in the samples were strontium (median $124 \mu \mathrm{g} / \mathrm{L}$ ), barium (median $46.3 \mu \mathrm{g} / \mathrm{L}$ ), iron (median $28 \mu \mathrm{g} / \mathrm{L}$ in unfiltered water; $4 \mu \mathrm{g} / \mathrm{L}$ estimated in filtered water), and boron (median $17 \mu \mathrm{g} / \mathrm{L}$ ) (table 9 and appendix table 1-5). The highest detected concentration of a trace element was $3,680 \mu \mathrm{g} / \mathrm{L}$ for strontium in a sample from a bedrock well. The concentration of aluminum in one sample from a bedrock well, $200 \mu \mathrm{g} / \mathrm{L}$, exceeded the low end of the USEPA SDWS for aluminum of $50 \mu \mathrm{g} / \mathrm{L}$ and equaled the high end of $200 \mu \mathrm{g} / \mathrm{L}$. The concentration of manganese in one unfiltered sample $(145 \mu \mathrm{g} / \mathrm{L})$ and one filtered sample $(112 \mu \mathrm{g} / \mathrm{L})$ exceeded the USEPA SDWS of $50 \mu \mathrm{g} / \mathrm{L}$; the NYSDOH MCL of $300 \mu \mathrm{g} / \mathrm{L}$ was not exceeded in any sample. Drinking-water standards for antimony, arsenic, barium, beryllium, cadmium, chromium, copper, iron, lead, mercury, selenium, silver, thallium, zinc, and uranium were not exceeded; additionally, mercury and thallium were not detected in any sample (appendix table 1-1). 
Table 9. Drinking-water standards and summary statistics for concentrations of trace elements in groundwater samples from the Delaware River Basin, New York, 2010.

[All concentrations in micrograms per liter in unfiltered water except as noted. <, less than; E, estimated concentration; --, not applicable]

\begin{tabular}{|c|c|c|c|c|c|c|c|c|c|}
\hline \multirow[b]{3}{*}{ Constituent } & \multicolumn{9}{|c|}{ Summary statistics and concentrations } \\
\hline & \multirow{2}{*}{$\begin{array}{l}\text { Drinking- } \\
\text { water } \\
\text { standard }\end{array}$} & \multirow{2}{*}{$\begin{array}{l}\text { Number of } \\
\text { samples } \\
\text { exceeding } \\
\text { standard }\end{array}$} & \multirow{2}{*}{$\begin{array}{l}\text { Median } \\
\text { (all } \\
\text { samples) }\end{array}$} & \multicolumn{3}{|c|}{$\begin{array}{c}\text { Sand and gravel aquifers } \\
\text { (5 samples) }\end{array}$} & \multicolumn{3}{|c|}{$\begin{array}{c}\text { Bedrock aquifers } \\
\text { (5 samples) }\end{array}$} \\
\hline & & & & Minimum & Median & Maximum & Minimum & Median & Maximum \\
\hline Aluminum & $350-200$ & 1 & E7 & $<3$ & E4 & 13 & 3 & 25 & 200 \\
\hline Antimony & ${ }^{1,2} 6$ & 0 & $<.4$ & $<.2$ & $<.4$ & .2 & $<.2$ & $<.4$ & $<.4$ \\
\hline Arsenic & ${ }^{1,2} 10$ & 0 & .56 & .47 & .54 & 1.5 & .28 & .62 & 1.9 \\
\hline Barium & ${ }^{1,2} 2,000$ & 0 & 46.3 & 42.9 & 51.8 & 138 & 23.1 & 31.6 & 98.1 \\
\hline Beryllium & ${ }^{1,2} 4$ & 0 & $<.04$ & $<.02$ & $<.04$ & .03 & $<.02$ & $<.04$ & E.03 \\
\hline Boron, filtered & -- & -- & 17 & 11 & 18 & 33 & 3.6 & 16 & 40 \\
\hline Cadmium & ${ }^{1,2} 5$ & 0 & $<.05$ & $<.04$ & $<.05$ & .06 & $<.04$ & $<.04$ & $<.05$ \\
\hline Chromium & ${ }^{1,2} 100$ & 0 & $<.42$ & $<.21$ & $<.42$ & .32 & $<.21$ & $<.42$ & .58 \\
\hline Cobalt & -- & -- & .02 & $<.04$ & .02 & .04 & $<.02$ & .06 & .14 \\
\hline Copper & ${ }^{3} 1,000$ & 0 & 7.3 & 1.2 & 4.5 & 25.5 & 1.2 & 12.7 & 36.8 \\
\hline Iron, filtered & ${ }^{2,3} 300$ & 0 & $\mathrm{E} 4$ & $<3$ & 6 & 19 & $<6$ & E3 & 5 \\
\hline Iron & ${ }^{2,3} 300$ & 0 & 28 & E9 & 24 & 118 & 10 & 33 & 271 \\
\hline Lead & ${ }^{4} 15$ & 0 & .49 & .05 & .45 & 1.80 & .25 & .57 & 1.23 \\
\hline Lithium & -- & -- & 2.6 & E.2 & 2.6 & 11.7 & 1.0 & 8.7 & 14 \\
\hline Manganese, filtered & $\begin{array}{l}{ }^{2} 300 \\
{ }^{3} 50\end{array}$ & $\begin{array}{l}0 \\
1\end{array}$ & 3.8 & 1.2 & 11.3 & 112 & $<.2$ & 2.1 & 5.3 \\
\hline Manganese & $\begin{array}{l}{ }^{2} 300 \\
3_{50}\end{array}$ & $\begin{array}{l}0 \\
1\end{array}$ & 7.2 & 1.6 & 12.2 & 145 & 3.4 & 5 & 11.5 \\
\hline Mercury & ${ }^{1,2} 2$ & 0 & $<.010$ & $<.005$ & $<.005$ & $<.010$ & $<.005$ & $<.010$ & $<.010$ \\
\hline Molybdenum & -- & -- & $<.1$ & $<.1$ & $<.1$ & .2 & $<.1$ & .1 & 2.0 \\
\hline Nickel & -- & -- & .27 & $<.12$ & .20 & 3.7 & E.23 & .38 & .70 \\
\hline Selenium & ${ }^{1,2} 50$ & 0 & .11 & $<.05$ & .15 & .26 & $<.05$ & .11 & .29 \\
\hline Silver & ${ }^{2,3} 100$ & 0 & $<.02$ & $<.01$ & $<.01$ & .03 & $<.01$ & E.01 & .06 \\
\hline Strontium & -- & -- & 124 & 48.5 & 81.1 & 306 & 20.9 & 246 & 3,680 \\
\hline Thallium & ${ }^{1,2} 2$ & 0 & $<.12$ & $<.06$ & $<.06$ & $<.12$ & $<.06$ & $<.12$ & $<.12$ \\
\hline Zinc & ${ }^{2,3} 5,000$ & 0 & 5.2 & $<2.4$ & 6.7 & 18.8 & 2.4 & 2.9 & 79.0 \\
\hline Uranium & ${ }^{1,2} 30$ & 0 & .137 & E.014 & .085 & .501 & E.027 & .311 & .900 \\
\hline
\end{tabular}

${ }^{1}$ U.S. Environmental Protection Agency Maximum Contaminant Level.

${ }^{2}$ New York State Department of Health Maximum Contaminant Level.

${ }^{3}$ U.S. Environmental Protection Agency Secondary Drinking Water Standard.

${ }^{4}$ U.S. Environmental Protection Agency Treatment Technique.

\section{Pesticides}

Four pesticides and pesticide degradates were detected in four samples (appendix table 1-6); all were broadleaf herbicides or their degradates. Pesticides were detected in three samples from sand and gravel wells and in one sample from a bedrock well. All pesticide concentrations were in hundredths or thousandths of micrograms per liter; the constituent detected with the highest concentration (maximum $0.059 \mu \mathrm{g} / \mathrm{L}$ ) was atrazine. The most frequently detected pesticides were the herbicide degradate CIAT (2chloro-4-isopropylamino-6-amino-s-triazine, detected in four samples with an estimated maximum concentration of $0.077 \mu \mathrm{g} / \mathrm{L}$ ) and the herbicide atrazine (detected in three samples with a maximum concentration of $0.059 \mu \mathrm{g} / \mathrm{L}$ ). Simazine (an herbicide) was detected in two samples with a maximum 
concentration of $0.003 \mu \mathrm{g} / \mathrm{L}$, and prometon (an herbicide) was detected in one sample. One sample from a sand and gravel well had detections of four pesticides. Another sample had detections of three pesticides, and a third had detections of two pesticides. The bedrock well sample in which a pesticide was detected had a single pesticide detection. No pesticide concentrations exceeded established drinking-water standards; pesticide degradates currently are not regulated.

\section{Volatile Organic Compounds}

Five VOCs were detected in samples from two wells (appendix table 1-7); one sample from a production well finished in sand and gravel had detections of five VOCs, and one sample from a bedrock well had a detection of one VOC. The VOCs detected include four trihalomethanes (THMs) and tetrachloromethane. THMs are byproducts that form when chlorine or bromine are used as disinfectants; they are also used as solvents. Trichloromethane (chloroform) was detected in two samples with a maximum concentration of $0.3 \mu \mathrm{g} / \mathrm{L}$; the remaining THMs, including bromodichloromethane, tribromomethane, and dibromochloromethane, were detected in only one sample from a sand and gravel well. The maximum VOC concentration detected was $1.2 \mu \mathrm{g} / \mathrm{L}$ of dibromochloromethane. The concentration of total THMs did not exceed the NYSDOH and USEPA MCLs of $80 \mu \mathrm{g} / \mathrm{L}$.

Tetrachloromethane, a solvent, was detected in one sample from a sand and gravel well with a concentration of $0.8 \mu \mathrm{g} / \mathrm{L}$, which did not exceed the NYSDOH and USEPA MCLs of $5 \mu \mathrm{g} / \mathrm{L}$.

\section{Radionuclides}

Gross alpha activity ranged from non-detectable levels to $1.7 \mathrm{pCi} / \mathrm{L}$; the median activity was 0.7 pCi/L (table 10 and appendix table 1-8). The gross alpha activity did not exceed the NYSDOH and USEPA MCLs for gross alpha of $15 \mathrm{pCi} / \mathrm{L}$ in any sample. Gross beta activities ranged from nondetectable levels to $2.5 \mathrm{pCi} / \mathrm{L}$. The USEPA and NYSDOH MCLs for gross beta are expressed as a dose of 4 millirem per year. Radon-222 activities in the water samples ranged from 410 to 1,670 pCi/L; the median was $870 \mathrm{pCi} / \mathrm{L}$. The highest radon activities (more than 1,000 pCi/L) were in samples from bedrock wells. Radon is currently not regulated in drinking water; however, the USEPA has proposed a two-part standard for radon in drinking water: (1) a 300 pCi/L MCL for areas that do not implement an indoor-air radon mitigation program, and (2) an alternative MCL (AMCL) of 4,000 pCi/L for areas that do (U.S. Environmental Protection Agency, 1999). Activities in all of the samples exceeded the proposed MCL, but none exceeded the proposed AMCL.

Table 10. Drinking-water standards and summary statistics for concentrations of radionuclides in groundwater samples from the Delaware River Basin, New York, 2010.

[All activities in picocuries per liter in unfiltered water except as noted. mrem/yr, millirem per year; --, not applicable; <, less than]

\begin{tabular}{|c|c|c|c|c|c|c|c|c|c|}
\hline \multirow{2}{*}{ Constituent } & \multicolumn{9}{|c|}{ Summary statistics and activities } \\
\hline & $\begin{array}{l}\text { Drinking- } \\
\text { water } \\
\text { standard }\end{array}$ & $\begin{array}{l}\text { Number of } \\
\text { samples } \\
\text { exceeding } \\
\text { standard }\end{array}$ & $\begin{array}{c}\text { Median } \\
\text { (all } \\
\text { samples) }\end{array}$ & \multicolumn{3}{|c|}{$\begin{array}{l}\text { Sand and gravel aquifers } \\
\text { (5 samples) }\end{array}$} & \multicolumn{3}{|c|}{$\begin{array}{c}\text { Bedrock aquifers } \\
\text { (5 samples) }\end{array}$} \\
\hline Gross alpha radioactivity & 1,215 & 0 & 0.7 & $<0.67$ & $<0.96$ & 1.2 & 0.3 & 0.9 & 1.7 \\
\hline Gross beta radioactivity & $\begin{array}{r}{ }^{1,2} 4 \\
\text { mrem/yr }\end{array}$ & -- & $<.14$ & $<1.1$ & 2.0 & 2.5 & $<.86$ & $<1.3$ & 1.1 \\
\hline
\end{tabular}

\footnotetext{
${ }^{1}$ U.S. Environmental Protection Agency Maximum Contaminant Level.

${ }^{2}$ New York State Department of Health Maximum Contaminant Level.

${ }^{3}$ U.S. Environmental Protection Agency Proposed Maximum Contaminant Level.

${ }^{4}$ U.S. Environmental Protection Agency Proposed Alternative Maximum Contaminant Level.
} 


\section{Bacteria}

Coliform bacteria were detected in five samples (appendix table 1-9) with a maximum of 70 colony-forming units (CFUs) per $100 \mathrm{~mL}$; one of the positive results was in a presence/absence analysis and the remaining four were in most-probable-number defined-substrate analysis. Two samples with total coliform detections were from sand and gravel wells, and three were from bedrock wells. The NYSDOH and USEPA MCLs for total coliform bacteria are exceeded when 5 percent of samples of finished water collected in 1 month test positive for total coliform (if 40 or more samples are collected per month) or when two samples test positive for total coliform (if fewer than 40 samples are collected per month). Fecal coliform and Escherichia coli (E. coli) were not detected in any sample. The heterotrophic plate count ranged from $<1 \mathrm{CFU}$ per $\mathrm{mL}$ to $7,000 \mathrm{CFU}$ per $\mathrm{mL}$. The USEPA MCL for the heterotrophic plate count is $500 \mathrm{CFU} / \mathrm{mL}$; this limit was exceeded in one sample from a sand and gravel well.

Well sampled in 2005 and 2010

One of the wells sampled in 2010 (well SV1689) was sampled previously in 2005 as part of this study. Of the 147 constituents and physiochemical properties that samples were analyzed for in 2010, 140 were common to 2005 and 2010 analyses (appendix tables 1-10 through 1-13).

\section{Groundwater Quality in the St. Lawrence River Basin, New York}

The results of analyses of the 20 groundwater samples collected in the St. Lawrence study area during August through October 2010 are presented in tables 2-1 through 2-9 in appendix 2. Of the 147 constituents and physiochemical properties analyzed, 77 were not detected at levels greater than the LRLs in samples from the St. Lawrence study area (appendix table 1-1). Results for the remaining 70 constituents and properties that were detected in the St. Lawrence study area are presented in appendix 2, tables 2-2 through 2-9.

\section{Physiochemical Properties}

The color of samples ranged from $<1$ to 35 Pt-Co units; the median sample color was $<1 \mathrm{Pt}-\mathrm{Co}$ units (table 11 and appendix table 2-2). The color of one sample from a bedrock well, 35 Pt-Co units, exceeded the NYSDOH MCL and USEPA SDWS of 15 Pt-Co units. Dissolved oxygen concentration ranged from $<0.05$ to $9.7 \mathrm{mg} / \mathrm{L}$. Sample $\mathrm{pH}$ was typically near neutral or slightly basic (median 7.6 in all wells) and ranged from 6.5 to 8.5. All pH samples met the USEPA SDWS range for pH of 6.5 to 8.5. Specific conductance ranged from 75 to $1,280 \mu \mathrm{S} / \mathrm{cm}$ at $25^{\circ} \mathrm{C}$; the median conductance was $328 \mu \mathrm{S} / \mathrm{cm}$ at $25^{\circ} \mathrm{C}$. Water temperature ranged from 7.3 to $13.8^{\circ} \mathrm{C}$; the median temperature was $10.0^{\circ} \mathrm{C}$. Methane was detected in nine samples with a maximum concentration of $1.49 \mathrm{mg} / \mathrm{L}$. 
Table 11. Drinking-water standards and summary statistics for physiochemical properties of groundwater samples from the St. Lawrence River Basin, New York, 2010.

[All concentrations in unfiltered water except as noted. Pt-Co units, platinum-cobalt units; mg/L, milligrams per liter; $\mu \mathrm{S} / \mathrm{cm}$, microsiemens per centimeter at 25 degrees Celsius; ${ }^{\circ} \mathrm{C}$, degrees Celsius; --, not applicable; $<$, less than]

\begin{tabular}{|c|c|c|c|c|c|c|c|c|c|}
\hline \multirow{2}{*}{ Constituent } & \multicolumn{9}{|c|}{ Summary statistics and concentrations } \\
\hline & $\begin{array}{l}\text { Drinking- } \\
\text { water } \\
\text { standard }\end{array}$ & $\begin{array}{l}\text { Number of } \\
\text { samples } \\
\text { exceeding } \\
\text { standard }\end{array}$ & $\begin{array}{c}\text { Median (all } \\
\text { samples) }\end{array}$ & \multicolumn{3}{|c|}{$\begin{array}{c}\text { Sand and gravel aquifers } \\
\text { (5 samples) }\end{array}$} & \multicolumn{3}{|c|}{$\begin{array}{c}\text { Bedrock aquifers } \\
\text { (15 samples) }\end{array}$} \\
\hline Color, filtered, Pt-Co units & ${ }^{1} 15$ & 1 & $<1$ & $<1$ & $<1$ & 2 & $<1$ & $<1$ & 35 \\
\hline Carbon dioxide, mg/L & -- & -- & 7.0 & 2.7 & 9.8 & 30.4 & .5 & 7.2 & 49.2 \\
\hline $\mathrm{pH}$ & ${ }^{1} 6.5-8.5$ & 0 & 7.6 & 6.5 & 7.2 & 8.2 & 6.7 & 7.6 & 8.5 \\
\hline Specific conductance, $\mu \mathrm{S} / \mathrm{cm}$ & -- & -- & 328 & 96 & 208 & 1,280 & 75 & 363 & 669 \\
\hline Temperature, ${ }^{\circ} \mathrm{C}$ & -- & -- & 10.0 & 7.3 & 10.0 & 11.0 & 8.6 & 10.1 & 13.8 \\
\hline Argon, mg/L & -- & -- & .7851 & .7173 & .7389 & .7738 & .7183 & .8370 & .9192 \\
\hline Nitrogen gas, mg/L & -- & -- & 22.32 & 18.93 & 20.02 & 23.84 & 19.33 & 24.76 & 28.24 \\
\hline
\end{tabular}

${ }^{1}$ U.S. Environmental Protection Agency Secondary Drinking Water Standard.

\section{Major lons}

The anions detected in the highest concentrations were bicarbonate (median concentration 209 mg/L, maximum concentration 406 mg/L) and sulfate (median concentration $16.6 \mathrm{mg} / \mathrm{L}$, maximum concentration $78.5 \mathrm{mg} / \mathrm{L}$ ) (table 12 and appendix table 2-3). The cation detected in the highest concentration was calcium (median concentration $34.6 \mathrm{mg} / \mathrm{L}$, maximum concentration $108 \mathrm{mg} / \mathrm{L}$ ). The median concentrations of all major ions except silica were greater in samples from bedrock wells than in samples from sand and gravel wells, especially sodium (median $3.53 \mathrm{mg} / \mathrm{L}$ in sand and gravel wells and $12.54 \mathrm{mg} / \mathrm{L}$ in bedrock wells) and sulfate $(9.56 \mathrm{mg} / \mathrm{L}$ in sand and gravel wells and $23.0 \mathrm{mg} / \mathrm{L}$ in bedrock wells). The concentration of sodium in one sample from a sand and gravel well, $105 \mathrm{mg} / \mathrm{L}$, exceeded the USEPA Drinking Water Advisory Taste Threshold of $60 \mathrm{mg} / \mathrm{L}$. Water samples from the St. Lawrence study area were generally hard (121 to $180 \mathrm{mg} / \mathrm{L}$ as $\left.\mathrm{CaCO}_{3} ; \mathrm{Hem}, 1985\right)$, with a median hardness of 145 $\mathrm{mg} / \mathrm{L}$ as $\mathrm{CaCO}_{3}$. Five samples were soft (0 to $60 \mathrm{mg} / \mathrm{L}$ as $\mathrm{CaCO}_{3}$ ), four samples were moderately hard (61 to $120 \mathrm{mg} / \mathrm{L}$ as $\mathrm{CaCO}_{3}$ ), five samples were hard $\left(121\right.$ to $180 \mathrm{mg} / \mathrm{L}$ as $\left.\mathrm{CaCO}_{3}\right)$, and six samples were very hard (greater than $180 \mathrm{mg} / \mathrm{L}$ as $\mathrm{CaCO}_{3}$ ). Alkalinity ranged from 31 to $333 \mathrm{mg} / \mathrm{L}$ as $\mathrm{CaCO}_{3}$; the median was $140 \mathrm{mg} / \mathrm{L}$ as $\mathrm{CaCO}_{3}$. Dissolved solids ranged from 55 to $756 \mathrm{mg} / \mathrm{L}$ with a median of $196 \mathrm{mg} / \mathrm{L}$; the dissolved solids in one sample from a sand and gravel well, $756 \mathrm{mg} / \mathrm{L}$, exceeded the USEPA SDWS of $500 \mathrm{mg} / \mathrm{L}$. The concentrations of chloride, fluoride, and sulfate did not exceed established MCLs in any sample (table 12). 
Table 12. Drinking-water standards and summary statistics for concentrations of major ions in groundwater samples from the St. Lawrence River Basin, New York, 2010.

[All concentrations are in milligrams per liter in filtered water; --, not applicable; E, estimated concentration; ${ }^{\circ} \mathrm{C}$, degrees Celsius]

\begin{tabular}{|c|c|c|c|c|c|c|c|c|c|c|}
\hline & \multirow[b]{3}{*}{ Constituent } & \multicolumn{9}{|c|}{ Summary statistics and concentrations } \\
\hline & & \multirow{2}{*}{$\begin{array}{l}\text { Drinking- } \\
\text { water } \\
\text { standard }\end{array}$} & \multirow{2}{*}{$\begin{array}{l}\text { Number of } \\
\text { samples } \\
\text { exceeding } \\
\text { standard }\end{array}$} & \multirow{2}{*}{$\begin{array}{c}\text { Median (all } \\
\text { samples) }\end{array}$} & \multicolumn{3}{|c|}{$\begin{array}{c}\text { Sand and gravel aquifers } \\
\text { (5 samples) }\end{array}$} & \multicolumn{3}{|c|}{$\begin{array}{c}\text { Bedrock aquifers } \\
\text { (15 samples) }\end{array}$} \\
\hline & & & & & Minimum & Median & Maximum & Minimum & Median & Maximum \\
\hline \multirow{4}{*}{ 을 } & Calcium & -- & -- & 34.6 & 9.03 & 23.2 & 108 & 8.37 & 45.7 & 75.2 \\
\hline & Magnesium & -- & -- & 11.2 & 3.21 & 7.77 & 36.2 & 1.69 & 12.8 & 37.9 \\
\hline & Potassium & -- & -- & 1.42 & .69 & .86 & 4.08 & .43 & 1.45 & 13.8 \\
\hline & Sodium & ${ }^{4} 60$ & 1 & 8.44 & 2.76 & 3.53 & 105 & 2.21 & 12.4 & 32.2 \\
\hline \multirow{5}{*}{$\stackrel{\frac{0}{c}}{\frac{0}{E}}$} & Bicarbonate & -- & -- & 209 & 39 & 109 & 359 & 38 & 174 & 406 \\
\hline & Chloride & ${ }^{2,3} 250$ & 0 & 6.62 & 3.72 & 6.24 & 206 & .36 & 7.01 & 58.4 \\
\hline & Fluoride & $\begin{array}{l}{ }^{1} 4.0 \\
{ }^{2} 2.2 \\
{ }_{3}\end{array}$ & 0 & .28 & E.06 & .08 & .57 & .06 & .28 & .95 \\
\hline & Silica & -- & -- & 11.6 & 9.62 & 12.3 & 14.9 & 6.26 & 11.3 & 18.9 \\
\hline & Sulfate & ${ }^{2,3} 250$ & 0 & 16.6 & 7.48 & 9.56 & 78.5 & 2.89 & 23.0 & 49.5 \\
\hline \multicolumn{2}{|c|}{ Hardness as $\mathrm{CaCO}_{3}$} & -- & -- & 145 & 35.8 & 91.8 & 419 & 29 & 165 & 344 \\
\hline \multicolumn{2}{|c|}{ Alkalinity as $\mathrm{CaCO}_{3}$} & -- & -- & 140 & 32 & 89 & 294 & 31 & 143 & 333 \\
\hline \multicolumn{2}{|c|}{$\begin{array}{l}\text { Dissolved solids, dried } \\
\text { at } 180^{\circ} \mathrm{C}\end{array}$} & $3_{500}$ & 1 & 196 & 69 & 120 & 756 & 55 & 218 & 384 \\
\hline
\end{tabular}

${ }^{1}$ U.S. Environmental Protection Agency Maximum Contaminant.

${ }^{2}$ New York State Department of Health Maximum Contaminant Level.

${ }^{3}$ U.S. Environmental Protection Agency Secondary Drinking Water Standard.

${ }^{4}$ Level U.S. Environmental Protection Agency Drinking Water Advisory Taste Threshold.

\section{Nutrients and Total Organic Carbon}

The dominant nutrient detected in the St. Lawrence study area was nitrate (table 13 and appendix table 2-4). Concentrations of ammonia ranged from $<0.010$ to $0.350 \mathrm{mg} / \mathrm{L}$ as $\mathrm{N}$. Concentrations of nitrite plus nitrate ranged from $<0.02$ to $3.91 \mathrm{mg} / \mathrm{L}$ as $\mathrm{N}$; the median concentration was $0.09 \mathrm{mg} / \mathrm{L}$ as $\mathrm{N}$. The concentration of nitrate plus nitrite did not exceed the USEPA and NYSDOH MCL of $10 \mathrm{mg} / \mathrm{L}$ as N in any sample. Nitrite was detected in five samples with a maximum concentration of $0.011 \mathrm{mg} / \mathrm{L}$ as $\mathrm{N}$; the concentration of nitrite did not exceed the MCL ( $1 \mathrm{mg} / \mathrm{L}$ as $\mathrm{N})$ in any sample. Orthophosphate concentrations ranged from an estimated concentration of 0.006 to $0.089 \mathrm{mg} / \mathrm{L}$ as P. Total organic carbon was detected in all but 2 of the 20 samples; the maximum concentration was $2.2 \mathrm{mg} / \mathrm{L}$. 
Table 13. Drinking-water standards and summary statistics for concentrations of nutrients in groundwater samples from the St. Lawrence River Basin, New York, 2010.

[All concentrations in milligrams per liter in filtered water except as noted. N, nitrogen; P, phosphorus; --, not applicable; <, less than; E, estimated]

\begin{tabular}{|c|c|c|c|c|c|c|c|c|c|}
\hline \multirow{2}{*}{ Constituent } & \multicolumn{9}{|c|}{ Summary statistics and concentrations } \\
\hline & $\begin{array}{l}\text { Drinking- } \\
\text { water } \\
\text { standard }\end{array}$ & $\begin{array}{l}\text { Number of } \\
\text { samples } \\
\text { exceeding } \\
\text { standard }\end{array}$ & $\begin{array}{c}\text { Median (all } \\
\text { samples) }\end{array}$ & \multicolumn{3}{|c|}{$\begin{array}{l}\text { Sand and gravel aquifers } \\
\text { (5 samples) }\end{array}$} & \multicolumn{3}{|c|}{$\begin{array}{c}\text { Bedrock aquifers } \\
\text { (15 samples) }\end{array}$} \\
\hline $\begin{array}{l}\text { Ammonia plus organic } \mathrm{N} \text {, } \\
\text { as } \mathrm{N}\end{array}$ & -- & -- & E0.06 & $<0.05$ & $<0.10$ & E0.06 & $<0.05$ & E0.10 & 0.63 \\
\hline Nitrite $\left(\mathrm{NO}_{2}\right)$, as $\mathrm{N}$ & ${ }^{1,2} 1$ & 0 & $<.002$ & $<.001$ & $<.002$ & E.001 & $<.001$ & $<.002$ & .011 \\
\hline Orthophosphate $\left(\mathrm{PO}_{4}\right)$, as $\mathrm{P}$ & -- & -- & .012 & E.008 & .009 & .015 & E.006 & .015 & .089 \\
\hline $\begin{array}{l}\text { Total organic carbon } \\
\text { (TOC), unfiltered }\end{array}$ & -- & -- & .6 & $<.3$ & E.4 & .7 & $<.6$ & .7 & 2.2 \\
\hline
\end{tabular}

${ }^{1}$ U.S. Environmental Protection Agency Maximum Contaminant Level.

${ }^{2}$ New York State Department of Health Maximum Contaminant Level.

\section{Trace Elements}

The trace elements present in the highest median concentrations in the samples were strontium (median $210 \mu \mathrm{g} / \mathrm{L}$ ), iron (median $116 \mu \mathrm{g} / \mathrm{L}$ in unfiltered water; $23 \mu \mathrm{g} / \mathrm{L}$ in filtered water), barium (median $47.0 \mu \mathrm{g} / \mathrm{L}$ ), and boron (median $20 \mu \mathrm{g} / \mathrm{L}$ ) (table 14 and appendix table 2-5). The highest detected concentration of a trace element, 6,360 $\mu \mathrm{g} / \mathrm{L}$, was of strontium in a sample from a sand and gravel well. The concentration of aluminum in one sample, $1,310 \mu \mathrm{g} / \mathrm{L}$, exceeded the USEPA SDWS for aluminum of $200 \mu \mathrm{g} / \mathrm{L}$. The concentrations of iron in seven unfiltered samples and three filtered samples exceeded the NYSDOH and USEPA MCLs of $300 \mu \mathrm{g} / \mathrm{L}$. The concentration of manganese in five unfiltered samples and four filtered samples exceeded the USEPA SDWS of $50 \mu \mathrm{g} / \mathrm{L}$; the concentration of manganese in one unfiltered sample exceeded the NYSDOH MCL of $300 \mu \mathrm{g} / \mathrm{L}$. Drinking-water standards for antimony, arsenic, barium, beryllium, cadmium, chromium, copper, lead, mercury, selenium, silver, thallium, zinc, and uranium were not exceeded; additionally, thallium was not detected in any sample (appendix table 21). 
Table 14. Drinking-water standards and summary statistics for concentrations of trace elements in groundwater samples from the St. Lawrence River Basin, New York, 2010.

[All concentrations in micrograms per liter in unfiltered water except as noted. <, less than; E, estimated concentration; --, not applicable]

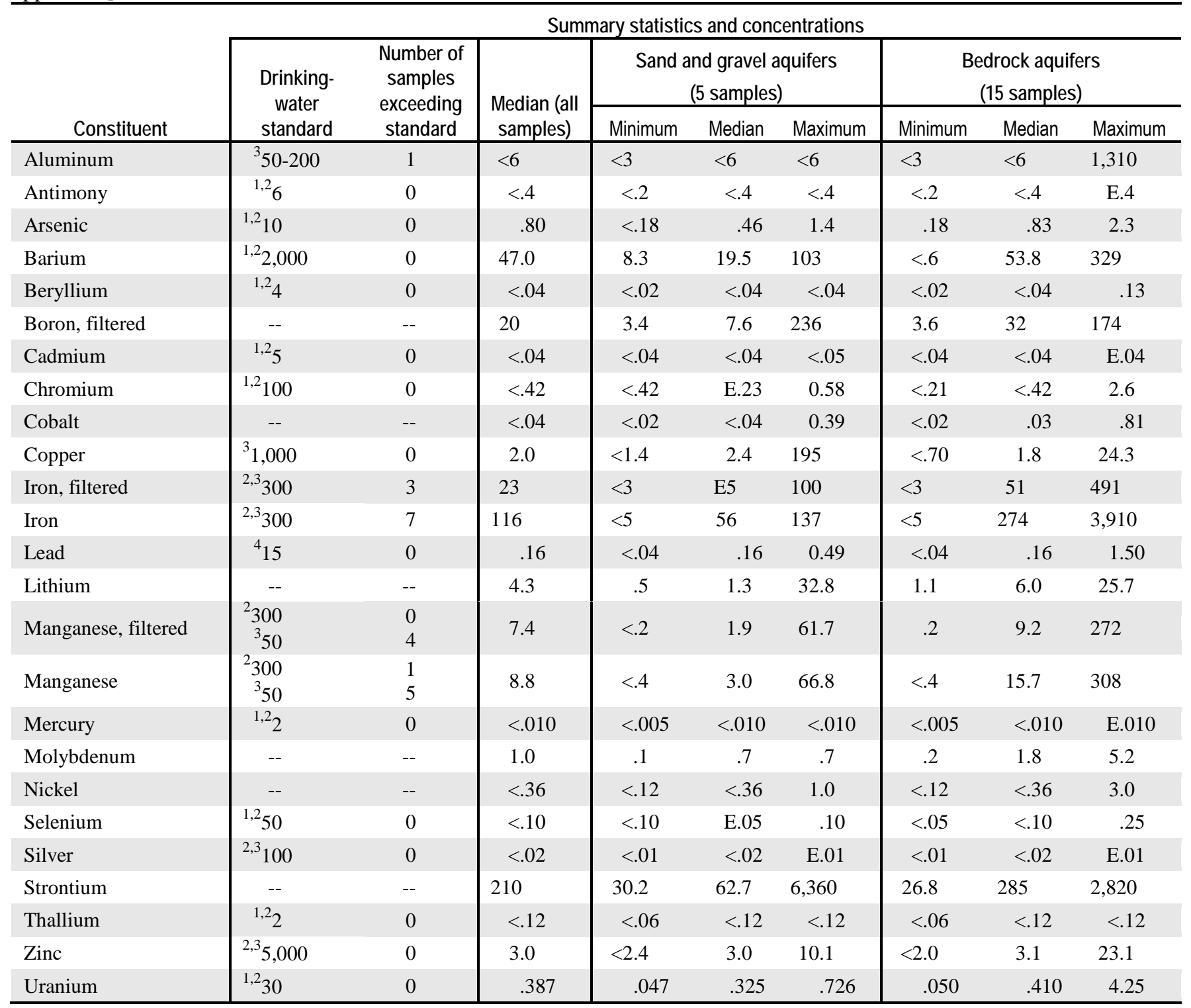

${ }^{1}$ U.S. Environmental Protection Agency Maximum Contaminant Level.

${ }^{2}$ New York State Department of Health Maximum Contaminant Level.

${ }^{3}$ U.S. Environmental Protection Agency Secondary Drinking Water Standard.

${ }^{4}$ U.S. Environmental Protection Agency Treatment Technique.

\section{Pesticides}

Seven pesticides and pesticide degradates were detected in 11 samples (appendix table 2-6). Six of the pesticides detected were herbicides or their degradates, and one was an insecticide. Pesticides were detected in three samples from sand and gravel wells and in eight samples from bedrock wells. Most pesticide concentrations were in hundredths or thousandths of micrograms per liter; the constituent detected with the highest concentration (estimated $0.11 \mu \mathrm{g} / \mathrm{L}$ ) was disulfoton.

The most frequently detected pesticides were the insecticide disulfoton (detected in five samples from bedrock wells) and the herbicide degradate CIAT (2-chloro-4-isopropylamino-6-amino-s-triazine, 
detected in four samples with an estimated maximum concentration of $0.031 \mu \mathrm{g} / \mathrm{L}$ ). The remaining five pesticides (atrazine, benfluralin, metolachlor, simazine, and terbacil), all herbicides, were detected in one sample each. Three samples had detections of two pesticides, and eight samples had detections of one pesticide. No pesticide concentrations exceeded established drinking-water standards; pesticide degradates currently are not regulated.

\section{Volatile Organic Compounds}

Three VOCs were detected in samples from two bedrock wells (appendix table 2-7). The VOCs detected include tetrachloroethene, toluene, and trichloromethane. One well (H80) had detections of two VOCs (tetrachloroethene and toluene), and one well (F1051) had one VOC detection (trichloromethane). Each VOC was detected in only one sample. Tetrachloroethene, a solvent, was detected at a concentration of $0.1 \mu \mathrm{g} / \mathrm{L}$, which did not exceed the NYSDOH and USEPA MCLs of $5 \mu \mathrm{g} / \mathrm{L}$. Toluene was detected at a concentration of $0.1 \mu \mathrm{g} / \mathrm{L}$, which did not exceed the NYSDOH MCL of $5 \mu \mathrm{g} / \mathrm{L}$ or the USEPA MCL of $1,000 \mu \mathrm{g} / \mathrm{L}$. Trichloromethane (chloroform), a trihalomethane, was detected at a concentration of 0.2 $\mu \mathrm{g} / \mathrm{L}$, which did not exceed the NYSDOH and USEPA MCLs of $80 \mu \mathrm{g} / \mathrm{L}$.

\section{Radionuclides}

Gross alpha activity ranged from non-detectable levels to $16 \mathrm{pCi} / \mathrm{L}$; the median activity was $<1.8$ $\mathrm{pCi} / \mathrm{L}$ (table 15 and appendix table 2-8). The gross alpha activity exceeded the NYSDOH and USEPA MCLs for gross alpha of $15 \mathrm{pCi} / \mathrm{L}$ in one sample. Gross beta activities ranged from non-detectable levels to $16.1 \mathrm{pCi} / \mathrm{L}$. Radon-222 activities in the water samples ranged from 17 to $2,580 \mathrm{pCi} / \mathrm{L}$; the median was $520 \mathrm{pCi} / \mathrm{L}$. The highest radon activities (over $1,000 \mathrm{pCi} / \mathrm{L}$ ) were in samples from bedrock wells.

Activities in 14 of the samples exceeded the proposed MCL for radon, but none exceeded the proposed AMCL.

Table 15. Drinking-water standards and summary statistics for activities of radionuclides in groundwater samples from the St. Lawrence River Basin, New York, 2010.

[All activities in picocuries per liter in unfiltered water except as noted. mrem/yr, millirem per year; --, not applicable; <, less than]

\begin{tabular}{|c|c|c|c|c|c|c|c|c|c|}
\hline \multirow{2}{*}{ Constituent } & \multicolumn{9}{|c|}{ Summary statistics and activities } \\
\hline & $\begin{array}{l}\text { Drinking- } \\
\text { water } \\
\text { standard }\end{array}$ & $\begin{array}{l}\text { Number of } \\
\text { samples } \\
\text { exceeding } \\
\text { standard }\end{array}$ & $\begin{array}{l}\text { Median (all } \\
\text { samples) }\end{array}$ & \multicolumn{3}{|c|}{$\begin{array}{c}\text { Sand and gravel aquifers } \\
\text { (5 samples) }\end{array}$} & \multicolumn{3}{|c|}{$\begin{array}{c}\text { Bedrock aquifers } \\
\text { (15 samples) }\end{array}$} \\
\hline Gross alpha radioactivity & 1,215 & 1 & $<1.8$ & $<0.55$ & $<1.8$ & 1.2 & $<.39$ & $<1.8$ & 16 \\
\hline Gross beta radioactivity & $1,24 \mathrm{mrem} / \mathrm{yr}$ & -- & 1.8 & $<1$ & .9 & 4.1 & $<.85$ & 2.7 & 16.1 \\
\hline
\end{tabular}

${ }^{1}$ U.S. Environmental Protection Agency Maximum Contaminant Level.

${ }^{2}$ New York State Department of Health Maximum Contaminant Level.

${ }^{3}$ U.S. Environmental Protection Agency Proposed Maximum Contaminant Level.

${ }^{4}$ U.S. Environmental Protection Agency Proposed Alternative Maximum Contaminant Level

\section{Bacteria}

Coliform bacteria were detected in seven samples (appendix table 2-9) with a maximum of more than 200 CFU per $100 \mathrm{~mL}$. One sample with total coliform bacteria detections was from sand and gravel wells, and six were from bedrock wells. E. coli were present in two samples. The heterotrophic plate 
count ranged from $<1 \mathrm{CFU}$ per $\mathrm{mL}$ to $600 \mathrm{CFU} / \mathrm{mL}$. The USEPA MCL for the heterotrophic plate count is $500 \mathrm{CFU} / \mathrm{mL}$; this limit was exceeded in two samples from bedrock wells and possibly was exceeded in samples from three additional wells (in which the heterotrophic plate count was quantified as greater than a given number).

\section{Wells sampled in 2005 and 2010}

Four of the wells sampled in 2010 (wells F543, F573, ST378, and ST950) were sampled previously in 2005 as part of this study. Of the 147 constituents and physiochemical properties that samples were analyzed for in 2009, 140 were common to 2005 and 2010 analyses (appendix tables 2-10 through 2-13). The differences between 2005 and 2010 results for a single well were typically smaller than those between the results from different wells; there were no consistent overall trends in concentrations.

\section{Summary}

Groundwater samples were collected from August through November 2010 from 10 wells in the Delaware River Basin and 20 wells in the St. Lawrence River Basin in New York to characterize the groundwater quality. Sample collection and analysis followed standard USGS procedures and other documented procedures. Samples were analyzed for physical properties and concentrations of major ions, nutrients, trace elements, pesticides, volatile organic compounds (VOCs), radionuclides, and bacteria. Many of the 147 constituents were not detected in any of the samples.

The depths of sand and gravel wells sampled in the Delaware study area range from 38 to $100 \mathrm{ft}$ below land surface; the bedrock wells are 240 to $550 \mathrm{ft}$ deep and typically are completed in sandstone and shale bedrock. Five of the 10 wells sampled are production wells; 5 are domestic wells. The samples generally indicated good water quality, although properties and concentrations of some constituents- $\mathrm{pH}$, aluminum, manganese, radon-222, and bacteria - equaled or exceeded primary, secondary, or proposed drinking-water standards. The constituents most frequently detected in concentrations exceeding drinking-water standards were radon-222 (all 10 samples had concentrations greater than the USEPA proposed MCL of $300 \mathrm{pCi} / \mathrm{L}$ ), coliform bacteria (5 samples with detections), and $\mathrm{pH}$ (3 samples with $\mathrm{pH}$ lower than the USEPA SDWS). Sample $\mathrm{pH}$ was typically near neutral or slightly acidic. The water typically was soft, but hardness ranged from soft to hard. The ions detected in the highest median concentrations were bicarbonate, chloride, and calcium. The dominant nutrient was nitrate; concentrations of nitrate and nitrite did not exceed established drinking-water standards. Strontium was the trace element with the highest median concentrations. Radon-222 activities in all 10 samples exceeded a proposed MCL, but none exceeded the proposed AMCL. Four pesticides and pesticide degradates were detected in four samples. Three samples were from sand and gravel wells, and one was from a bedrock well; all were trace-level detections of broadleaf herbicides or their degradates. Five VOCs were detected in two samples, including four trihalomethanes (disinfection byproducts) and tetrachloromethane. Coliform bacteria were detected in five samples. Fecal coliform and E. coli bacteria were not detected in any sample.

The depths of sand and gravel wells sampled in the St. Lawrence study area range from 41 to 236 $\mathrm{ft}$ below land surface; the bedrock wells are 60 to $500 \mathrm{ft}$ deep and are completed in crystalline, carbonate, or sandstone bedrock. Ten of the 20 wells sampled are production or municipal wells, and 10 are domestic wells. The samples generally indicated good water quality, although properties and concentrations of some constituents - color, sodium, total dissolved solids, aluminum, iron, manganese, gross alpha radioactivity, radon-222, and bacteria-equaled or exceeded primary, secondary, or proposed drinking-water standards. The constituents most frequently detected in concentrations exceeding drinking-water standards are radon-222 (14 samples with concentrations greater than the USEPA proposed MCL of $300 \mathrm{pCi} / \mathrm{L}$ ), coliform bacteria (7 samples with detections), iron (7 unfiltered samples with concentrations greater than the USEPA SDWS and NYSDOH MCL of $300 \mu \mathrm{g} / \mathrm{L}$ ), and manganese (5 
unfiltered samples with concentrations greater than the USEPA SDWS of $50 \mu \mathrm{g} / \mathrm{L}$ ). Sample pH typically was near neutral or slightly basic. The water hardness ranged from soft to very hard; more samples were hard than were soft. The ions detected in the highest median concentrations were bicarbonate, sulfate, and calcium. The dominant nutrient was nitrate; concentrations of nitrate and nitrite did not exceed established drinking-water standards. Strontium was the trace element with the highest median concentrations. The highest radon-222 activities were in samples from bedrock wells (maximum 2,580 $\mathrm{pCi} / \mathrm{L}$ ). Seven pesticides and pesticide degradates were detected in 11 samples; most detections were of broadleaf herbicides or their degradates at trace levels. Pesticides were detected in three samples from sand and gravel wells and eight samples from bedrock wells. Three VOCs (tetrachloroethene, toluene, and trichloromethane) were detected in two samples from bedrock wells. Coliform bacteria were detected in seven samples, and E. coli bacteria were detected in two samples.

\section{References Cited}

Barksdale, H.C., 1970, A program for the investigation and management of ground water in the Delaware River Basin: Newark, N.J., Delaware River Basin Commission, 120 p.

Butch, G.K., Murray, P.M., Hebert, G.J., and Weigel, J.F., 2003, Water resources data, New York, water year 2002: U.S. Geological Survey Water-Data Report NY-02-1, p. 502-520.

Cadwell, D.H., 1991, Surficial geologic map of New York: New York State Museum Map and Chart Series no. 40, Lower Hudson sheet, scale 1:250,000.

Childress, C.J.O., Foreman, W.T., Connor, B.F., and Maloney, T.J., 1999, New reporting procedures based on long-term method detection levels and some considerations for interpretations of water-quality data provided by the U.S. Geological Survey National Water Quality Laboratory: U.S. Geological Survey Open-File Report 99-193, 19 p.

Eckhardt, D.A., Reddy, J.E., and Shaw, S.B., 2009, Groundwater quality in central New York, 2007: U.S. Geological Survey Open-File Report 2009-1257, 40 p., accessed August 15, 2011, at http://pubs.usgs.gov/of/2009/1257/.

Eckhardt, D.A., Reddy, J.E., and Tamulonis, K.L., 2007, Ground-water quality in the Genesee River Basin, New York, 2005-06: U.S. Geological Survey Open-File Report 2007-1093, 26 p., accessed August 15, 2011, at http://pubs.usgs.gov/of/2007/1093/.

Eckhardt, D.A., Reddy, J.E., and Tamulonis, K.L., 2008, Ground-water quality in western New York, 2006: U.S. Geological Survey Open-File Report 2008-1140, 36 p., accessed August 15, 2011, at http://pubs.usgs.gov/of/2008/1140/.

Fisher, D.W., Isachsen, Y.W., and Rickard, L.V., 1970, Geologic map of New York State: New York State Museum Map and Chart Series no. 15, Lower Hudson sheet, scale 1:250,000.

Government of Canada and U.S. Environmental Protection Agency, 1995, The Great Lakes-An Environmental Atlas and Resource Book: U.S. Environmental Protection Agency Report 905-B-95-001, $46 \mathrm{p}$.

Great Lakes Basin Commission, 1975, Great Lakes Basin Framework Study--Appendix 3, Geology and Ground Water: Ann Arbor, Mich., Great Lakes Basin Commission, 152 p.

Hem, J.D., 1985, Study and interpretation of the chemical characteristics of natural water (3d ed.): U.S. Geological Survey Water-Supply Paper 2254, 264 p.

Hetcher-Aguila, K.K., 2005, Ground-water quality in the Chemung River Basin, New York, 2003: U.S. Geological Survey Open-File Report 2004-1329, 19 p., accessed August 15, 2011, at http://ny.water.usgs.gov/pubs/of/of041329/.

Hetcher-Aguila, K.K., and Eckhardt, D.A., 2006, Ground-water quality in the upper Susquehanna River Basin, New York, 2004: U.S. Geological Survey Open-File Report 2006-1161, 21 p., accessed August 15, 2011, at http://pubs.usgs.gov/of/2006/1161/. 
Isachsen, Y.W., Landing, E., Lauber, J.M., Rickard, L.V., and Rogers, W.B., eds., 2000, Geology of New York-A simplified account (2d ed.): Albany, N.Y., New York State Museum/Geological Survey, 294 p.

New York State Department of Health, 2007, New York State Health Department public water systems regulations: Albany, N.Y. [variously paged], accessed March 25, 2009, at http://www.health.state.ny.us/environmental/water/drinking/part5/tables.htm.

Nystrom, E.A., 2006, Ground-water quality in the Lake Champlain Basin, New York, 2004: U.S. Geological Survey Open-File Report 2006-1088, 22 p., accessed August 15, 2011, at http://pubs.usgs.gov/of/2006/1088/.

Nystrom, E.A., 2007a, Ground-water quality in the St. Lawrence River Basin, New York, 2005-06: U.S. Geological Survey Open-File Report 2007-1066, 33 p., accessed August 15, 2011, at http://pubs.usgs.gov/of/2007/1066/.

Nystrom, E.A., 2007b, Ground-water quality in the Delaware River Basin, New York, 2001 \& 2005-06: U.S. Geological Survey Open-File Report 2007-1098, 36 p., accessed August 15, 2011, at http://pubs.usgs.gov/of/2007/1098/.

Nystrom, E.A., 2008, Ground-water quality in the Mohawk River Basin, New York, 2006: U.S. Geological Survey Open-File Report 2008-1086, 33 p., accessed August 15, 2011, at http://pubs.usgs.gov/of/2008/1086/.

Nystrom, E.A., 2009, Groundwater quality in the Upper Hudson River Basin, New York, 2007: U.S. Geological Survey Open-File Report 2009-1240, 37 p., accessed August 15, 2011, at http://pubs.usgs.gov/of/2009/1240/.

Nystrom, E.A., 2010, Groundwater quality in the Lower Hudson River Basin, New York, 2008: U.S. Geological Survey Open-File Report 2010-1197, 39 p., accessed August 15, 2011, at http://pubs.usgs.gov/of/2010/1197/.

Nystrom, E.A., 2011, Groundwater quality in the Lake Champlain Basin, New York, 2009: U.S. Geological Survey Open-File Report 2011-1180, 42 p., accessed August15, 2011, at http://pubs.usgs.gov/of/2011/1180/.

Risen, A.J., and Reddy, J.E., 2011a, Groundwater quality in the Chemung River Basin, 2008: U.S. Geological Survey Open-File Report 2011-1112, 25 p., accessed August 15, 2011, at http://pubs.usgs.gov/of/2011/1112/.

Risen, A.J., and Reddy, J.E., 2011b, Groundwater quality in the Eastern Lake Ontario Basin New York, 2008: U.S. Geological Survey Open-File Report 2011-1074, 32 p., accessed August 15, 2011, at http://pubs.usgs.gov/of/2011/1074/.

U.S. Environmental Protection Agency, 1997, Guidelines for preparation of the comprehensive state water quality assessments (305(b) Reports) and electronic updates: Washington, D.C., U.S. Environmental Protection Agency, Office of Water, EPA 841-B-97-002A and EPA 841-B-97-002B, PL95-217, 271 p.

U.S. Environmental Protection Agency, 1999, Proposed radon in drinking water rule: Washington, D.C., U.S. Environmental Protection Agency, Office of Water, EPA 815-F-99-006, 6 p.

U.S. Environmental Protection Agency, 2009, National primary drinking water standards and national secondary drinking water standards: Washington, D.C., U.S. Environmental Protection Agency, Office of Water, EPA 816-F-09-0004, 6 p., accessed March 25, 2009, at http://www.epa.gov/safewater/consumer/pdf/mcl.pdf.

U.S. Geological Survey, variously dated, National field manual for the collection of water-quality data: U.S. Geological Survey Techniques of Water-Resource Investigations, book 9, chaps. A1-A9 [variously paged].

Vogelmann, J.E., Howard, S.M., Yang, L., Larson, C.R., Wylie, B.K., and Van Driel, J.N., 2001, Completion of the 1990's National Land Cover Data Set for the conterminous United States: Photogrammetric Engineering and Remote Sensing, v. 67, p. 650-662. 


\section{Appendix 1: Results of Water-Sample Analyses in the Delaware River Basin}

The following tables summarize results of the chemical analyses of the 10 samples collected in the Delaware River Basin in New York from August through November 2010.

Table 1-1. Constituents that were not detected in groundwater samples collected in the Delaware River Basin, New York, 2010.

Table 1-2. Physiochemical properties of groundwater samples collected in the Delaware River Basin, New York, 2010.

Table 1-3. Concentrations of major ions in groundwater samples collected in the Delaware River Basin, New York, 2010.

Table 1-4. Concentrations of nutrients and organic carbon in groundwater samples collected in the Delaware

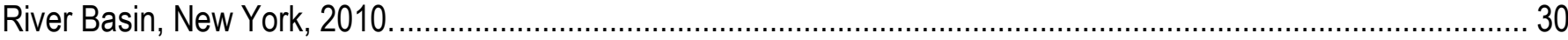
Table 1-5. Concentrations of trace elements in groundwater samples collected in the Delaware River Basin, New York, 2010.

Table 1-6. Concentrations of pesticides detected in groundwater samples collected in the Delaware River Basin, New York, 2010

Table 1-7. Concentrations of volatile organic compounds detected in groundwater samples collected in the Delaware River Basin, New York, 2010.

Table 1-8. Activities of radionuclides in groundwater samples from the Delaware River Basin, New York, 2010. 33

Table 1-9. Bacteria in groundwater samples collected in the Delaware River Basin, New York, 2010. 33

Table 1-10. Physiochemical properties and concentrations of major ions, nutrients, and bacteria in groundwater samples collected in the Delaware River Basin, New York, 2005 and 2010.

Table 1-11. Concentrations of trace elements and radionuclides in groundwater samples in the Delaware River Basin, New York, 2005 and 2010.

Table 1-12. Concentrations of pesticides in groundwater samples collected in the Delaware River Basin, New York, 2005 and 2010.

Table 1-13. Concentrations of volatile organic compounds in groundwater samples collected in the Delaware River 
Table 1-1. Constituents that were not detected in groundwater samples collected in the Delaware River Basin, New York, 2010.

[NWIS, National Water Information System; WY, water year, the 12-month period from October 1 through September 30 of the following year. The water year is designated by the calendar year in which it ends]

\begin{tabular}{|c|c|c|c|}
\hline \multirow{2}{*}{$\begin{array}{l}\text { U.S. Geological } \\
\text { Survey NWIS } \\
\text { parameter code }\end{array}$} & \multirow[b]{2}{*}{ Constituent } & \multicolumn{2}{|c|}{$\begin{array}{c}\text { Laboratory reporting } \\
\text { level }\end{array}$} \\
\hline & & WY10 & WY11 \\
\hline \multicolumn{4}{|c|}{ Trace Elements in unfiltered water, in micrograms per liter } \\
\hline 71900 & Mercury & 0.010 & 0.005 \\
\hline 01059 & Thallium & .12 & .06 \\
\hline \multicolumn{4}{|c|}{ Pesticides in filtered water, in micrograms per liter } \\
\hline 82660 & 2,6-Diethylaniline & .006 & .006 \\
\hline 49260 & Acetochlor & .010 & .010 \\
\hline 46342 & Alachlor & .008 & .008 \\
\hline 34253 & alpha-HCH & .004 & .004 \\
\hline 82686 & Azinphos-methyl & .120 & .120 \\
\hline 82673 & Benfluralin & .014 & .014 \\
\hline 04028 & Butylate & .004 & .004 \\
\hline 82680 & Carbaryl & .060 & .060 \\
\hline 82674 & Carbofuran & .060 & .060 \\
\hline 38933 & Chlorpyrifos & .010 & .004 \\
\hline 82687 & cis-Permethrin & .014 & .010 \\
\hline 04041 & Cyanazine & .022 & .022 \\
\hline 82682 & DCPA & .008 & .008 \\
\hline 62170 & Desulfinylfipronil & .012 & .012 \\
\hline 39572 & Diazinon & .005 & .006 \\
\hline 39381 & Dieldrin & .009 & .008 \\
\hline 82677 & Disulfoton & .04 & .04 \\
\hline 82668 & EPTC & .002 & .006 \\
\hline 82663 & Ethalfluralin & .006 & .006 \\
\hline 82672 & Ethoprop & .016 & .016 \\
\hline 62169 & Desulfinylfipronil amide & .029 & .029 \\
\hline 62167 & Fipronil sulfide & .013 & .012 \\
\hline 62168 & Fipronil sulfone & .024 & .024 \\
\hline 62166 & Fipronil & .018 & .018 \\
\hline 04095 & Fonofos & .004 & .005 \\
\hline 39341 & Lindane & .004 & .004 \\
\hline 82666 & Linuron & .060 & .060 \\
\hline 39532 & Malathion & .016 & .016 \\
\hline 82667 & Methyl parathion & .008 & .008 \\
\hline 39415 & Metolachlor & .014 & .014 \\
\hline 82630 & Metribuzin & .012 & .012 \\
\hline 82671 & Molinate & .003 & .004 \\
\hline 82684 & Napropamide & .008 & .008 \\
\hline 34653 & $p, p^{\prime}-\mathrm{DDE}$ & .002 & .002 \\
\hline 39542 & Parathion & .020 & .020 \\
\hline 82669 & Pebulate & .016 & .016 \\
\hline 82683 & Pendimethalin & .012 & .012 \\
\hline 82664 & Phorate & .020 & .020 \\
\hline
\end{tabular}


Table 1-1. Constituents that were not detected in groundwater samples collected in the Delaware River Basin, New York, 2010.-Continued

[NWIS, National Water Information System; WY, water year, the 12-month period from October 1 through September 30 of the following year. The water year is designated by the calendar year in which it ends]

\begin{tabular}{llcc}
\hline \multirow{2}{*}{$\begin{array}{c}\text { U.S. Geological } \\
\text { Survey NWIS } \\
\text { parameter code }\end{array}$} & \multicolumn{1}{c}{ Constituent } & \multicolumn{2}{c}{$\begin{array}{c}\text { Laboratory reporting } \\
\text { level }\end{array}$} \\
\cline { 3 - 4 } & & WY10 & WY11 \\
\hline Pesticides in filtered water, in micrograms per liter--continued & & \\
\hline 82676 & Propyzamide & .004 & .004 \\
04024 & Propachlor & .006 & .006 \\
82679 & Propanil & .010 & .010 \\
82685 & Propargite & .02 & .02 \\
82670 & Tebuthiuron & .03 & .03 \\
82665 & Terbacil & .024 & .024 \\
82675 & Terbufos & .02 & .02 \\
82681 & Thiobencarb & .016 & .016 \\
82678 & Triallate & .006 & .005 \\
82661 & Trifluralin & .018 & .018 \\
\hline
\end{tabular}

\begin{tabular}{|c|c|c|c|}
\hline 34506 & 1,1,1-Trichloroethane & .1 & .1 \\
\hline 77652 & 1,1,2-Trichloro-1,2,2-trifluoroethane & .1 & .1 \\
\hline 34496 & 1,1-Dichloroethane & .1 & .1 \\
\hline 34501 & 1,1-Dichloroethene & .1 & .1 \\
\hline 34536 & 1,2-Dichlorobenzene & .1 & .1 \\
\hline 32103 & 1,2-Dichloroethane & .2 & .2 \\
\hline 34541 & 1,2-Dichloropropane & .1 & .1 \\
\hline 34566 & 1,3-Dichlorobenzene & .1 & .1 \\
\hline 34571 & 1,4-Dichlorobenzene & .1 & .1 \\
\hline 34030 & Benzene & .1 & .1 \\
\hline 34301 & Chlorobenzene & .1 & .1 \\
\hline 77093 & cis-1,2-Dichloroethene & .1 & .1 \\
\hline 34668 & Dichlorodifluoromethane & .2 & .2 \\
\hline 34423 & Dichloromethane & .2 & .2 \\
\hline 81576 & Diethyl ether & .2 & .2 \\
\hline 81577 & Diisopropyl ether & .2 & .2 \\
\hline 34371 & Ethylbenzene & .1 & .1 \\
\hline 50005 & Methyl tert-pentyl ether & .2 & .2 \\
\hline 85795 & $m$-Xylene plus $p$-xylene & .2 & .2 \\
\hline 77135 & o-Xylene & .1 & .1 \\
\hline 77128 & Styrene & .1 & .1 \\
\hline 50004 & tert-Butyl ethyl ether & .1 & .1 \\
\hline 78032 & Methyl tert-butyl ether & .2 & .2 \\
\hline 34475 & Tetrachloroethene & .1 & .1 \\
\hline 34010 & Toluene & .1 & .1 \\
\hline 34546 & trans-1,2-Dichloroethene & .1 & .1 \\
\hline 39180 & Trichloroethene & .1 & .1 \\
\hline 34488 & Trichlorofluoromethane & .2 & .2 \\
\hline 39175 & Vinyl chloride & .2 & .2 \\
\hline
\end{tabular}


Table 1-2. Physiochemical properties of groundwater samples collected in the Delaware River Basin, New York, 2010.

[mg/L, milligrams per liter; $\mu \mathrm{S} / \mathrm{cm} @ 25^{\circ} \mathrm{C}$, microsiemens per centimeter at 25 degrees Celsius; (00080), U.S. Geological Survey National Water Information System parameter code; <, less than. Bold values exceed one or more drinking-water standards. Well locations are shown in figures 1 and 2]

\begin{tabular}{|c|c|c|c|c|c|}
\hline $\begin{array}{c}\text { Well } \\
\text { number }^{1}\end{array}$ & $\begin{array}{c}\text { Color, } \\
\text { platinum-cobalt } \\
\text { units } \\
(00080) \\
\end{array}$ & $\begin{array}{c}\text { Carbon } \\
\text { dioxide, } \\
\mathrm{mg} / \mathrm{L} \\
(00405)\end{array}$ & $\begin{array}{l}\text { Dissolved } \\
\text { oxygen, } \\
\text { mg/L } \\
(00300) \\
\end{array}$ & $\begin{array}{c}\mathrm{pH}, \\
\text { field, } \\
\text { standard units } \\
(00400) \\
\end{array}$ & $\begin{array}{c}\text { Specific } \\
\text { conductance, } \\
\text { field, } \\
\mu S / \mathrm{cm} @ 25^{\circ} \mathrm{C} \\
(00095)\end{array}$ \\
\hline \multicolumn{6}{|c|}{ Sand and gravel wells } \\
\hline BM1405 & $<1$ & 4.7 & 1.6 & 7.6 & 327 \\
\hline D523 & $<1$ & 31.0 & .5 & 6.4 & 278 \\
\hline SV534 & $<1$ & 76.5 & 6.1 & 5.6 & 176 \\
\hline SV555 & $<1$ & 37.2 & 1.1 & 6.5 & 232 \\
\hline SV884 & $<1$ & 16.6 & 7.2 & 6.8 & 355 \\
\hline \multicolumn{6}{|c|}{ Bedrock wells } \\
\hline D1191 & $<1$ & 23.2 & 5.0 & 6.8 & 200 \\
\hline SV551 & $<1$ & 2.4 & $<.3$ & 7.7 & 375 \\
\hline SV1689 & $<1$ & 10.1 & 7.2 & 6.9 & 99 \\
\hline SV2320 & $<1$ & 27.2 & 8.8 & 6.3 & 66 \\
\hline U2705 & $<1$ & 32.1 & 9.6 & 5.6 & 44 \\
\hline $\begin{array}{c}\text { Well } \\
\text { number}^{1}\end{array}$ & $\begin{array}{c}\text { Water } \\
\text { temperature, } \\
\text { field, } \\
\text { degrees Celsius } \\
(00010)\end{array}$ & $\begin{array}{c}\text { Argon, } \\
\text { unfiltered, } \\
\text { mg/L } \\
(82043)\end{array}$ & $\begin{array}{c}\text { Dissolved } \\
\text { nitrogen gas, } \\
\text { unfiltered, } \\
\text { mg/L } \\
(00597)\end{array}$ & $\begin{array}{l}\text { Hydrogen } \\
\text { sulfide odor } \\
\text { field, } \\
\text { (71875) }\end{array}$ & $\begin{array}{c}\text { Methane, } \\
\text { unfiltered, } \\
\text { mg/L } \\
(76994)\end{array}$ \\
\hline \multicolumn{6}{|c|}{ Sand and gravel wells } \\
\hline BM1405 & 10.9 & 0.7739 & 22.39 & Absent & E0.0002 \\
\hline D523 & 14.9 & .5759 & 16.05 & Absent & .0008 \\
\hline SV534 & 11.6 & .7115 & 18.99 & Absent & $<.0005$ \\
\hline SV555 & 9.3 & .7108 & 20.25 & Absent & $<.0005$ \\
\hline SV884 & 11.9 & .7245 & 19.92 & Absent & .0010 \\
\hline \multicolumn{6}{|c|}{ Bedrock wells } \\
\hline D1191 & 9.8 & .7242 & 19.98 & Absent & $<.0005$ \\
\hline SV551 & 12.6 & .8252 & 23.88 & Absent & .014 \\
\hline SV1689 & 9.1 & .7175 & 19.38 & Absent & $<.0005$ \\
\hline SV2320 & 9.7 & 6949 & 18.47 & Absent & $<.0005$ \\
\hline U2705 & 8.2 & .6763 & 17.37 & Absent & $<.0005$ \\
\hline
\end{tabular}

${ }^{1}$ BM, Broome County; D, Delaware County; SV, Sullivan County; U, Ulster County. 
Table 1-3. Concentrations of major ions in groundwater samples collected in the Delaware River Basin, New York, 2010.

[mg/L, milligrams per liter; $\mathrm{CaCO}_{3}$, calcium carbonate; (00900), U.S. Geological Survey National Water Information System parameter code; <, less than; E, estimated concentration; ${ }^{\circ}$ Celsius; degrees Celsius. Bold values exceed one or more drinkingwater standards. Well locations are shown in figures 1 and 2]

\begin{tabular}{|c|c|c|c|c|c|c|c|}
\hline $\begin{array}{c}\text { Well } \\
\text { number1 }\end{array}$ & $\begin{array}{l}\text { Hardness, } \\
\text { filtered, } \\
\text { mg/L as } \\
\mathrm{CaCO}_{3} \\
(00900)\end{array}$ & $\begin{array}{c}\text { Calcium, } \\
\text { filtered, } \\
\text { mg/L } \\
(00915)\end{array}$ & $\begin{array}{l}\text { Magnesium, } \\
\text { filtered, } \\
\mathrm{mg} / \mathrm{L} \\
(00925)\end{array}$ & $\begin{array}{l}\text { Potassium, } \\
\text { filtered, } \\
\text { mg/L } \\
(00935)\end{array}$ & $\begin{array}{c}\text { Sodium, } \\
\text { filtered, } \\
\text { mg/L } \\
(00930)\end{array}$ & $\begin{array}{c}\text { Acid } \\
\text { neutralizing } \\
\text { capacity, } \\
\text { unfiltered, } \\
\mathrm{mg}^{\prime} \mathrm{L} \text { as } \\
\mathrm{CaCO}_{3} \\
(90410)\end{array}$ & $\begin{array}{l}\text { Alkalinity, } \\
\text { filtered, } \\
\text { fixed endpoint, } \\
\text { laboratory, } \\
\text { mg/L as CaCO } \\
\text { (29801) }\end{array}$ \\
\hline \multicolumn{8}{|c|}{ Sand and gravel wells } \\
\hline BM1405 & 138 & 40.7 & 8.76 & 1.23 & 10.9 & 100 & 100 \\
\hline D523 & 51.4 & 15.2 & 3.23 & 1.94 & 29.6 & 43 & 43 \\
\hline SV534 & 30.4 & 9.62 & 1.54 & 1.58 & 19.3 & 19 & 19 \\
\hline SV555 & 87.1 & 27.9 & 4.26 & 1.03 & 13.6 & 64 & 65 \\
\hline SV884 & 69.4 & 18.8 & 5.42 & 2.79 & 43.2 & 75 & 75 \\
\hline \multicolumn{8}{|c|}{ Bedrock wells } \\
\hline D1191 & 61.4 & 20.0 & 2.78 & .70 & 15.7 & 70 & 70 \\
\hline SV551 & 163 & 44.6 & 12.5 & .89 & 11.3 & 94 & 94 \\
\hline SV1689 & 41.1 & 13.5 & 1.79 & .73 & 3.60 & 42 & 43 \\
\hline SV2320 & 29.0 & 9.04 & 1.55 & .52 & .76 & 26 & 26 \\
\hline U2705 & 14.5 & 3.90 & 1.15 & .36 & 1.75 & 10 & 9 \\
\hline
\end{tabular}

\begin{tabular}{|c|c|c|c|c|c|c|}
\hline $\begin{array}{c}\text { Well } \\
\text { number }^{1}\end{array}$ & $\begin{array}{l}\text { Bicarbonate, } \\
\text { filtered, } \\
\text { fixed endpoint, } \\
\text { laboratory, } \\
\text { mg/L } \\
(29805)\end{array}$ & $\begin{array}{c}\text { Chloride, } \\
\text { filtered, } \\
\text { mg/L } \\
(00940)\end{array}$ & $\begin{array}{c}\text { Fluoride, } \\
\text { filtered, } \\
\text { mg/L } \\
(00950)\end{array}$ & $\begin{array}{c}\text { Silica, } \\
\text { filtered, } \\
\text { mg/L } \\
(00955)\end{array}$ & $\begin{array}{c}\text { Sulfate, } \\
\text { filtered, } \\
\text { mg/L } \\
(00945)\end{array}$ & $\begin{array}{c}\text { Dissolved } \\
\text { solids, } \\
\text { dried at } \\
180^{\circ} \mathrm{C}, \\
\text { filtered, } \\
\text { mg/L } \\
(70300) \\
\end{array}$ \\
\hline \multicolumn{7}{|c|}{ Sand and gravel wells } \\
\hline BM1405 & 122 & 31.5 & 0.13 & 7.89 & 12.9 & 186 \\
\hline D523 & 52 & 46.3 & E.05 & 5.47 & 8.97 & 154 \\
\hline SV534 & 23 & 29.7 & .04 & 4.04 & 10.2 & 108 \\
\hline SV555 & 79 & 30.7 & .07 & 5.78 & 7.51 & 139 \\
\hline SV884 & 92 & 52.3 & .09 & 7.67 & 15.6 & 199 \\
\hline \multicolumn{7}{|c|}{ Bedrock wells } \\
\hline D1191 & 85 & 14.7 & .09 & 7.46 & 6.18 & 116 \\
\hline SV551 & 115 & 5.63 & .11 & 10.6 & 93.0 & 235 \\
\hline SV1689 & 52 & 1.25 & .06 & 4.52 & 7.28 & 67 \\
\hline SV2320 & 32 & 1.30 & $<.08$ & 4.28 & 5.80 & 39 \\
\hline U2705 & 11 & 4.08 & $<.08$ & 3.30 & 4.50 & 34 \\
\hline
\end{tabular}

\footnotetext{
${ }^{1}$ BM, Broome County; D, Delaware County; SV, Sullivan County; U, Ulster County.
} 
Table 1-4. Concentrations of nutrients and organic carbon in groundwater samples collected in the Delaware River Basin, New York, 2010.

[N, nitrogen; P, phosphorus; mg/L, milligrams per liter; (00623), U.S. Geological Survey National Water Information System parameter code; <, less than; E, estimated concentration. Well locations are shown in figures 1 and 2]

\begin{tabular}{|c|c|c|c|c|c|c|}
\hline $\begin{array}{c}\text { Well } \\
\text { number }^{1}\end{array}$ & $\begin{array}{l}\text { Ammonia plus } \\
\text { organic-N, } \\
\text { filtered, } \\
\text { mg/L as } \mathrm{N} \\
(00623)\end{array}$ & $\begin{array}{l}\text { Ammonia, } \\
\text { filtered, } \\
\text { mg/L as N } \\
(00608)\end{array}$ & $\begin{array}{l}\text { Nitrate plus } \\
\text { nitrite, } \\
\text { filtered, } \\
\text { mg/L as N } \\
\text { (00631) }\end{array}$ & $\begin{array}{l}\text { Nitrite, } \\
\text { filtered, } \\
\text { mg/L as N } \\
(00613)\end{array}$ & $\begin{array}{c}\text { Ortho- } \\
\text { phosphate, } \\
\text { filtered, } \\
\text { mg/L as P } \\
(00671)\end{array}$ & $\begin{array}{c}\text { Organic } \\
\text { carbon, } \\
\text { unfiltered, } \\
\text { mg/L } \\
(00680)\end{array}$ \\
\hline \multicolumn{7}{|c|}{ Sand and gravel wells } \\
\hline BM1405 & $<0.05$ & $<0.010$ & 0.35 & 0.009 & 0.016 & $<0.3$ \\
\hline D523 & E.07 & $<.020$ & .70 & $<.002$ & .034 & 1.0 \\
\hline SV534 & .08 & $<.010$ & 1.54 & $<.001$ & .019 & .9 \\
\hline SV555 & $<.05$ & $<.010$ & .58 & $<.001$ & .010 & .4 \\
\hline SV884 & $<.10$ & $<.020$ & 1.33 & $<.002$ & .023 & E.4 \\
\hline \multicolumn{7}{|c|}{ Bedrock wells } \\
\hline D1191 & $<.10$ & $<.020$ & 1.25 & .004 & .009 & .6 \\
\hline SV551 & .12 & .046 & $<.04$ & $<.002$ & .013 & 1.2 \\
\hline SV1689 & $<.05$ & $<.010$ & .46 & $<.001$ & .009 & .9 \\
\hline SV2320 & $<.10$ & $<.020$ & .14 & $<.002$ & .038 & E.4 \\
\hline U2705 & $<.10$ & $<.020$ & .52 & $<.002$ & .015 & E.6 \\
\hline
\end{tabular}

${ }^{1}$ BM, Broome County; D, Delaware County; SV, Sullivan County; U, Ulster County.

Table 1-5. Concentrations of trace elements in groundwater samples collected in the Delaware River Basin, New York, 2010.

[ $\mu \mathrm{g} / \mathrm{L}$, micrograms per liter; (01105), U.S. Geological Survey National Water Information System parameter code; <, less than; E, estimated concentration. Bold values exceed one or more drinking-water standards. Well locations are shown in figures 1 and 2]

\begin{tabular}{|c|c|c|c|c|c|c|c|c|}
\hline $\begin{array}{c}\text { Well } \\
\text { number }^{1}\end{array}$ & $\begin{array}{c}\text { Aluminum, } \\
\text { unfiltered, } \\
\mu \mathrm{g} / \mathrm{L} \\
(01105)\end{array}$ & $\begin{array}{c}\text { Antimony, } \\
\text { unfiltered, } \\
\mu \mathrm{g} / \mathrm{L} \\
(01097) \\
\end{array}$ & $\begin{array}{c}\text { Arsenic, } \\
\text { unfiltered, } \\
\mu \mathrm{g} / \mathrm{L} \\
(01002) \\
\end{array}$ & $\begin{array}{c}\text { Barium, } \\
\text { unfiltered, } \\
\mu \mathrm{g} / \mathrm{L} \\
(01007)\end{array}$ & $\begin{array}{c}\text { Beryllium, } \\
\text { unfiltered, } \\
\mu \mathrm{g} / \mathrm{L} \\
(01012) \\
\end{array}$ & $\begin{array}{c}\text { Boron, } \\
\text { filtered, } \\
\mu \mathrm{g} / \mathrm{L} \\
(01020)\end{array}$ & $\begin{array}{c}\text { Cadmium, } \\
\text { unfiltered, } \\
\mu \mathrm{g} / \mathrm{L} \\
(01027) \\
\end{array}$ & $\begin{array}{c}\text { Chromium, } \\
\text { unfiltered, } \\
\mu \mathrm{g} / \mathrm{L} \\
(01034) \\
\end{array}$ \\
\hline \multicolumn{9}{|c|}{ Sand and gravel wells } \\
\hline BM1405 & $<3$ & 0.2 & 1.5 & 51.8 & $<0.02$ & 33 & $<0.05$ & 0.32 \\
\hline D523 & E5 & $<.4$ & .54 & 42.9 & $<.04$ & 19 & $<.04$ & $<.42$ \\
\hline SV534 & 13 & $<.2$ & .50 & 102 & .03 & 18 & .06 & .29 \\
\hline SV555 & $<3$ & $<.2$ & .47 & 138 & $<.02$ & 11 & $<.05$ & $<.21$ \\
\hline SV884 & E4 & $<.4$ & .57 & 49.7 & $<.04$ & 16 & $<.04$ & $<.42$ \\
\hline \multicolumn{9}{|c|}{ Bedrock wells } \\
\hline D1191 & 25 & $<.4$ & 1.9 & 98.1 & $<.04$ & 38 & $<.04$ & $<.42$ \\
\hline SV551 & 3 & $<.2$ & 1.1 & 31.6 & $<.02$ & 40 & $<.05$ & .22 \\
\hline SV1689 & 50 & $<.2$ & .62 & 23.1 & $<.02$ & 16 & $<.05$ & $<.21$ \\
\hline SV2320 & 200 & $<.4$ & .50 & 31.2 & $<.04$ & 3.9 & $<.04$ & .58 \\
\hline U2705 & 9 & $<.4$ & .28 & 41.8 & E.03 & 3.6 & $<.04$ & $<.42$ \\
\hline
\end{tabular}


Table 1-5. Concentrations of trace elements in groundwater samples collected in the Delaware River Basin, New York, 2010.-Continued

[ $\mu \mathrm{g} / \mathrm{L}$, micrograms per liter; (01037), U.S. Geological Survey National Water Information System parameter code; <, less than; $\mathrm{E}$, estimated concentration. Bold values exceed one or more drinking-water standards. Well locations are shown in figures 1 and 2]

\begin{tabular}{|c|c|c|c|c|c|c|c|c|}
\hline $\begin{array}{c}\text { Well } \\
\text { number }{ }^{1}\end{array}$ & $\begin{array}{c}\text { Cobalt, } \\
\text { unfiltered, } \\
\mu \mathrm{g} / \mathrm{L} \\
(01037)\end{array}$ & $\begin{array}{c}\text { Copper, } \\
\text { unfiltered, } \\
\mu \mathrm{g} / \mathrm{L} \\
(01042)\end{array}$ & $\begin{array}{l}\text { Iron, } \\
\text { filtered, } \\
\mu \mathrm{g} / \mathrm{L} \\
(01046)\end{array}$ & $\begin{array}{c}\text { Iron, } \\
\text { unfiltered, } \\
\mu \mathrm{g} / \mathrm{L} \\
(01045)\end{array}$ & $\begin{array}{c}\text { Lead, } \\
\text { unfiltered, } \\
\mu \mathrm{g} / \mathrm{L} \\
(01051)\end{array}$ & $\begin{array}{c}\text { Lithium, } \\
\text { unfiltered } \\
\mu \mathrm{g} / \mathrm{L} \\
(\mathbf{0 1 1 3 2})\end{array}$ & $\begin{array}{c}\text { Manganese, } \\
\text { filtered, } \\
\mu \mathrm{g} / \mathrm{L} \\
(01056)\end{array}$ & $\begin{array}{c}\text { Manganese, } \\
\text { unfiltered, } \\
\mu \mathrm{g} / \mathrm{L} \\
(01055)\end{array}$ \\
\hline \multicolumn{9}{|c|}{ Sand and gravel wells } \\
\hline BM1405 & 0.02 & 1.7 & $<3$ & 118 & 0.05 & 11.7 & 112 & 145 \\
\hline D523 & E.02 & 4.5 & E4 & E9 & .45 & E.2 & 21.8 & 23.0 \\
\hline SV534 & .04 & 25.5 & 13 & 19 & 1.80 & .3 & 3.6 & 3.2 \\
\hline SV555 & .03 & 1.2 & 19 & 24 & .48 & 2.6 & 11.3 & 12.2 \\
\hline SV884 & $<.04$ & 9.9 & 6 & 44 & .40 & 2.6 & 1.2 & 1.6 \\
\hline \multicolumn{9}{|c|}{ Bedrock wells } \\
\hline D1191 & .06 & 4.7 & $<6$ & 33 & .57 & 8.7 & 2.1 & 11.5 \\
\hline SV551 & $<.02$ & 1.2 & 5 & 10 & .25 & 14.0 & 5.3 & 5.0 \\
\hline SV1689 & .08 & 12.7 & 3 & 84 & .50 & 9.3 & $<.2$ & 3.4 \\
\hline SV2320 & .14 & 21.5 & E3 & 271 & 1.23 & 1.7 & .3 & 9.5 \\
\hline U2705 & $<.04$ & 36.8 & $<6$ & 11 & .58 & 1.0 & 4.0 & 4.8 \\
\hline
\end{tabular}

${ }^{1}$ BM, Broome County; D, Delaware County; SV, Sullivan County; U, Ulster County.

\begin{tabular}{|c|c|c|c|c|c|c|c|}
\hline $\begin{array}{c}\text { Well } \\
\text { number }{ }^{1}\end{array}$ & $\begin{array}{c}\text { Molybdenum, } \\
\text { unfiltered, } \\
\mu \mathrm{g} / \mathrm{L} \\
(01062)\end{array}$ & $\begin{array}{c}\text { Nickel, } \\
\text { unfiltered, } \\
\mu \mathrm{g} / \mathrm{L} \\
(01067)\end{array}$ & $\begin{array}{c}\text { Selenium, } \\
\text { unfiltered, } \\
\mu \mathrm{g} / \mathrm{L} \\
(01147)\end{array}$ & $\begin{array}{c}\text { Silver, } \\
\text { unfiltered, } \\
\mu \mathrm{g} / \mathrm{L} \\
(01077)\end{array}$ & $\begin{array}{c}\text { Strontium, } \\
\text { unfiltered, } \\
\mu \mathrm{g} / \mathrm{L} \\
(01082)\end{array}$ & $\begin{array}{c}\text { Zinc, } \\
\text { unfiltered, } \\
\mu \mathrm{g} / \mathrm{L} \\
(01092)\end{array}$ & $\begin{array}{c}\text { Uranium, } \\
\text { unfiltered, } \\
\mu \mathrm{g} / \mathrm{L} \\
(28011)\end{array}$ \\
\hline \multicolumn{8}{|c|}{ Sand and gravel wells } \\
\hline BM1405 & 0.2 & 0.20 & 0.15 & $<0.01$ & 306 & 18.8 & 0.501 \\
\hline D523 & $<.1$ & E.22 & .16 & .03 & 48.5 & 5.2 & E.014 \\
\hline SV534 & $<.1$ & 3.7 & .11 & $<.01$ & 53.2 & 14.8 & .035 \\
\hline SV555 & $<.1$ & $<.12$ & $<.05$ & $<.01$ & 166 & $<2.4$ & .094 \\
\hline SV884 & $<.1$ & $<.36$ & .26 & $<.02$ & 81.1 & 6.7 & .085 \\
\hline \multicolumn{8}{|c|}{ Bedrock wells } \\
\hline D1191 & 2.0 & E.23 & .29 & $<.02$ & 246 & 2.4 & .900 \\
\hline SV551 & .7 & .47 & $<.05$ & .06 & 3,680 & 5.2 & .549 \\
\hline SV1689 & .1 & .31 & .11 & $<.01$ & 276 & 2.9 & .311 \\
\hline SV2320 & $<.1$ & .70 & .11 & E.01 & 42.1 & 79.0 & .180 \\
\hline U2705 & $<.1$ & .38 & E.06 & E.01 & 20.9 & 2.7 & E.027 \\
\hline
\end{tabular}

${ }^{1}$ BM, Broome County; D, Delaware County; SV, Sullivan County; U, Ulster County. 
Table 1-6. Concentrations of pesticides detected in groundwater samples collected in the Delaware River Basin, New York, 2010.

[ $\mu \mathrm{g} / \mathrm{L}$, micrograms per liter; CIAT, 2-chloro-4-isopropylamino-6-amino-s-triazine (04040), U.S. Geological Survey National Water Information System parameter code; <, less than; E, estimated concentration; M, presence verified but not quantified. Well locations are shown in figures 1 and 2]

\begin{tabular}{|c|c|c|c|c|}
\hline $\begin{array}{c}\text { Well } \\
\text { number }^{1}\end{array}$ & $\begin{array}{c}\text { CIAT, } \\
\text { filtered, } \\
\mu \mathrm{g} / \mathrm{L} \\
(04040)\end{array}$ & $\begin{array}{c}\text { Atrazine, } \\
\text { filtered, } \\
\mu \mathrm{g} / \mathrm{L} \\
(39632)\end{array}$ & $\begin{array}{c}\text { Prometon, } \\
\text { filtered, } \\
\mu \mathrm{g} / \mathrm{L} \\
(04037) \\
\end{array}$ & $\begin{array}{c}\text { Simazine, } \\
\text { filtered, } \\
\mu \mathrm{g} / \mathrm{L} \\
(04035)\end{array}$ \\
\hline \multicolumn{5}{|c|}{ Sand and gravel wells } \\
\hline BM1405 & $<0.006$ & $<0.008$ & $<0.01$ & $<0.006$ \\
\hline D523 & E.008 & E.003 & $\mathrm{M}$ & E.002 \\
\hline SV534 & E.077 & .059 & $<.01$ & .003 \\
\hline SV555 & $<.006$ & $<.008$ & $<.01$ & $<.006$ \\
\hline SV884 & E.023 & .009 & $<.01$ & $<.006$ \\
\hline \multicolumn{5}{|c|}{ Bedrock wells } \\
\hline D1191 & E.003 & $<.007$ & $<.01$ & $<.006$ \\
\hline SV551 & $<.006$ & $<.008$ & $<.01$ & $<.006$ \\
\hline SV1689 & $<.006$ & $<.008$ & $<.01$ & $<.006$ \\
\hline SV2320 & $<.014$ & $<.007$ & $<.01$ & $<.006$ \\
\hline U2705 & $<.014$ & $<.007$ & $<.01$ & $<.006$ \\
\hline
\end{tabular}

${ }^{1}$ BM, Broome County; D, Delaware County; SV, Sullivan County; U, Ulster County.

Table 1-7. Concentrations of volatile organic compounds detected in groundwater samples collected in the Delaware River Basin, New York, 2010.

[ $\mu \mathrm{g} / \mathrm{L}$, micrograms per liter; (32101), U.S. Geological Survey National Water Information System parameter code; <, less than. Well locations are shown in figures 1 and 2]

\begin{tabular}{|c|c|c|c|c|c|}
\hline $\begin{array}{c}\text { Well } \\
\text { number }^{1}\end{array}$ & $\begin{array}{c}\text { Bromodichloro- } \\
\text { methane, } \\
\text { unfiltered, } \\
\mu \mathrm{g} / \mathrm{L} \\
(32101)\end{array}$ & $\begin{array}{c}\text { Tribromo- } \\
\text { methane, } \\
\text { unfiltered, } \\
\mu \mathrm{g} / \mathrm{L} \\
(32104)\end{array}$ & $\begin{array}{c}\text { Dibromochloro- } \\
\text { methane, } \\
\text { unfiltered, } \\
\mu \mathrm{g} / \mathrm{L} \\
(32105)\end{array}$ & $\begin{array}{c}\text { Tetrachloro- } \\
\text { methane, } \\
\text { unfiltered, } \\
\mu \mathrm{g} / \mathrm{L} \\
(32102)\end{array}$ & $\begin{array}{c}\text { Trichloro- } \\
\text { methane, } \\
\text { unfiltered, } \\
\mu \mathrm{g} / \mathrm{L} \\
(32106)\end{array}$ \\
\hline \multicolumn{6}{|c|}{ Sand and gravel wells } \\
\hline BM1405 & $<0.1$ & $<0.2$ & $<0.2$ & $<0.2$ & $<0.1$ \\
\hline D523 & $<.1$ & $<.2$ & $<.2$ & $<.2$ & $<.1$ \\
\hline SV534 & $<.1$ & $<.2$ & $<.2$ & $<.2$ & $<.1$ \\
\hline SV555 & $<.1$ & $<.2$ & $<.2$ & $<.2$ & $<.1$ \\
\hline SV884 & .5 & 1.0 & 1.2 & .8 & .3 \\
\hline \multicolumn{6}{|c|}{ Bedrock wells } \\
\hline D1191 & $<.1$ & $<.2$ & $<.2$ & $<.2$ & $<.1$ \\
\hline SV551 & $<.1$ & $<.2$ & $<.2$ & $<.2$ & $<.1$ \\
\hline SV1689 & $<.1$ & $<.2$ & $<.2$ & $<.2$ & .1 \\
\hline SV2320 & $<.1$ & $<.2$ & $<.2$ & $<.2$ & $<.1$ \\
\hline U2705 & $<.1$ & $<.2$ & $<.2$ & $<.2$ & $<.1$ \\
\hline
\end{tabular}

\footnotetext{
${ }^{1}$ BM, Broome County; D, Delaware County; SV, Sullivan County; U, Ulster County.
} 
Table 1-8. Activities of radionuclides in groundwater samples from the Delaware River Basin, New York, 2010. [pCi/L, picocuries per liter; (01519), USGS National Water Information System parameter code; <, less than. Bold values equal or exceed one or more existing or proposed drinking-water standards. Well locations are shown in figures 1 and 2]

\begin{tabular}{lccc}
\hline Well & $\begin{array}{c}\text { Gross alpha, } \\
\text { radioactivity, } \\
\text { unfiltered, } \\
\text { pCi/L } \\
\text { (01519) }\end{array}$ & $\begin{array}{c}\text { Gross beta } \\
\text { radioactivity, } \\
\text { unfiltered, } \\
\text { pCi/L } \\
\text { (85817) }\end{array}$ & $\begin{array}{c}\text { Radon-222, } \\
\text { unfiltered, } \\
\text { pCi/L } \\
\text { (82303) }\end{array}$ \\
\hline \multicolumn{2}{l}{ Sand and gravel wells } & & \\
\hline BM1405 & 1.0 & $<1.1$ & $\mathbf{9 3 0}$ \\
D523 & $<.79$ & 2.2 & $\mathbf{8 7 0}$ \\
SV534 & $<.67$ & 2.0 & $\mathbf{4 1 0}$ \\
SV555 & 1.2 & 1.4 & $\mathbf{8 7 0}$ \\
SV884 & $<.96$ & 2.5 & $\mathbf{6 6 0}$ \\
\hline Bedrock wells & & & \\
\hline D1191 & 1.7 & 1.1 & $\mathbf{8 2 0}$ \\
SV551 & 1.0 & $<1.4$ & $\mathbf{7 9 0}$ \\
SV1689 & .9 & $<1$ & $\mathbf{1 , 2 1 0}$ \\
SV2320 & .5 & $<1.3$ & $\mathbf{1 , 6 7 0}$ \\
U2705 & .3 & $<.86$ & $\mathbf{1 , 0 9 0}$ \\
\hline
\end{tabular}

${ }^{1}$ BM, Broome County; D, Delaware County; SV, Sullivan County; U, Ulster County.

Table 1-9. Bacteria in groundwater samples collected in the Delaware River Basin, New York, 2010.

[CFU, colony-forming unit; mL, milliliter; MPN, most probable number; (99596), U.S. Geological Survey National Water Information System parameter code; --, not analyzed; <, less than; U, absent; M, present. Bold values indicate detections of coliform bacteria. Well locations are shown in figures 1 and 2]

\begin{tabular}{|c|c|c|c|c|c|c|c|}
\hline $\begin{array}{c}\text { Well } \\
\text { number }{ }^{1}\end{array}$ & $\begin{array}{c}\text { Escherichia coli, } \\
\text { Colilert, } \\
\text { unfiltered, } \\
\text { PresencelAbsence } \\
\text { (99596) }\end{array}$ & $\begin{array}{c}\text { Escherichia } \\
\text { coli, } \\
\text { defined } \\
\text { substrate, } \\
\text { unfiltered, } \\
\text { MPN/100mL } \\
(50468)\end{array}$ & $\begin{array}{c}\text { Fecal } \\
\text { coliform, } \\
\text { membrane } \\
\text { filtration, } \\
\text { unfiltered, } \\
\text { CFU/100mL } \\
(61215)\end{array}$ & $\begin{array}{l}\text { Heterotrophic } \\
\text { plate count, } \\
\text { unfiltered, } \\
\text { CFU/mL } \\
(31692)\end{array}$ & $\begin{array}{c}\text { Total coliform, } \\
\text { Colilert, } \\
\text { unfiltered, } \\
\text { PresencelAbsence } \\
\text { (99595) }\end{array}$ & $\begin{array}{c}\text { Total } \\
\text { coliform, } \\
\text { defined } \\
\text { substrate, } \\
\text { unfiltered, } \\
\text { MPN/100mL } \\
(50569)\end{array}$ & $\begin{array}{c}\text { Total } \\
\text { coliform, } \\
\text { membrane } \\
\text { filtration, } \\
\text { unfiltered, } \\
\text { CFU/100mL } \\
\text { (61213) }\end{array}$ \\
\hline \multicolumn{8}{|c|}{ Sand and gravel wells } \\
\hline BM1405 & -- & $<1$ & $<5$ & 1 & -- & $<1$ & $<20$ \\
\hline D523 & -- & $<1$ & $<5$ & 7,000 & -- & 15 & 50 \\
\hline SV534 & -- & $<1$ & $<5$ & 1 & -- & 3 & -- \\
\hline SV555 & -- & $<1$ & $<5$ & 2 & -- & $<1$ & -- \\
\hline SV884 & $\mathrm{U}$ & -- & -- & -- & $\mathrm{U}$ & -- & -- \\
\hline \multicolumn{8}{|c|}{ Bedrock wells } \\
\hline D1191 & $\mathrm{U}$ & $<1$ & $<5$ & $<1$ & $\mathbf{M}$ & -- & 33 \\
\hline SV551 & -- & $<1$ & $<5$ & 5 & -- & $<1$ & -- \\
\hline SV1689 & -- & $<1$ & $<5$ & 6 & -- & 70 & -- \\
\hline SV2320 & -- & $<1$ & $<5$ & 1 & -- & $<1$ & $<20$ \\
\hline U2705 & -- & $<1$ & $<5$ & 2 & -- & 3 & $<20$ \\
\hline
\end{tabular}

\footnotetext{
${ }^{1}$ BM, Broome County; D, Delaware County; SV, Sullivan County; U, Ulster County.
} 
Table 1-10. Physiochemical properties and concentrations of major ions, nutrients, and bacteria in groundwater samples collected in the Delaware River Basin, New York, 2005 and 2010.

[NWIS, National Water Information System; mg/L, milligrams per liter, $\mu \mathrm{S} / \mathrm{cm}$, microsiemens per centimeter at 25 degrees Celsius, CaCO ${ }_{3}$, calcium carbonate; ${ }^{\circ} \mathrm{C}$, degrees Celsius; $\mathrm{N}$, nitrogen; $\mathrm{P}$, phosphorus; $\mathrm{CFU}$, colony-forming unit; mL, milliliter; <, less than, E, estimated concentration; --, not analyzed; U, not detected]

\begin{tabular}{|c|c|c|c|}
\hline $\begin{array}{c}\text { U.S. } \\
\text { Geological } \\
\text { Survey } \\
\text { NWIS } \\
\text { parameter }\end{array}$ & & Well & \\
\hline code & Constituent & 2005 & 2010 \\
\hline 00080 & Color, filtered, platinum-cobalt units & 8 & $<1$ \\
\hline 00300 & Dissolved oxygen, unfiltered, mg/L & 7.2 & 7.2 \\
\hline 00400 & $\mathrm{pH}$, unfiltered & 6.9 & 6.9 \\
\hline 00095 & Specific conductance, unfiltered, $\mu \mathrm{S} / \mathrm{cm}$ & 96 & 99 \\
\hline 00010 & Temperature, unfiltered, degrees Celsius & 8.6 & 9.1 \\
\hline 00900 & Hardness, filtered, $\mathrm{mg} / \mathrm{L}$ as $\mathrm{CaCO}_{3}$ & 40.1 & 41.1 \\
\hline 00915 & Calcium, filtered, mg/L & 13.2 & 13.5 \\
\hline 00925 & Magnesium, filtered, mg/L & 1.74 & 1.79 \\
\hline 00935 & Potassium, filtered, mg/L & .70 & .73 \\
\hline 00930 & Sodium, filtered, mg/L & 4.75 & 3.60 \\
\hline 90410 & $\begin{array}{l}\text { Acid neutralizing capacity, unfiltered, fixed end } \\
\text { point, lab, mg/L as } \mathrm{CaCO}_{3}\end{array}$ & 38 & 42 \\
\hline 29801 & $\begin{array}{l}\text { Alkalinity, filtered, fixed end point, laboratory, } \\
\mathrm{mg} / \mathrm{L} \text { as } \mathrm{CaCO}_{3}\end{array}$ & 38 & 43 \\
\hline 29805 & $\begin{array}{l}\text { Bicarbonate, filtered, fixed end point, laboratory, } \\
\mathrm{mg} / \mathrm{L}\end{array}$ & 46 & 52 \\
\hline 00940 & Chloride, filtered, mg/L & 1.08 & 1.25 \\
\hline 00950 & Fluoride, filtered, mg/L & E.05 & .06 \\
\hline 00955 & Silica, filtered, mg/L & 4.72 & 4.52 \\
\hline 00945 & Sulfate, filtered, mg/L & 7.29 & 7.28 \\
\hline 70300 & Dissolved solids, dried at $180^{\circ} \mathrm{C}$, filtered, $\mathrm{mg} / \mathrm{L}$ & 60 & 67 \\
\hline 00623 & Ammonia plus organic- $\mathrm{N}$, filtered, $\mathrm{mg} / \mathrm{L}$ as $\mathrm{N}$ & $<.10$ & $<.05$ \\
\hline 00608 & Ammonia, filtered, mg/L as $\mathrm{N}$ & $<.04$ & $<.010$ \\
\hline 00631 & Nitrate plus nitrite, filtered, $\mathrm{mg} / \mathrm{L}$ as $\mathrm{N}$ & .53 & .46 \\
\hline 00613 & Nitrite, filtered, mg/L as $\mathrm{N}$ & $<.008$ & $<.001$ \\
\hline 00671 & Orthophosphate, filtered, $\mathrm{mg} / \mathrm{L}$ as $\mathrm{P}$ & $<.02$ & .009 \\
\hline 00680 & Organic carbon, unfiltered, mg/L & $<1.0$ & .9 \\
\hline 31691 & Escherichia coli, unfiltered, CFU per $100 \mathrm{~mL}$ & -- & $\mathrm{U}$ \\
\hline 61215 & Fecal coliform, unfiltered, CFU per 100 mL & $<1$ & $<5$ \\
\hline \multirow[t]{2}{*}{31692} & Heterotrophic plate count, unfiltered, CFU per mL & 86 & 6 \\
\hline & Total coliform, unfiltered, CFU per $100 \mathrm{~mL}$ & 3 & 70 \\
\hline
\end{tabular}


Table 1-11. Concentrations of trace elements and radionuclides in groundwater samples in the Delaware River Basin, New York, 2005 and 2010.

[NWIS, National Water Information System; $\mu \mathrm{g} / \mathrm{L}$, micrograms per liter, pCi/L, picocuries per liter; <, less than, E, estimated concentration] U.S.

\begin{tabular}{|c|c|c|c|}
\hline \multirow{2}{*}{$\begin{array}{l}\text { Geological } \\
\text { Survey } \\
\text { NWIS } \\
\text { parameter } \\
\text { code } \\
\end{array}$} & \multirow[b]{2}{*}{ Constituent } & \multicolumn{2}{|c|}{ Well SV1689 } \\
\hline & & 2005 & 2010 \\
\hline 01105 & Aluminum, unfiltered, $\mu \mathrm{g} / \mathrm{L}$ & 1,100 & 50 \\
\hline 01097 & Antimony, unfiltered, $\mu \mathrm{g} / \mathrm{L}$ & E.1 & $<.2$ \\
\hline 01002 & Arsenic, unfiltered, $\mu \mathrm{g} / \mathrm{L}$ & 1.5 & .62 \\
\hline 01007 & Barium, unfiltered, $\mu \mathrm{g} / \mathrm{L}$ & 36.6 & 23.1 \\
\hline 01012 & Beryllium, unfiltered, $\mu \mathrm{g} / \mathrm{L}$ & .09 & $<.02$ \\
\hline 01020 & Boron, filtered, $\mu \mathrm{g} / \mathrm{L}$ & 15 & 16 \\
\hline 01027 & Cadmium, unfiltered, $\mu \mathrm{g} / \mathrm{L}$ & .05 & $<.05$ \\
\hline 01034 & Chromium, unfiltered, $\mu \mathrm{g} / \mathrm{L}$ & 1.9 & $<.21$ \\
\hline 01037 & Cobalt, unfiltered, $\mu \mathrm{g} / \mathrm{L}$ & 2.24 & .08 \\
\hline 01042 & Copper, unfiltered, $\mu \mathrm{g} / \mathrm{L}$ & 16.0 & 12.7 \\
\hline 01046 & Iron, filtered, $\mu \mathrm{g} / \mathrm{L}$ & E4 & 3 \\
\hline 01045 & Iron, unfiltered, $\mu \mathrm{g} / \mathrm{L}$ & 2,150 & 84 \\
\hline 01051 & Lead, unfiltered, $\mu \mathrm{g} / \mathrm{L}$ & 4.64 & .50 \\
\hline 01132 & Lithium, unfiltered, $\mu \mathrm{g} / \mathrm{L}$ & 10.5 & 9.3 \\
\hline 01056 & Manganese, filtered, $\mu \mathrm{g} / \mathrm{L}$ & E.4 & $<.2$ \\
\hline 01055 & Manganese, unfiltered, $\mu \mathrm{g} / \mathrm{L}$ & 141 & 3.4 \\
\hline 71900 & Mercury, unfiltered, $\mu \mathrm{g} / \mathrm{L}$ & $<.010$ & $<.005$ \\
\hline 01062 & Molybdenum, unfiltered, $\mu \mathrm{g} / \mathrm{L}$ & E.1 & .1 \\
\hline 01067 & Nickel, unfiltered, $\mu \mathrm{g} / \mathrm{L}$ & 3.27 & .31 \\
\hline 01147 & Selenium, unfiltered, $\mu \mathrm{g} / \mathrm{L}$ & E.06 & .11 \\
\hline 01077 & Silver, unfiltered, $\mu \mathrm{g} / \mathrm{L}$ & $<.16$ & $<.01$ \\
\hline 01082 & Strontium, unfiltered, $\mu \mathrm{g} / \mathrm{L}$ & 220 & 276 \\
\hline 01059 & Thallium, unfiltered, $\mu \mathrm{g} / \mathrm{L}$ & $<.18$ & $<.06$ \\
\hline 01092 & Zinc, unfiltered, $\mu \mathrm{g} / \mathrm{L}$ & 12 & 2.9 \\
\hline 82303 & Radon-222, unfiltered, pCi/L & 1,280 & 1,210 \\
\hline 28011 & Uranium, unfiltered, $\mu \mathrm{g} / \mathrm{L}$ & .539 & .311 \\
\hline
\end{tabular}


Table 1-12. Concentrations of pesticides in groundwater samples collected in the Delaware River Basin, New York, 2005 and 2010.

[NWIS, National Water Information System; $\mu \mathrm{g} / \mathrm{L}$, micrograms per liter; $<$, less than]

U.S.

Geological

Survey

NWIS

parameter

Well SV1689

\begin{tabular}{|c|c|c|c|}
\hline code & Constituent & 2005 & 2010 \\
\hline 82660 & 2,6-Diethylaniline, filtered, $\mu \mathrm{g} / \mathrm{L}$ & $<0.006$ & $<0.006$ \\
\hline 04040 & $\begin{array}{l}\text { 2-Chloro-4-isopropylamino-6-amino-s- } \\
\text { triazine (CIAT), filtered, } \mu \mathrm{g} / \mathrm{L}\end{array}$ & $<.006$ & $<.006$ \\
\hline 49260 & Acetochlor, filtered, $\mu \mathrm{g} / \mathrm{L}$ & $<.006$ & $<.010$ \\
\hline 46342 & Alachlor, filtered, $\mu \mathrm{g} / \mathrm{L}$ & $<.005$ & $<.008$ \\
\hline 34253 & alpha-HCH, filtered, $\mu \mathrm{g} / \mathrm{L}$ & $<.005$ & $<.004$ \\
\hline 39632 & Atrazine, filtered, $\mu \mathrm{g} / \mathrm{L}$ & $<.007$ & $<.008$ \\
\hline 82686 & Azinphos-methyl, filtered, $\mu \mathrm{g} / \mathrm{L}$ & $<.050$ & $<.120$ \\
\hline 82673 & Benfluralin, filtered, $\mu \mathrm{g} / \mathrm{L}$ & $<.010$ & $<.014$ \\
\hline 04028 & Butylate, filtered, $\mu \mathrm{g} / \mathrm{L}$ & $<.004$ & $<.004$ \\
\hline 82680 & Carbaryl, filtered, $\mu \mathrm{g} / \mathrm{L}$ & $<.041$ & $<.060$ \\
\hline 82674 & Carbofuran, filtered, $\mu \mathrm{g} / \mathrm{L}$ & $<.020$ & $<.060$ \\
\hline 38933 & Chlorpyrifos, filtered, $\mu \mathrm{g} / \mathrm{L}$ & $<.005$ & $<.004$ \\
\hline 82687 & cis-Permethrin, filtered, $\mu \mathrm{g} / \mathrm{L}$ & $<.006$ & $<.010$ \\
\hline 04041 & Cyanazine, filtered, $\mu \mathrm{g} / \mathrm{L}$ & $<.018$ & $<.022$ \\
\hline 82682 & DCPA, filtered, $\mu \mathrm{g} / \mathrm{L}$ & $<.003$ & $<.008$ \\
\hline 62170 & Desulfinylfipronil, filtered, $\mu \mathrm{g} / \mathrm{L}$ & $<.012$ & $<.012$ \\
\hline 39572 & Diazinon, filtered, $\mu \mathrm{g} / \mathrm{L}$ & $<.005$ & $<.006$ \\
\hline 39381 & Dieldrin, filtered, $\mu \mathrm{g} / \mathrm{L}$ & $<.009$ & $<.008$ \\
\hline 82677 & Disulfoton, filtered, $\mu \mathrm{g} / \mathrm{L}$ & $<.02$ & $<.04$ \\
\hline 82668 & EPTC, filtered, $\mu \mathrm{g} / \mathrm{L}$ & $<.004$ & $<.006$ \\
\hline 82663 & Ethalfluralin, filtered, $\mu \mathrm{g} / \mathrm{L}$ & $<.009$ & $<.006$ \\
\hline 82672 & Ethoprop, filtered, $\mu \mathrm{g} / \mathrm{L}$ & $<.005$ & $<.016$ \\
\hline 62169 & Desulfinylfipronil amide, filtered, $\mu \mathrm{g} / \mathrm{L}$ & $<.029$ & $<.029$ \\
\hline 62167 & Fipronil sulfide, filtered, $\mu \mathrm{g} / \mathrm{L}$ & $<.013$ & $<.012$ \\
\hline 62168 & Fipronil sulfone, filtered, $\mu \mathrm{g} / \mathrm{L}$ & $<.024$ & $<.024$ \\
\hline 62166 & Fipronil, filtered, $\mu \mathrm{g} / \mathrm{L}$ & $<.016$ & $<.018$ \\
\hline 04095 & Fonofos, filtered, $\mu \mathrm{g} / \mathrm{L}$ & $<.003$ & $<.005$ \\
\hline 39341 & Lindane, filtered, $\mu \mathrm{g} / \mathrm{L}$ & $<.004$ & $<.004$ \\
\hline 82666 & Linuron, filtered, $\mu \mathrm{g} / \mathrm{L}$ & $<.035$ & $<.060$ \\
\hline 39532 & Malathion, filtered, $\mu \mathrm{g} / \mathrm{L}$ & $<.027$ & $<.016$ \\
\hline
\end{tabular}


Table 1-12. Concentrations of pesticides in groundwater samples collected in the Delaware River Basin, New York, 2005 and 2010.-Continued

[NWIS, National Water Information System; $\mu \mathrm{g} / \mathrm{L}$, micrograms per liter; $<$, less than]

U.S.

\begin{tabular}{|c|c|c|c|}
\hline \multirow{2}{*}{$\begin{array}{c}\text { Geological } \\
\text { Survey } \\
\text { NWIS } \\
\text { parameter } \\
\text { code }\end{array}$} & \multirow[b]{2}{*}{ Constituent } & \multicolumn{2}{|c|}{ Well SV1689 } \\
\hline & & 2005 & 2010 \\
\hline 82667 & Methyl parathion, filtered, $\mu \mathrm{g} / \mathrm{L}$ & $<0.015$ & $<0.008$ \\
\hline 39415 & Metolachlor, filtered, $\mu \mathrm{g} / \mathrm{L}$ & $<.006$ & $<.014$ \\
\hline 82630 & Metribuzin, filtered, $\mu \mathrm{g} / \mathrm{L}$ & $<.006$ & $<.012$ \\
\hline 82671 & Molinate, filtered, $\mu \mathrm{g} / \mathrm{L}$ & $<.003$ & $<.004$ \\
\hline 82684 & Napropamide, filtered, $\mu \mathrm{g} / \mathrm{L}$ & $<.007$ & $<.008$ \\
\hline 34653 & $p, p^{\prime}$-DDE, filtered, $\mu \mathrm{g} / \mathrm{L}$ & $<.003$ & $<.002$ \\
\hline 39542 & Parathion, filtered, $\mu \mathrm{g} / \mathrm{L}$ & $<.010$ & $<.020$ \\
\hline 82669 & Pebulate, filtered, $\mu \mathrm{g} / \mathrm{L}$ & $<.004$ & $<.016$ \\
\hline 82683 & Pendimethalin, filtered, $\mu \mathrm{g} / \mathrm{L}$ & $<.022$ & $<.012$ \\
\hline 82664 & Phorate, filtered, $\mu \mathrm{g} / \mathrm{L}$ & $<.011$ & $<.020$ \\
\hline 04037 & Prometon, filtered, $\mu \mathrm{g} / \mathrm{L}$ & $<.01$ & $<.01$ \\
\hline 82676 & Propyzamide, filtered, $\mu \mathrm{g} / \mathrm{L}$ & $<.004$ & $<.004$ \\
\hline 04024 & Propachlor, filtered, $\mu \mathrm{g} / \mathrm{L}$ & $<.025$ & $<.006$ \\
\hline 82679 & Propanil, filtered, $\mu \mathrm{g} / \mathrm{L}$ & $<.011$ & $<.010$ \\
\hline 82685 & Propargite, filtered, $\mu \mathrm{g} / \mathrm{L}$ & $<.02$ & $<.02$ \\
\hline 04035 & Simazine, filtered, $\mu \mathrm{g} / \mathrm{L}$ & $<.005$ & $<.006$ \\
\hline 82670 & Tebuthiuron, filtered, $\mu \mathrm{g} / \mathrm{L}$ & $<.02$ & $<.03$ \\
\hline 82665 & Terbacil, filtered, $\mu \mathrm{g} / \mathrm{L}$ & $<.034$ & $<.024$ \\
\hline 82675 & Terbufos, filtered, $\mu \mathrm{g} / \mathrm{L}$ & $<.02$ & $<.02$ \\
\hline 82681 & Thiobencarb, filtered, $\mu \mathrm{g} / \mathrm{L}$ & $<.010$ & $<.016$ \\
\hline 82678 & Triallate, filtered, $\mu \mathrm{g} / \mathrm{L}$ & $<.006$ & $<.005$ \\
\hline 82661 & Trifluralin, filtered, $\mu \mathrm{g} / \mathrm{L}$ & $<.009$ & $<.018$ \\
\hline
\end{tabular}


Table 1-13. Concentrations of volatile organic compounds in groundwater samples collected in the Delaware River Basin, New York, 2005 and 2010.

[NWIS, National Water Information System; $\mu \mathrm{g} / \mathrm{L}$, micrograms per liter, <, less than. Bold values indicate detected concentrations]

U.S.

Geological

Survey

NWIS

parameter

code

Constituent

Well SV1689

\begin{tabular}{|c|c|c|c|}
\hline 34506 & 1,1,1-Trichloroethane, unfiltered, $\mu \mathrm{g} / \mathrm{L}$ & $<0.1$ & $<0.1$ \\
\hline 77652 & 1,1,2-Trichloro-1,2,2-trifluoroethane (CFC-113), unfiltered, $\mu \mathrm{g} / \mathrm{L}$ & $<.1$ & $<.1$ \\
\hline 34496 & 1,1-Dichloroethane, unfiltered, $\mu \mathrm{g} / \mathrm{L}$ & $<.1$ & $<.1$ \\
\hline 34501 & 1,1-Dichloroethene, unfiltered, $\mu \mathrm{g} / \mathrm{L}$ & $<.1$ & $<.1$ \\
\hline 34536 & 1,2-Dichlorobenzene, unfiltered, $\mu \mathrm{g} / \mathrm{L}$ & $<.1$ & $<.1$ \\
\hline 32103 & 1,2-Dichloroethane, unfiltered, $\mu \mathrm{g} / \mathrm{L}$ & $<.2$ & $<.2$ \\
\hline 34541 & 1,2-Dichloropropane, unfiltered, $\mu \mathrm{g} / \mathrm{L}$ & $<.1$ & $<.1$ \\
\hline 34566 & 1,3-Dichlorobenzene, unfiltered, $\mu \mathrm{g} / \mathrm{L}$ & $<.1$ & $<.1$ \\
\hline 34571 & 1,4-Dichlorobenzene, unfiltered, $\mu \mathrm{g} / \mathrm{L}$ & $<.1$ & $<.1$ \\
\hline 34030 & Benzene, unfiltered, $\mu \mathrm{g} / \mathrm{L}$ & $<.1$ & $<.1$ \\
\hline 32101 & Bromodichloromethane, unfiltered, $\mu \mathrm{g} / \mathrm{L}$ & $<.1$ & $<.1$ \\
\hline 32104 & Tribromomethane, unfiltered, $\mu \mathrm{g} / \mathrm{L}$ & $<.2$ & $<.2$ \\
\hline 34301 & Chlorobenzene, unfiltered, $\mu \mathrm{g} / \mathrm{L}$ & $<.1$ & $<.1$ \\
\hline 77093 & cis-1,2-Dichloroethene, unfiltered, $\mu \mathrm{g} / \mathrm{L}$ & $<.1$ & $<.1$ \\
\hline 32105 & Dibromochloromethane, unfiltered, $\mu \mathrm{g} / \mathrm{L}$ & $<.2$ & $<.2$ \\
\hline 34668 & Dichlorodifluoromethane, unfiltered, $\mu \mathrm{g} / \mathrm{L}$ & $<.2$ & $<.2$ \\
\hline 34423 & Dichloromethane, unfiltered, $\mu \mathrm{g} / \mathrm{L}$ & $<.2$ & $<.2$ \\
\hline 81576 & Diethyl ether, unfiltered, $\mu \mathrm{g} / \mathrm{L}$ & $<.2$ & $<.2$ \\
\hline 81577 & Diisopropyl ether, unfiltered, $\mu \mathrm{g} / \mathrm{L}$ & $<.2$ & $<.2$ \\
\hline 34371 & Ethylbenzene, unfiltered, $\mu \mathrm{g} / \mathrm{L}$ & $<.1$ & $<.1$ \\
\hline 50005 & Methyl tert-pentyl ether, unfiltered, $\mu \mathrm{g} / \mathrm{L}$ & $<.2$ & $<.2$ \\
\hline 85795 & $m$ - + p-Xylene, unfiltered, $\mu \mathrm{g} / \mathrm{L}$ & $<.2$ & $<.2$ \\
\hline 77135 & $o$-Xylene, unfiltered, $\mu \mathrm{g} / \mathrm{L}$ & $<.1$ & $<.1$ \\
\hline 77128 & Styrene, unfiltered, $\mu \mathrm{g} / \mathrm{L}$ & $<.1$ & $<.1$ \\
\hline 50004 & tert-Butyl ethyl ether, unfiltered, $\mu \mathrm{g} / \mathrm{L}$ & $<.1$ & $<.1$ \\
\hline 78032 & Methyl tert-butyl ether (MTBE), unfiltered, $\mu \mathrm{g} / \mathrm{L}$ & $<.2$ & $<.2$ \\
\hline 34475 & Tetrachloroethene, unfiltered, $\mu \mathrm{g} / \mathrm{L}$ & $<.1$ & $<.1$ \\
\hline 32102 & Tetrachloromethane, unfiltered, $\mu \mathrm{g} / \mathrm{L}$ & $<.2$ & $<.2$ \\
\hline 34010 & Toluene, unfiltered, $\mu \mathrm{g} / \mathrm{L}$ & $<.1$ & $<.1$ \\
\hline 34546 & trans-1,2-Dichloroethene, unfiltered, $\mu \mathrm{g} / \mathrm{L}$ & $<.1$ & $<.1$ \\
\hline 39180 & Trichloroethene, unfiltered, $\mu \mathrm{g} / \mathrm{L}$ & $<.1$ & $<.1$ \\
\hline 34488 & Trichlorofluoromethane (CFC-11), unfiltered, $\mu \mathrm{g} / \mathrm{L}$ & $<.2$ & $<.2$ \\
\hline 32106 & Trichloromethane, unfiltered, $\mu \mathrm{g} / \mathrm{L}$ & $<.1$ & .1 \\
\hline 39175 & Vinyl chloride, unfiltered, $\mu \mathrm{g} / \mathrm{L}$ & $<.2$ & $<.2$ \\
\hline
\end{tabular}




\section{Appendix 2: Results of Water-Sample Analyses in the St. Lawrence River Basin}

The following tables summarize results of the chemical analyses of the 20 samples collected in the St. Lawrence River Basin in New York from August through October 2010.

Table 2-1. Constituents that were not detected in groundwater samples collected in the St. Lawrence River Basin, New York, 2010.

Table 2-2. Physiochemical properties of groundwater samples collected in the St. Lawrence River Basin, New York, 2010.

Table 2-3. Concentrations of major ions in groundwater samples collected in the St. Lawrence River Basin, New

York, 2010.

Table 2-4. Concentrations of nutrients and organic carbon in groundwater samples collected in the St. Lawrence River Basin, New York, 2010.

Table 2-5. Concentrations of trace elements in groundwater samples collected in the St. Lawrence River Basin, New York, 2010.

Table 2-6. Concentrations of pesticides detected in groundwater samples collected in the St. Lawrence River Basin, New York, 2010.

Table 2-7. Concentrations of volatile organic compounds detected in groundwater samples collected in the St. Lawrence River Basin, New York, 2010.

Table 2-8. Activities of radionuclides in groundwater samples from the St. Lawrence River Basin, New York, 2010.

Table 2-9. Bacteria in groundwater samples collected in the St. Lawrence River Basin, New York, 2010.

Table 2-10. Physiochemical properties and concentrations of major ions, nutrients, and bacteria in groundwater samples collected in the St. Lawrence River Basin, New York, 2005 and 2010.

Table 2-11. Concentrations of trace elements and radionuclides in groundwater samples collected in the St. Lawrence River Basin, New York, 2005 and 2010

Table 2-12. Concentrations of pesticides in groundwater samples collected in St. Lawrence River Basin, New York, 2005 and 2010.

Table 2-13. Concentrations of volatile organic compounds in groundwater samples collected in the St. Lawrence

River Basin, New York, 2005 and 2010. 
Table 2-1. Constituents that were not detected in groundwater samples collected in the St. Lawrence River Basin, New York, 2010.

[NWIS, National Water Information System; WY, water year, the 12-month period from October 1 through September 30 of the following year. The water year is designated by the calendar year in which it ends]

\begin{tabular}{|c|c|c|c|}
\hline \multirow{2}{*}{$\begin{array}{l}\text { U.S. Geological } \\
\text { Survey NWIS } \\
\text { parameter code }\end{array}$} & \multirow[b]{2}{*}{ Constituent } & \multicolumn{2}{|c|}{$\begin{array}{c}\text { Laboratory reporting } \\
\text { level }\end{array}$} \\
\hline & & WY10 & WY11 \\
\hline \multicolumn{4}{|c|}{ Trace Elements in unfiltered water, in micrograms per liter } \\
\hline 01059 & Thallium & 0.12 & 0.06 \\
\hline \multicolumn{4}{|c|}{ Pesticides in filtered water, in micrograms per liter } \\
\hline 82660 & 2,6-Diethylaniline & .006 & .006 \\
\hline 49260 & Acetochlor & .010 & .010 \\
\hline 46342 & Alachlor & .008 & .008 \\
\hline 34253 & alpha-HCH & .004 & .004 \\
\hline 82686 & Azinphos-methyl & .120 & .120 \\
\hline 04028 & Butylate & .004 & .004 \\
\hline 82680 & Carbaryl & .060 & .060 \\
\hline 82674 & Carbofuran & .060 & .060 \\
\hline 38933 & Chlorpyrifos & .010 & .004 \\
\hline 82687 & cis-Permethrin & .014 & .010 \\
\hline 04041 & Cyanazine & .022 & .022 \\
\hline 82682 & DCPA & .008 & .008 \\
\hline 62170 & Desulfinylfipronil & .012 & .012 \\
\hline 39572 & Diazinon & .005 & .006 \\
\hline 39381 & Dieldrin & .009 & .008 \\
\hline 82668 & EPTC & .002 & .006 \\
\hline 82663 & Ethalfluralin & .006 & .006 \\
\hline 82672 & Ethoprop & .016 & .016 \\
\hline 62169 & Desulfinylfipronil amide & .029 & .029 \\
\hline 62167 & Fipronil sulfide & .013 & .012 \\
\hline 62168 & Fipronil sulfone & .024 & .024 \\
\hline 62166 & Fipronil & .018 & .018 \\
\hline 04095 & Fonofos & .004 & .005 \\
\hline 39341 & Lindane & .004 & .004 \\
\hline 82666 & Linuron & .060 & .060 \\
\hline 39532 & Malathion & .016 & .016 \\
\hline 82667 & Methyl parathion & .008 & .008 \\
\hline 82630 & Metribuzin & .012 & .012 \\
\hline 82671 & Molinate & .003 & .004 \\
\hline 82684 & Napropamide & .008 & .008 \\
\hline 34653 & $p, p^{\prime}-\mathrm{DDE}$ & .002 & .002 \\
\hline 39542 & Parathion & .020 & .020 \\
\hline 82669 & Pebulate & .016 & .016 \\
\hline 82683 & Pendimethalin & .012 & .012 \\
\hline 82664 & Phorate & .020 & .020 \\
\hline 04037 & Prometon & .01 & .01 \\
\hline
\end{tabular}


Table 2-1. Constituents that were not detected in groundwater samples collected in the St. Lawrence River Basin, New York, 2010.-Continued

[NWIS, National Water Information System; WY, water year, the 12-month period from October 1 through September 30 of the following year. The water year is designated by the calendar year in which it ends]

\begin{tabular}{|c|c|c|c|}
\hline \multirow{2}{*}{$\begin{array}{l}\text { U.S. Geological } \\
\text { Survey NWIS } \\
\text { parameter code }\end{array}$} & \multirow[b]{2}{*}{ Constituent } & \multicolumn{2}{|c|}{$\begin{array}{c}\text { Laboratory reporting } \\
\text { level }\end{array}$} \\
\hline & & WY10 & WY11 \\
\hline \multicolumn{4}{|c|}{ Pesticides in filtered water, in micrograms per liter--continued } \\
\hline 82676 & Propyzamide & .004 & .004 \\
\hline 04024 & Propachlor & .006 & .006 \\
\hline 82679 & Propanil & .010 & .010 \\
\hline 82685 & Propargite & .02 & .02 \\
\hline 82670 & Tebuthiuron & .03 & .03 \\
\hline 82675 & Terbufos & .02 & .02 \\
\hline 82681 & Thiobencarb & .016 & .016 \\
\hline 82678 & Triallate & .006 & .005 \\
\hline 82661 & Trifluralin & .018 & .018 \\
\hline \multicolumn{4}{|c|}{ Volatile organic compounds in unfiltered water, in micrograms per liter } \\
\hline 34506 & 1,1,1-Trichloroethane & .1 & .1 \\
\hline 77652 & 1,1,2-Trichloro-1,2,2-trifluoroethane & .1 & .1 \\
\hline 34496 & 1,1-Dichloroethane & .1 & .1 \\
\hline 34501 & 1,1-Dichloroethene & .1 & .1 \\
\hline 34536 & 1,2-Dichlorobenzene & .1 & .1 \\
\hline 32103 & 1,2-Dichloroethane & .2 & .2 \\
\hline 34541 & 1,2-Dichloropropane & .1 & .1 \\
\hline 34566 & 1,3-Dichlorobenzene & .1 & .1 \\
\hline 34571 & 1,4-Dichlorobenzene & .1 & .1 \\
\hline 34030 & Benzene & .1 & .1 \\
\hline 32101 & Bromodichloromethane & .1 & .1 \\
\hline 32104 & Tribromomethane & .2 & .2 \\
\hline 34301 & Chlorobenzene & .1 & .1 \\
\hline 77093 & cis-1,2-Dichloroethene & .1 & .1 \\
\hline 32105 & Dibromochloromethane & .2 & .2 \\
\hline 34668 & Dichlorodifluoromethane & .2 & .2 \\
\hline 34423 & Dichloromethane & .2 & .2 \\
\hline 81576 & Diethyl ether & .2 & .2 \\
\hline 81577 & Diisopropyl ether & .2 & .2 \\
\hline 34371 & Ethylbenzene & .1 & .1 \\
\hline 50005 & Methyl tert-pentyl ether & .2 & .2 \\
\hline 85795 & $m$-Xylene plus $p$-xylene & .2 & .2 \\
\hline 77135 & $o$-Xylene & .1 & .1 \\
\hline 77128 & Styrene & .1 & .1 \\
\hline 50004 & tert-Butyl ethyl ether & .1 & .1 \\
\hline 78032 & Methyl tert-butyl ether & .2 & .2 \\
\hline 32102 & Tetrachloromethane & .2 & .2 \\
\hline 34546 & trans-1,2-Dichloroethene & .1 & .1 \\
\hline 39180 & Trichloroethene & .1 & .1 \\
\hline 34488 & Trichlorofluoromethane & .2 & .2 \\
\hline 39175 & Vinyl chloride & .2 & .2 \\
\hline
\end{tabular}


Table 2-2. Physiochemical properties of groundwater samples collected in the St. Lawrence River Basin, New York, 2010.

[mg/L, milligrams per liter; $\mu \mathrm{S} / \mathrm{cm} @ 25^{\circ} \mathrm{C}$, microsiemens per centimeter at 25 degrees Celsius; (00080), U.S. Geological Survey National Water Information System parameter code; <, less than; --, not analyzed. Bold values exceed one or more drinking-water standards. Well locations are shown in figures 3 and 4$]$

\begin{tabular}{|c|c|c|c|c|c|}
\hline $\begin{array}{c}\text { Well } \\
\text { number }^{1}\end{array}$ & $\begin{array}{l}\text { Color, } \\
\text { platinum- } \\
\text { cobalt units } \\
(00080)\end{array}$ & $\begin{array}{c}\text { Carbon } \\
\text { dioxide, } \\
\text { mg/L } \\
(00405)\end{array}$ & $\begin{array}{c}\text { Dissolved } \\
\text { oxygen, } \\
\text { mg/L } \\
(00300)\end{array}$ & $\begin{array}{c}\mathrm{pH}, \\
\text { field, } \\
\text { standard units } \\
(00400)\end{array}$ & $\begin{array}{c}\text { Specific } \\
\text { conductance, } \\
\text { field, } \\
\mu \mathrm{S} / \mathrm{cm} @ 25^{\circ} \mathrm{C} \\
(00095)\end{array}$ \\
\hline \multicolumn{6}{|c|}{ Sand and gravel wells } \\
\hline F543 & 2 & 19.7 & 6.3 & 6.5 & 96 \\
\hline F573 & $<1$ & 2.7 & 7.4 & 8.2 & 208 \\
\hline J1736 & $<1$ & 30.4 & .2 & 7.2 & 1,280 \\
\hline ST378 & $<1$ & 2.8 & 3.0 & 8.2 & 197 \\
\hline ST2584 & $<1$ & 9.8 & 5.7 & 7.2 & 208 \\
\hline \multicolumn{6}{|c|}{ Bedrock wells } \\
\hline CL674 & $<1$ & 7.0 & 7.5 & 7.5 & 318 \\
\hline F91 & $<1$ & 7.3 & 8.4 & 7.6 & 337 \\
\hline F1042 & $<1$ & 1.9 & 9.7 & 8.4 & 80 \\
\hline F1051 & 2 & .5 & .1 & 8.4 & 131 \\
\hline H80 & 2 & 1.1 & 6.0 & 8.3 & 146 \\
\hline J836 & 10 & 49.2 & 1.6 & 6.7 & 438 \\
\hline ST950 & $<1$ & 12.8 & 4.5 & 7.6 & 600 \\
\hline ST1424 & $<1$ & 9.9 & $<.3$ & 7.6 & 562 \\
\hline ST1426 & 2 & 13.0 & $<.05$ & 7.5 & 655 \\
\hline ST2074 & 5 & 13.9 & .2 & 7.2 & 393 \\
\hline ST2291 & $<1$ & 2.4 & 8.3 & 8.5 & 75 \\
\hline ST2758 & $<1$ & 2.6 & $<.05$ & 8.0 & 363 \\
\hline ST3032 & 5 & -- & .1 & 7.4 & 573 \\
\hline ST3204 & $<1$ & 39.3 & .1 & 7.2 & 669 \\
\hline ST3322 & 35 & 1.1 & 1.0 & 8.1 & 98 \\
\hline
\end{tabular}

${ }^{1}$ CL, Clinton County; F, Franklin County; H, Hamilton County; J, Jefferson County; ST, St. Lawrence County. 
Table 2-2. Physiochemical properties of groundwater samples collected in the St. Lawrence River Basin, New York, 2010. - Continued

[mg/L, milligrams per liter; $\mu \mathrm{S} / \mathrm{cm} @ 25^{\circ} \mathrm{C}$, microsiemens per centimeter at 25 degrees Celsius; (00080), U.S. Geological Survey National Water Information System parameter code; <, less than; --, not analyzed; E, estimated concentration. Bold values exceed one or more drinking-water standards. Well locations are shown in figures 3 and 4]

\begin{tabular}{|c|c|c|c|c|c|}
\hline $\begin{array}{c}\text { Well } \\
\text { number }{ }^{1}\end{array}$ & $\begin{array}{c}\text { Water } \\
\text { temperature, } \\
\text { field, } \\
\text { degrees } \\
\text { Celsius } \\
(00010) \\
\end{array}$ & $\begin{array}{c}\text { Argon, } \\
\text { unfiltered, } \\
\text { mg/L } \\
(82043)\end{array}$ & $\begin{array}{c}\text { Dissolved } \\
\text { nitrogen gas, } \\
\text { unfiltered, } \\
\mathrm{mg} / \mathrm{L} \\
(00597) \\
\end{array}$ & $\begin{array}{c}\text { Hydrogen } \\
\text { sulfide odor } \\
\text { field, } \\
(71875) \\
\end{array}$ & $\begin{array}{c}\text { Methane, } \\
\text { unfiltered } \\
\mathrm{mg} / \mathrm{L} \\
(76994)\end{array}$ \\
\hline \multicolumn{6}{|c|}{ Sand and gravel wells } \\
\hline F543 & 11.0 & 0.7635 & 20.56 & Absent & $<0.0005$ \\
\hline F573 & 7.3 & .7173 & 18.93 & Absent & $<.0005$ \\
\hline J1736 & 10.4 & .7738 & 23.84 & Absent & .212 \\
\hline ST378 & 9.0 & .7234 & 19.58 & Absent & $<.0005$ \\
\hline ST2584 & 10.0 & .7389 & 20.02 & Absent & E.0005 \\
\hline \multicolumn{6}{|c|}{ Bedrock wells } \\
\hline CL674 & 9.9 & .8380 & 25.32 & Present & .0031 \\
\hline F91 & 13.8 & .7341 & 19.48 & Absent & $<.0005$ \\
\hline F1042 & 9.0 & .7851 & 21.59 & Absent & $<.0005$ \\
\hline F1051 & 10.0 & .7183 & 19.33 & Absent & .0007 \\
\hline H80 & 8.6 & .8795 & 26.28 & Absent & .0015 \\
\hline J836 & 13.1 & .7958 & 22.32 & Absent & $<.0005$ \\
\hline ST950 & 9.3 & .9029 & 27.76 & Present & $<.0005$ \\
\hline ST1424 & 10.1 & .9129 & 27.76 & Absent & $<.0005$ \\
\hline ST1426 & 8.6 & .8360 & 24.85 & Absent & .0045 \\
\hline ST2074 & 10.7 & .8425 & 24.79 & Absent & .0011 \\
\hline ST2291 & 12.4 & .8039 & 22.46 & Absent & $<.0005$ \\
\hline ST2758 & 10.6 & .8444 & 24.74 & Present & .873 \\
\hline ST3032 & 10.8 & -- & -- & Absent & -- \\
\hline ST3204 & 13.0 & .8410 & 24.84 & Absent & 1.49 \\
\hline ST3322 & 8.9 & .7561 & 20.44 & Absent & $<.0005$ \\
\hline
\end{tabular}

${ }^{1}$ CL, Clinton County; F, Franklin County; H, Hamilton County; J, Jefferson County; ST, St. Lawrence County. 
Table 2-3. Concentrations of major ions in groundwater samples collected in the St. Lawrence River Basin, New York, 2010.

[mg/L, milligrams per liter; $\mathrm{CaCO}_{3}$, calcium carbonate; (00900), U.S. Geological Survey National Water Information System parameter code; E, estimated concentration; ${ }^{\circ}$ Celsius, degrees Celsius. Bold values exceed one or more drinking-water standards. Well locations are shown in figures 3 and 4$]$

\begin{tabular}{|c|c|c|c|c|c|c|c|}
\hline $\begin{array}{c}\text { Well } \\
\text { number }{ }^{1}\end{array}$ & $\begin{array}{l}\text { Hardness, } \\
\text { filtered, } \\
\text { mg/L as } \\
\mathrm{CaCO}_{3} \\
(00900) \\
\end{array}$ & $\begin{array}{l}\text { Calcium, } \\
\text { filtered, } \\
\text { mg/L } \\
(00915)\end{array}$ & $\begin{array}{c}\text { Magnesium, } \\
\text { filtered, } \\
\text { mg/L } \\
(00925) \\
\end{array}$ & $\begin{array}{c}\text { Potassium, } \\
\text { filtered, } \\
\text { mg/L } \\
(00935)\end{array}$ & $\begin{array}{c}\text { Sodium, } \\
\text { filtered, } \\
\text { mg/L } \\
(00930)\end{array}$ & $\begin{array}{l}\text { Acid neutralizing } \\
\text { capacity, } \\
\text { unfiltered, } \\
\text { mg/L as } \mathrm{CaCO}_{3} \\
(90410)\end{array}$ & $\begin{array}{c}\text { Alkalinity, } \\
\text { filtered, } \\
\text { fixed endpoint, } \\
\text { laboratory, } \\
\text { mg/L as } \mathrm{CaCO}_{3} \\
(29801)\end{array}$ \\
\hline \multicolumn{8}{|c|}{ Sand and gravel wells } \\
\hline F543 & 35.8 & 9.03 & 3.21 & 0.69 & 3.24 & 32 & 32 \\
\hline F573 & 101 & 27.7 & 7.77 & .72 & 3.53 & 98 & 94 \\
\hline J1736 & 419 & 108 & 36.2 & 4.08 & 105 & 295 & 294 \\
\hline ST378 & 91.8 & 23.2 & 8.22 & .86 & 2.76 & 89 & 89 \\
\hline ST2584 & 80.9 & 22.9 & 5.77 & 1.68 & 8.95 & 61 & 62 \\
\hline \multicolumn{8}{|c|}{ Bedrock wells } \\
\hline CL674 & 158 & 41.4 & 13.2 & 1.45 & 3.85 & 146 & 143 \\
\hline F91 & 165 & 45.7 & 12.3 & 1.20 & 4.14 & 136 & 138 \\
\hline F1042 & 32.4 & 10.2 & 1.69 & .43 & 3.04 & 31 & 31 \\
\hline F1051 & 53.2 & 18.4 & 1.78 & .45 & 7.93 & 67 & 67 \\
\hline H80 & 60.4 & 20.6 & 2.19 & .75 & 7.28 & 57 & 58 \\
\hline J836 & 169 & 50.8 & 10.2 & 2.94 & 20.8 & 145 & 144 \\
\hline ST950 & 254 & 53.4 & 29.2 & 4.03 & 29.5 & 240 & 239 \\
\hline ST1424 & 220 & 49.2 & 23.7 & 3.60 & 32.2 & 200 & 205 \\
\hline ST1426 & 299 & 68.4 & 31.1 & 2.33 & 21.2 & 223 & 218 \\
\hline ST2074 & 172 & 47.8 & 12.8 & 1.68 & 13.9 & 141 & 141 \\
\hline ST2291 & 29.0 & 8.37 & 1.97 & .83 & 2.86 & 31 & 31 \\
\hline ST2758 & 132 & 27.7 & 15.3 & 4.50 & 25.0 & 155 & 155 \\
\hline ST3032 & 223 & 54.8 & 21.0 & 13.8 & 25.0 & 248 & 245 \\
\hline ST3204 & 344 & 75.2 & 37.9 & 1.39 & 12.4 & 342 & 333 \\
\hline ST3322 & 43.7 & 11.2 & 3.85 & .54 & 2.21 & 46 & 45 \\
\hline
\end{tabular}

${ }^{1}$ CL, Clinton County; F, Franklin County; H, Hamilton County; J, Jefferson County; ST, St. Lawrence County.

${ }^{2}$ Bicarbonate values calculated from alkalinity. 
Table 2-3. Concentrations of major ions in groundwater samples collected in the St. Lawrence River Basin, New York, 2010.-Continued

[mg/L, milligrams per liter; $\mathrm{CaCO}_{3}$, calcium carbonate; (29805), U.S. Geological Survey National Water Information System parameter code; E, estimated concentration; ${ }^{\circ}$ Celsius, degrees Celsius. Bold values exceed one or more drinking-water standards. Well locations are shown in figures 3 and 4$]$

\begin{tabular}{|c|c|c|c|c|c|c|}
\hline $\begin{array}{c}\text { Well } \\
\text { number }{ }^{1}\end{array}$ & $\begin{array}{l}\text { Bicarbonate }^{2} \text {, } \\
\text { filtered, } \\
\text { fixed } \\
\text { endpoint, } \\
\text { laboratory, } \\
\text { mg/L } \\
(29805)\end{array}$ & $\begin{array}{c}\text { Chloride, } \\
\text { filtered, } \\
\text { mg/L } \\
(00940)\end{array}$ & $\begin{array}{c}\text { Fluoride, } \\
\text { filtered, } \\
\text { mg/L } \\
(00950)\end{array}$ & $\begin{array}{c}\text { Silica, } \\
\text { filtered, } \\
\text { mg/L } \\
(00955)\end{array}$ & $\begin{array}{c}\text { Sulfate, } \\
\text { filtered, } \\
\text { mg/L } \\
(00945)\end{array}$ & $\begin{array}{c}\text { Dissolved } \\
\text { solids, } \\
\text { dried at } 180^{\circ} \mathrm{C} \text {, } \\
\text { filtered, } \\
\mathrm{mg} / \mathrm{L} \\
(70300)\end{array}$ \\
\hline \multicolumn{7}{|c|}{ Sand and gravel wells } \\
\hline F543 & 39 & 3.72 & E0.06 & 14.9 & 7.48 & 69 \\
\hline F573 & 115 & 6.24 & .08 & 9.62 & 9.96 & 120 \\
\hline J1736 & 359 & 206 & .57 & 12.3 & 78.5 & 756 \\
\hline ST378 & 109 & 4.37 & E.06 & 9.70 & 9.56 & 117 \\
\hline ST2584 & 76 & 19.6 & .43 & 12.8 & 8.52 & 126 \\
\hline \multicolumn{7}{|c|}{ Bedrock wells } \\
\hline CL674 & 174 & 3.98 & .12 & 10.1 & 23.0 & 191 \\
\hline F91 & 168 & 7.01 & .06 & 12.3 & 16.9 & 201 \\
\hline F1042 & 38 & .39 & .36 & 16.2 & 6.80 & 55 \\
\hline F1051 & 82 & 1.00 & .28 & 12.2 & 2.89 & 89 \\
\hline H80 & 71 & 1.30 & .95 & 10.8 & 16.4 & 99 \\
\hline J836 & 176 & 31.2 & .13 & 9.77 & 34.2 & 251 \\
\hline ST950 & 292 & 31.9 & .51 & 11.9 & 46.7 & 352 \\
\hline ST1424 & 250 & 31.2 & .34 & 7.85 & 49.5 & 304 \\
\hline ST1426 & 266 & 58.4 & .28 & 10.5 & 37.8 & 372 \\
\hline ST2074 & 172 & 13.6 & .70 & 14.6 & 40.5 & 242 \\
\hline ST2291 & 38 & 1.53 & .14 & 18.9 & 5.78 & 59 \\
\hline ST2758 & 189 & 17.8 & .78 & 10.0 & 14.4 & 218 \\
\hline ST3032 & 299 & 23.1 & .09 & 6.26 & 23.9 & 320 \\
\hline ST3204 & 406 & 2.68 & .17 & 15.6 & 38.4 & 384 \\
\hline ST3322 & 55 & .36 & .32 & 11.3 & 5.09 & 60 \\
\hline
\end{tabular}

\footnotetext{
${ }^{1}$ CL, Clinton County; F, Franklin County; H, Hamilton County; J, Jefferson County; ST, St. Lawrence County.
}

${ }^{2}$ Bicarbonate values calculated from alkalinity 
Table 2-4. Concentrations of nutrients and organic carbon in groundwater samples collected in the St. Lawrence

River Basin, New York, 2010.

[N, nitrogen; P, phosphorus; mg/L, milligrams per liter; (00623), U.S. Geological Survey National Water Information System parameter code; < less than; E, estimated concentration. Well locations are shown in figures 3 and 4]

\begin{tabular}{|c|c|c|c|c|c|c|}
\hline $\begin{array}{c}\text { Well } \\
\text { number }\end{array}$ & $\begin{array}{c}\text { Ammonia } \\
\text { plus organic- } \\
\mathrm{N}, \\
\text { filtered, } \\
\text { mg/L as N } \\
(00623)\end{array}$ & $\begin{array}{l}\text { Ammonia, } \\
\text { filtered, } \\
\text { mg/L as N } \\
(00608)\end{array}$ & $\begin{array}{l}\text { Nitrate plus } \\
\text { nitrite, } \\
\text { filtered, } \\
\text { mg/L as N } \\
\text { (00631) }\end{array}$ & $\begin{array}{l}\text { Nitrite, } \\
\text { filtered, } \\
\text { mg/L as N } \\
(00613)\end{array}$ & $\begin{array}{c}\text { Ortho- } \\
\text { phosphate, } \\
\text { filtered, } \\
\text { mg/L as P } \\
\text { (00671) }\end{array}$ & $\begin{array}{c}\text { Organic } \\
\text { carbon, } \\
\text { unfiltered, } \\
\text { mg/L } \\
(00680)\end{array}$ \\
\hline \multicolumn{7}{|c|}{ Sand and gravel wells } \\
\hline F543 & $<0.10$ & $<0.020$ & 0.92 & $<0.002$ & 0.011 & E0.6 \\
\hline F573 & $<.05$ & $<.010$ & .23 & $<.001$ & .015 & $<.3$ \\
\hline J1736 & E.06 & .026 & $<.04$ & E.001 & .008 & .7 \\
\hline ST378 & $<.10$ & $<.020$ & .09 & $<.002$ & .009 & E.3 \\
\hline ST2584 & E.06 & $<.020$ & .63 & $<.002$ & E.008 & E.4 \\
\hline \multicolumn{7}{|c|}{ Bedrock wells } \\
\hline CL674 & $<.05$ & .017 & $<.02$ & $<.001$ & .027 & .6 \\
\hline F91 & .06 & $<.010$ & 3.91 & $<.001$ & .019 & .6 \\
\hline F1042 & $<.10$ & $<.020$ & .48 & $<.002$ & .035 & E.3 \\
\hline F1051 & $<.10$ & $<.020$ & E.03 & $<.002$ & .089 & .8 \\
\hline H80 & $<.10$ & $<.020$ & .10 & .003 & .011 & E.4 \\
\hline J836 & .11 & .023 & .09 & $<.002$ & E.008 & 2.1 \\
\hline ST950 & .21 & .130 & $<.04$ & $<.002$ & .016 & .9 \\
\hline ST1424 & .14 & .117 & $<.02$ & $<.001$ & .007 & .7 \\
\hline ST1426 & E.10 & .074 & $<.04$ & $<.002$ & .008 & E.6 \\
\hline ST2074 & .13 & E.020 & .47 & .005 & .015 & 1.6 \\
\hline ST2291 & $<.10$ & $<.020$ & .06 & $<.002$ & .022 & $<.6$ \\
\hline ST2758 & .18 & .136 & $<.04$ & $<.002$ & .024 & 1.4 \\
\hline ST3032 & .63 & .350 & .20 & .011 & E.006 & 2.2 \\
\hline ST3204 & .12 & .046 & $<.04$ & $<.002$ & .013 & 1.2 \\
\hline ST3322 & E.05 & $<.020$ & .28 & E.002 & E.008 & E.3 \\
\hline
\end{tabular}

${ }^{1}$ CL, Clinton County; F, Franklin County; H, Hamilton County; J, Jefferson County; ST, St. Lawrence County. 
Table 2-5. Concentrations of trace elements in groundwater samples collected in the St. Lawrence River Basin, New York, 2010.

[ $\mu \mathrm{g} / \mathrm{L}$, micrograms per liter; (01105), U.S. Geological Survey National Water Information System parameter code; <, less than; E, estimated concentration. Bold values exceed one or more drinking-water standards. Well locations are shown in figures 3 and 4]

\begin{tabular}{|c|c|c|c|c|c|c|c|c|}
\hline $\begin{array}{c}\text { Well } \\
\text { number }^{1}\end{array}$ & $\begin{array}{c}\text { Aluminum, } \\
\text { unfiltered, } \\
\mu \mathrm{g} / \mathrm{L} \\
(01105)\end{array}$ & $\begin{array}{c}\text { Antimony, } \\
\text { unfiltered, } \\
\mu \mathrm{g} / \mathrm{L} \\
(01097) \\
\end{array}$ & $\begin{array}{c}\text { Arsenic, } \\
\text { unfiltered, } \\
\mu \mathrm{g} / \mathrm{L} \\
(01002)\end{array}$ & $\begin{array}{l}\text { Barium, } \\
\text { unfiltered, } \\
\mu \mathrm{g} / \mathrm{L} \\
(01007)\end{array}$ & $\begin{array}{c}\text { Beryllium, } \\
\text { unfiltered, } \\
\mu \mathrm{g} / \mathrm{L} \\
(01012)\end{array}$ & $\begin{array}{c}\text { Boron, } \\
\text { filtered, } \\
\mu \mathrm{g} / \mathrm{L} \\
(01020)\end{array}$ & $\begin{array}{c}\text { Cadmium, } \\
\text { unfiltered, } \\
\mu g / L \\
(01027) \\
\end{array}$ & $\begin{array}{c}\text { Chromium, } \\
\text { unfiltered, } \\
\mu \mathrm{g} / \mathrm{L} \\
(01034)\end{array}$ \\
\hline \multicolumn{9}{|c|}{ Sand and gravel wells } \\
\hline F543 & $<6$ & $<0.4$ & $<0.18$ & 8.3 & $<0.04$ & 7.6 & $<0.04$ & $<0.42$ \\
\hline F573 & $<3$ & $<.2$ & 1.1 & 19.5 & $<.02$ & 3.4 & $<.05$ & .58 \\
\hline ST378 & $<6$ & $<.4$ & .46 & 52.3 & $<.04$ & 7.1 & $<.04$ & E.23 \\
\hline ST2584 & $<6$ & $<.4$ & .32 & 12.8 & $<.04$ & 12 & $<.04$ & E.27 \\
\hline \multicolumn{9}{|c|}{ Bedrock wells } \\
\hline CL674 & $<3$ & $<.2$ & 1.3 & 53.8 & $<.02$ & 8.9 & $<.05$ & $<.21$ \\
\hline F91 & $<3$ & $<.2$ & 1.3 & 18.1 & $<.02$ & 10 & $<.05$ & .69 \\
\hline J836 & 19 & $<.4$ & 1.0 & 70.1 & $<.04$ & 50 & $<.04$ & E.21 \\
\hline ST950 & $<6$ & $<.4$ & .75 & 108 & $<.04$ & 162 & $<.04$ & $<.42$ \\
\hline ST1424 & $<3$ & $<.2$ & 1.5 & 41.6 & $<.02$ & 168 & $<.05$ & $<.21$ \\
\hline ST1426 & $<6$ & $<.4$ & 2.2 & 119 & $<.04$ & 54 & $<.04$ & $<.42$ \\
\hline ST2074 & 1,310 & $<.4$ & .78 & 217 & .13 & 174 & $<.04$ & 2.6 \\
\hline ST2291 & E5 & $<.4$ & .23 & 1.1 & $<.04$ & 3.6 & $<.04$ & 1.0 \\
\hline ST2758 & $<6$ & $<.4$ & .41 & 329 & $<.04$ & 164 & $<.04$ & $<.42$ \\
\hline ST3032 & 11 & E.4 & .93 & 168 & $<.04$ & 50 & E.04 & 2.5 \\
\hline ST3204 & $<6$ & $<.4$ & 2.3 & 121 & $<.04$ & 20 & $<.04$ & $<.42$ \\
\hline ST3322 & 14 & $<.4$ & .24 & 1.0 & $<.04$ & 4.7 & $<.04$ & E.21 \\
\hline
\end{tabular}

${ }^{1}$ CL, Clinton County; F, Franklin County; H, Hamilton County; J, Jefferson County; ST, St. Lawrence County. 
Table 2-5. Concentrations of trace elements in groundwater samples collected in the St. Lawrence River Basin, New York, 2010.-Continued

[ $\mu \mathrm{g} / \mathrm{L}$, micrograms per liter; (01105), U.S. Geological Survey National Water Information System parameter code; <, less than; E, estimated concentration. Bold values exceed one or more drinking-water standards. Well locations are shown in figures 3 and 4]

\begin{tabular}{|c|c|c|c|c|c|c|c|c|}
\hline $\begin{array}{c}\text { Well } \\
\text { number }{ }^{1}\end{array}$ & $\begin{array}{c}\text { Cobalt, } \\
\text { unfiltered, } \\
\mu \mathrm{g} / \mathrm{L} \\
(01037) \\
\end{array}$ & $\begin{array}{c}\text { Copper, } \\
\text { unfiltered, } \\
\mu \mathrm{g} / \mathrm{L} \\
(01042)\end{array}$ & $\begin{array}{c}\text { Iron, } \\
\text { filtered, } \\
\mu \mathrm{g} / \mathrm{L} \\
(01046)\end{array}$ & $\begin{array}{c}\text { Iron, } \\
\text { unfiltered, } \\
\mu \mathrm{g} / \mathrm{L} \\
(01045)\end{array}$ & $\begin{array}{c}\text { Lead, } \\
\text { unfiltered, } \\
\mu \mathrm{g} / \mathrm{L} \\
(01051)\end{array}$ & $\begin{array}{c}\text { Lithium, } \\
\text { unfiltered, } \\
\mu \mathrm{g} / \mathrm{L} \\
(01132)\end{array}$ & $\begin{array}{c}\text { Manganese, } \\
\text { filtered, } \\
\mu \mathrm{g} / \mathrm{L} \\
(01056) \\
\end{array}$ & $\begin{array}{c}\text { Manganese, } \\
\text { unfiltered, } \\
\mu \mathrm{g} / \mathrm{L} \\
(01055) \\
\end{array}$ \\
\hline \multicolumn{9}{|c|}{ Sand and gravel wells } \\
\hline F543 & $<0.04$ & 195 & 8 & 56 & 0.48 & 1.0 & 1.9 & 3.0 \\
\hline F573 & $<.02$ & 2.4 & $<3$ & $<5$ & $<.04$ & 1.3 & .3 & $<.4$ \\
\hline ST378 & $<.04$ & 2.2 & $<6$ & $<9$ & .16 & .5 & $<.2$ & $<.8$ \\
\hline ST2584 & $<.04$ & 48.9 & E5 & 106 & .49 & 2.4 & 1.9 & 3.1 \\
\hline \multicolumn{9}{|c|}{ Bedrock wells } \\
\hline CL674 & .08 & 1.3 & 96 & 127 & .04 & 2.2 & 136 & 142 \\
\hline F91 & .03 & 24.3 & $<3$ & $<5$ & .12 & 1.1 & .2 & $<.4$ \\
\hline J836 & .81 & 7.4 & 491 & 2,150 & .64 & 6.8 & 29.6 & 33.7 \\
\hline ST950 & $<.04$ & 2.2 & 36 & 45 & .99 & 23.1 & 8.0 & 8.5 \\
\hline ST1424 & $<.02$ & $<.70$ & 195 & 334 & $<.04$ & 20.5 & 29.3 & 32.6 \\
\hline ST1426 & .68 & $<1.4$ & 127 & 274 & .33 & 8.3 & 112 & 117 \\
\hline ST2074 & .74 & 11.9 & 51 & 2,500 & 1.03 & 11.9 & 40.2 & 115 \\
\hline ST2291 & $<.04$ & 1.9 & 74 & 326 & .16 & 1.2 & 1.4 & 5.9 \\
\hline ST2758 & $<.04$ & $<1.4$ & 10 & 15 & E.05 & 25.7 & 4.5 & 4.8 \\
\hline ST3032 & .41 & 3.1 & E4 & 3,910 & .46 & 5.2 & 272 & 308 \\
\hline ST3204 & .28 & $<1.4$ & 421 & 434 & .24 & 6.0 & 24.4 & 26.9 \\
\hline ST3322 & .13 & $<1.4$ & 396 & 2,260 & 1.50 & 3.4 & 6.8 & 15.7 \\
\hline
\end{tabular}

${ }^{1}$ CL, Clinton County; F, Franklin County; H, Hamilton County; J, Jefferson County; ST, St. Lawrence County. 
Table 2-5. Concentrations of trace elements in groundwater samples collected in the St. Lawrence River Basin, New York, 2010.-Continued

[ $\mu \mathrm{g} / \mathrm{L}$, micrograms per liter; (01105), U.S. Geological Survey National Water Information System parameter code; <, less than; E, estimated concentration. Bold values exceed one or more drinking-water standards. Well locations are shown in figures 3 and 4]

\begin{tabular}{|c|c|c|c|c|c|c|c|c|}
\hline $\begin{array}{c}\text { Well } \\
\text { number }^{1}\end{array}$ & $\begin{array}{c}\text { Mercury, } \\
\text { unfiltered, } \\
\mu \mathrm{g} / \mathrm{L} \\
(71900)\end{array}$ & $\begin{array}{c}\text { Molybdenum, } \\
\text { unfiltered, } \\
\mu \mathrm{g} / \mathrm{L} \\
(01062)\end{array}$ & $\begin{array}{c}\text { Nickel, } \\
\text { unfiltered, } \\
\mu \mathrm{g} / \mathrm{L} \\
(01067)\end{array}$ & $\begin{array}{c}\text { Selenium, } \\
\text { unfiltered, } \\
\mu \mathrm{g} / \mathrm{L} \\
(01147)\end{array}$ & $\begin{array}{c}\text { Silver, } \\
\text { unfiltered, } \\
\mu \mathrm{g} / \mathrm{L} \\
(01077)\end{array}$ & $\begin{array}{c}\text { Strontium, } \\
\text { unfiltered, } \\
\mu \mathrm{g} / \mathrm{L} \\
(01082)\end{array}$ & $\begin{array}{c}\text { Zinc, } \\
\text { unfiltered, } \\
\mu \mathrm{g} / \mathrm{L} \\
(01092)\end{array}$ & $\begin{array}{c}\text { Uranium, } \\
\text { unfiltered, } \\
\mu \mathrm{g} / \mathrm{L} \\
(28011)\end{array}$ \\
\hline \multicolumn{9}{|c|}{ Sand and gravel wells } \\
\hline F543 & $<0.010$ & 0.1 & E0.21 & $<0.10$ & E0.01 & 30.2 & E1.9 & 0.047 \\
\hline F573 & $<.005$ & .7 & $<.12$ & .10 & $<.01$ & 76.3 & $<2.4$ & .374 \\
\hline J1736 & $<.010$ & .7 & 1.0 & E.05 & $<.02$ & 6,360 & 3.6 & .726 \\
\hline ST378 & $<.010$ & .5 & $<.36$ & E.08 & $<.02$ & 40.3 & 3.0 & .325 \\
\hline ST2584 & $<.010$ & .7 & $<.36$ & $<.10$ & $<.02$ & 62.7 & 10.1 & .308 \\
\hline \multicolumn{9}{|c|}{ Bedrock wells } \\
\hline CL674 & $<.005$ & 2.8 & $<.12$ & $<.05$ & $<.01$ & 214 & 3.1 & .410 \\
\hline F91 & $<.005$ & .2 & $<.12$ & .06 & $<.01$ & 205 & 23.1 & .302 \\
\hline F1042 & $<.010$ & 2.6 & $<.36$ & $<.10$ & $<.02$ & 30.9 & E1.3 & .452 \\
\hline F1051 & $<.010$ & 3.4 & $<.36$ & $<.10$ & $<.02$ & 59.8 & 3.8 & .946 \\
\hline H80 & $<.010$ & 5.2 & $<.36$ & .25 & $<.02$ & 202 & 7.6 & 1.07 \\
\hline J836 & $<.010$ & .2 & 2.0 & E.06 & $<.02$ & 285 & 7.0 & .333 \\
\hline ST950 & $<.010$ & .9 & $<.36$ & $<.10$ & $<.02$ & 2,360 & 3.2 & .097 \\
\hline ST1424 & $<.005$ & 4.7 & $<.12$ & $<.05$ & $<.01$ & 2,030 & $<2.4$ & .400 \\
\hline ST1426 & $<.010$ & 4.0 & 1.2 & $<.10$ & $<.02$ & 1,010 & $<2.0$ & 1.62 \\
\hline ST2074 & E.010 & 1.2 & 1.9 & E.08 & E.01 & 2,820 & 8.7 & 4.25 \\
\hline ST2291 & $<.010$ & .4 & $<.36$ & $<.10$ & $<.02$ & 26.9 & E1.1 & .109 \\
\hline ST2758 & $<.010$ & .8 & $<.36$ & .25 & $<.02$ & 948 & E1.0 & .050 \\
\hline ST3032 & ${ }^{2}<.010$ & 1.2 & 3.0 & $<.10$ & $<.02$ & 1,160 & 7.1 & 1.86 \\
\hline ST3204 & $<.010$ & 4.3 & .76 & $<.10$ & $<.02$ & 1,280 & E1.3 & .468 \\
\hline ST3322 & $<.010$ & 1.8 & .39 & $<.10$ & $<.02$ & 26.8 & 3.0 & .159 \\
\hline
\end{tabular}

${ }^{1}$ CL, Clinton County; F, Franklin County; H, Hamilton County; J, Jefferson County; ST, St. Lawrence County.

${ }^{2}$ Mercury in ST3032 in filtered water, parameter code 71890 
Table 2-6. Concentrations of pesticides detected in groundwater samples collected in the St. Lawrence River Basin, New York, 2010.

[ $\mu \mathrm{g} / \mathrm{L}$, micrograms per liter; CIAT, 2-chloro-4-isopropylamino-6-amino-s-triazine; (04040), U.S. Geological Survey National Water Information System parameter code; <, less than; E, estimated concentration; M, presence verified but not quantified. Well locations are shown in figures 3 and 4]

\begin{tabular}{|c|c|c|c|c|c|c|c|}
\hline $\begin{array}{c}\text { Well } \\
\text { number }^{1}\end{array}$ & $\begin{array}{c}\text { CIAT, } \\
\text { filtered, } \\
\mu g / L \\
(04040)\end{array}$ & $\begin{array}{c}\text { Atrazine, } \\
\text { filtered, } \\
\mu \mathrm{g} / \mathrm{L} \\
(39632)\end{array}$ & $\begin{array}{c}\text { Benfluralin, } \\
\text { filtered, } \\
\mu \mathrm{g} / \mathrm{L} \\
(82673) \\
\end{array}$ & $\begin{array}{c}\text { Disulfoton, } \\
\text { filtered, } \\
\mu \mathrm{g} / \mathrm{L} \\
(82677)\end{array}$ & $\begin{array}{c}\text { Metolachlor, } \\
\text { filtered, } \\
\mu \mathrm{g} / \mathrm{L} \\
(39415)\end{array}$ & $\begin{array}{c}\text { Simazine, } \\
\text { filtered, } \\
\mu \mathrm{g} / \mathrm{L} \\
(04035) \\
\end{array}$ & $\begin{array}{c}\text { Terbacil, } \\
\text { filtered, } \\
\mu \mathrm{g} / \mathrm{L} \\
\text { (82665) }\end{array}$ \\
\hline \multicolumn{8}{|c|}{ Sand and gravel wells } \\
\hline F543 & $<0.014$ & $<0.007$ & $<0.014$ & $<0.04$ & $<0.014$ & $<0.006$ & $<0.024$ \\
\hline F573 & $<.006$ & $<.008$ & $<.014$ & $<.04$ & $<.014$ & $<.006$ & $<.024$ \\
\hline J1736 & E.001 & $<.007$ & $<.014$ & $<.04$ & $<.014$ & $<.006$ & $<.024$ \\
\hline ST378 & $<.014$ & $<.007$ & E.001 & $<.04$ & $<.014$ & $<.006$ & $<.024$ \\
\hline ST2584 & E.002 & $<.007$ & $<.014$ & $<.04$ & $<.014$ & $<.006$ & $<.024$ \\
\hline \multicolumn{8}{|c|}{ Bedrock wells } \\
\hline CL674 & $<.006$ & $<.008$ & $<.014$ & $<.04$ & $<.014$ & $<.006$ & $<.024$ \\
\hline F91 & E.003 & $<.008$ & $<.014$ & $<.04$ & .002 & $<.006$ & $<.024$ \\
\hline F1042 & $<.014$ & $<.007$ & $<.014$ & $<.04$ & $<.014$ & $<.006$ & $<.024$ \\
\hline F1051 & $<.014$ & $<.007$ & $<.014$ & E.01 & $<.014$ & $<.006$ & $<.024$ \\
\hline H80 & $<.014$ & $<.007$ & $<.014$ & E.01 & $<.014$ & $<.006$ & $<.024$ \\
\hline J836 & $<.014$ & $<.007$ & $<.014$ & $<.04$ & $<.014$ & $<.006$ & $<.024$ \\
\hline ST950 & $<.014$ & $<.007$ & $<.014$ & $<.04$ & $<.014$ & $<.006$ & $<.024$ \\
\hline ST1424 & $<.006$ & $<.008$ & $<.014$ & $<.04$ & $<.014$ & $<.006$ & $<.024$ \\
\hline ST1426 & $<.014$ & $<.007$ & $<.014$ & M & $<.014$ & $<.006$ & $<.024$ \\
\hline ST2074 & $<.014$ & $<.007$ & $<.014$ & $<.04$ & $<.014$ & .003 & $<.024$ \\
\hline ST2291 & $<.014$ & $<.007$ & $<.014$ & $<.04$ & $<.014$ & $<.006$ & $<.024$ \\
\hline ST2758 & $<.014$ & $<.007$ & $<.014$ & E.02 & $<.014$ & $<.006$ & $<.024$ \\
\hline ST3032 & E.031 & .011 & $<.014$ & $<.20$ & $<.014$ & $<.006$ & $<.024$ \\
\hline ST3204 & $<.014$ & $<.007$ & $<.014$ & $<.04$ & $<.014$ & $<.006$ & $<.024$ \\
\hline ST3322 & $<.014$ & $<.007$ & $<.014$ & E.11 & $<.014$ & $<.006$ & E.007 \\
\hline
\end{tabular}

${ }^{1}$ CL, Clinton County; F, Franklin County; H, Hamilton County; J, Jefferson County; ST, St. Lawrence County. 
Table 2-7. Concentrations of volatile organic compounds detected in groundwater samples collected in the St.

Lawrence River Basin, New York, 2010.

[ $\mu \mathrm{g} / \mathrm{L}$, micrograms per liter; (34475), U.S. Geological Survey National Water Information System parameter code; <, less than. Well locations are shown in figures 3 and 4$]$

\begin{tabular}{|c|c|c|c|}
\hline $\begin{array}{c}\text { Well } \\
\text { number }\end{array}$ & $\begin{array}{l}\text { Tetrachloro- } \\
\text { ethene, } \\
\text { unfiltered, } \\
\mu \mathrm{g} / \mathrm{L} \\
(34475) \\
\end{array}$ & $\begin{array}{c}\text { Toluene, } \\
\text { unfiltered, } \\
\mu \mathrm{g} / \mathrm{L} \\
(34010)\end{array}$ & $\begin{array}{c}\text { Trichloro- } \\
\text { methane, } \\
\text { unfiltered, } \\
\mu \mathrm{g} / \mathrm{L} \\
(32106)\end{array}$ \\
\hline \multicolumn{4}{|c|}{ Sand and gravel wells } \\
\hline F543 & $<0.1$ & $<0.1$ & $<0.1$ \\
\hline F573 & $<.1$ & $<.1$ & $<.1$ \\
\hline J1736 & $<.1$ & $<.1$ & $<.1$ \\
\hline ST378 & $<.1$ & $<.1$ & $<.1$ \\
\hline ST2584 & $<.1$ & $<.1$ & $<.1$ \\
\hline \multicolumn{4}{|c|}{ Bedrock wells } \\
\hline CL674 & $<.1$ & $<.1$ & $<.1$ \\
\hline F91 & $<.1$ & $<.1$ & $<.1$ \\
\hline F1042 & $<.1$ & $<.1$ & $<.1$ \\
\hline F1051 & $<.1$ & $<.1$ & .2 \\
\hline H80 & .1 & .1 & $<.1$ \\
\hline J836 & $<.1$ & $<.1$ & $<.1$ \\
\hline ST950 & $<.1$ & $<.1$ & $<.1$ \\
\hline ST1424 & $<.1$ & $<.1$ & $<.1$ \\
\hline ST1426 & $<.1$ & $<.1$ & $<.1$ \\
\hline ST2074 & $<.1$ & $<.1$ & $<.1$ \\
\hline ST2291 & $<.1$ & $<.1$ & $<.1$ \\
\hline ST2758 & $<.1$ & $<.1$ & $<.1$ \\
\hline ST3032 & $<.1$ & $<.1$ & $<.1$ \\
\hline ST3204 & $<.1$ & $<.1$ & $<.1$ \\
\hline ST3322 & $<.1$ & $<.1$ & $<.1$ \\
\hline
\end{tabular}

${ }^{1}$ CL, Clinton County; F, Franklin County; H, Hamilton County; J, Jefferson County; ST, St. Lawrence County. 
Table 2-8. Activities of radionuclides in groundwater samples from the St. Lawrence River Basin, New York, 2010. [pCi/L, picocuries per liter; (01519), USGS National Water Information System parameter code; <, less than; --, not analyzed. Bold values equal or exceed one or more existing or proposed drinking-water standards. Well locations are shown in figures 3 and 4]

\begin{tabular}{|c|c|c|c|}
\hline $\begin{array}{c}\text { Well } \\
\text { number1 }^{1}\end{array}$ & $\begin{array}{l}\text { Gross alpha } \\
\text { radioactivity, } \\
\text { unfiltered, } \\
\text { pCi/L } \\
(01519)\end{array}$ & $\begin{array}{l}\text { Gross beta } \\
\text { radioactivity, } \\
\text { unfiltered, } \\
\text { pCi/L } \\
\text { (85817) }\end{array}$ & $\begin{array}{l}\text { Radon- } \\
222, \\
\text { unfiltered, } \\
\text { pCi/L } \\
\text { (82303) }\end{array}$ \\
\hline \multicolumn{4}{|c|}{ Sand and gravel wells } \\
\hline F543 & 1.0 & $<1$ & 890 \\
\hline F573 & 1.2 & .9 & 420 \\
\hline J1736 & $<1.8$ & 4.1 & 227 \\
\hline ST378 & $<.55$ & .9 & 710 \\
\hline ST2584 & $<.61$ & 1.9 & 940 \\
\hline \multicolumn{4}{|c|}{ Bedrock wells } \\
\hline CL674 & 1.1 & 1.7 & 610 \\
\hline F91 & $<.92$ & $<1.1$ & 390 \\
\hline F1042 & $<.39$ & .8 & 2,580 \\
\hline F1051 & 2.0 & $<.85$ & 17 \\
\hline H80 & 2.1 & 1.4 & 740 \\
\hline J836 & $<1$ & 3.6 & 1,020 \\
\hline ST950 & 3.0 & 4.4 & 137 \\
\hline ST1424 & 2.8 & 5.0 & 164 \\
\hline ST1426 & 6 & 2.7 & 1,440 \\
\hline ST2074 & 16 & 10 & 2,390 \\
\hline ST2291 & $<.51$ & .9 & 460 \\
\hline ST2758 & $<1.1$ & 4.5 & 340 \\
\hline ST3032 & $<1.2$ & 16.1 & -- \\
\hline ST3204 & $<1.8$ & 2.9 & 580 \\
\hline ST3322 & $<.54$ & $<1.3$ & 48 \\
\hline
\end{tabular}

${ }^{1}$ CL, Clinton County; F, Franklin County; H, Hamilton County; J, Jefferson County; ST, St. Lawrence County. 
Table 2-9. Bacteria in groundwater samples collected in the St. Lawrence River Basin, New York, 2010.

[CFU, colony-forming unit; mL, milliliter; (31691), U.S. Geological Survey National Water Information System parameter code; <, less than; >, greater than; --, not analyzed. Bold values indicate detections of coliform bacteria or exceed one or more drinking-water standards. Well locations are shown in figures 3 and 4$]$

\begin{tabular}{|c|c|c|c|c|}
\hline $\begin{array}{c}\text { Well } \\
\text { number1 }\end{array}$ & $\begin{array}{c}\text { Escherichia coli, } \\
\text { unfiltered, } \\
\text { PresencelAbsence } \\
\text { (84385) } \\
\end{array}$ & $\begin{array}{c}\text { Fecal } \\
\text { coliform, } \\
\text { membrane } \\
\text { filtration, } \\
\text { unfiltered, } \\
\text { CFU/100mL } \\
(61215)\end{array}$ & $\begin{array}{l}\text { Heterotrophic } \\
\text { plate count, } \\
\text { unfiltered, } \\
\text { CFU/mL } \\
\text { (31692) }\end{array}$ & $\begin{array}{c}\text { Total } \\
\text { coliform, } \\
\text { membrane } \\
\text { filtration, } \\
\text { unfiltered, } \\
\text { CFU/100mL } \\
\text { (61213) }\end{array}$ \\
\hline \multicolumn{5}{|c|}{ Sand and gravel wells } \\
\hline F543 & Absent & $<2$ & 3 & 3 \\
\hline F573 & Absent & $<2$ & $<1$ & $<1$ \\
\hline J1736 & Absent & $<2$ & $>300$ & $<1$ \\
\hline ST378 & Absent & $<2$ & 1 & $<1$ \\
\hline ST2584 & Absent & $<2$ & 6 & $<1$ \\
\hline \multicolumn{5}{|c|}{ Bedrock wells } \\
\hline CL674 & Absent & $<1$ & 150 & 270 \\
\hline F91 & Absent & $<1$ & 2 & $<1$ \\
\hline F1042 & Absent & $<2$ & 600 & $<1$ \\
\hline F1051 & Absent & $<2$ & 1 & 21 \\
\hline H80 & Absent & $<2$ & 10 & 20 \\
\hline J836 & Present & $<2$ & 29 & $>200$ \\
\hline ST950 & Absent & $<2$ & $<1$ & $<1$ \\
\hline ST1424 & Absent & $<2$ & $<1$ & $<1$ \\
\hline ST1426 & Absent & $<2$ & 290 & $<4$ \\
\hline ST2074 & Present & $<2$ & $>300$ & $>\mathbf{2 0 0}$ \\
\hline ST2291 & Absent & $<2$ & $<1$ & $<1$ \\
\hline ST2758 & Absent & $<2$ & 540 & 20 \\
\hline ST3032 & -- & -- & -- & -- \\
\hline ST3204 & Absent & $<2$ & 1 & $<1$ \\
\hline ST3322 & Absent & $<2$ & $>150$ & $<1$ \\
\hline
\end{tabular}

\footnotetext{
${ }^{1}$ CL, Clinton County; F, Franklin County; H, Hamilton County; J, Jefferson County; ST, St. Lawrence County.
} 
Table 2-10. Physiochemical properties and concentrations of major ions, nutrients, and bacteria in groundwater samples collected in the St. Lawrence River Basin, New York, 2005 and 2010.

[NWIS, National Water Information System; mg/L, milligrams per liter; $\mu \mathrm{S} / \mathrm{cm}$, microsiemens per centimeter at 25 degrees Celsius; CaCO calcium carbonate; ${ }^{\circ} \mathrm{C}$, degrees Celsius; N, nitrogen; P, phosphorus; CFU, colony-forming unit; mL, milliliter; <, less than; E, estimated concentration; U, not detected; lab, laboratory]

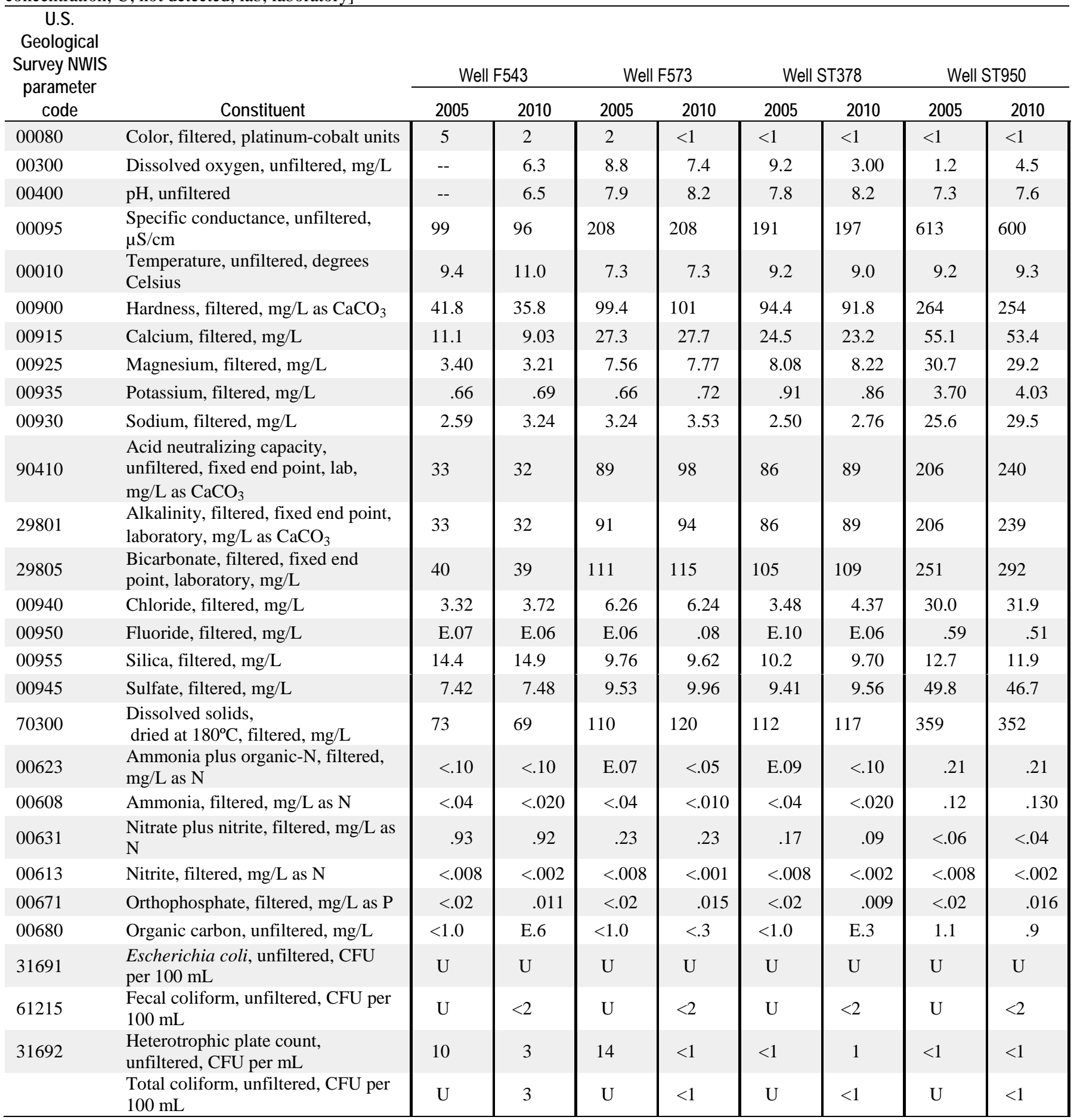


Table 2-11. Concentrations of trace elements and radionuclides in groundwater samples collected in the St.

Lawrence River Basin, New York, 2005 and 2010.

[NWIS, National Water Information System; $\mu \mathrm{g} / \mathrm{L}$, micrograms per liter, pCi/L, picocuries per liter; <, less than, E, estimated concentration] U.S.

\section{Geological}

Survey NWIS parameter code

01105

01097

01002

01007

01012

01020

01027

01034

01037

01042

01046

01045

01051

01132

01056

01055

71900

01062

01067

01147

01077

01082

01059

01092

82303

28011
Constituent

Aluminum, unfiltered, $\mu \mathrm{g} / \mathrm{L}$

Antimony, unfiltered, $\mu \mathrm{g} / \mathrm{L}$

Arsenic, unfiltered, $\mu \mathrm{g} / \mathrm{L}$

Barium, unfiltered, $\mu \mathrm{g} / \mathrm{L}$

Beryllium, unfiltered, $\mu \mathrm{g} / \mathrm{L}$

Boron, filtered, $\mu \mathrm{g} / \mathrm{L}$

Cadmium, unfiltered, $\mu \mathrm{g} / \mathrm{L}$

Chromium, unfiltered, $\mu \mathrm{g} / \mathrm{L}$

Cobalt, unfiltered, $\mu \mathrm{g} / \mathrm{L}$

Copper, unfiltered, $\mu \mathrm{g} / \mathrm{L}$

Iron, filtered, $\mu \mathrm{g} / \mathrm{L}$

Iron, unfiltered, $\mu \mathrm{g} / \mathrm{L}$

Lead, unfiltered, $\mu \mathrm{g} / \mathrm{L}$

Lithium, unfiltered, $\mu \mathrm{g} / \mathrm{L}$

Manganese, filtered, $\mu \mathrm{g} / \mathrm{L}$

Manganese, unfiltered, $\mu \mathrm{g} / \mathrm{L}$

Mercury, unfiltered, $\mu \mathrm{g} / \mathrm{L}$

Molybdenum, unfiltered,

$\mu \mathrm{g} / \mathrm{L}$

Nickel, unfiltered, $\mu \mathrm{g} / \mathrm{L}$

Selenium, unfiltered, $\mu \mathrm{g} / \mathrm{L}$

Silver, unfiltered, $\mu \mathrm{g} / \mathrm{L}$

Strontium, unfiltered, $\mu \mathrm{g} / \mathrm{L}$

Thallium, unfiltered, $\mu \mathrm{g} / \mathrm{L}$

Zinc, unfiltered, $\mu \mathrm{g} / \mathrm{L}$

Radon-222, unfiltered, pCi/L

Uranium, unfiltered, $\mu \mathrm{g} / \mathrm{L}$
Well F543

Well F573

Well ST378

Well ST950

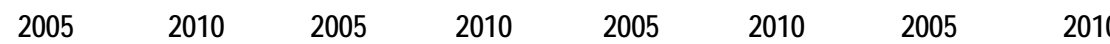

\begin{tabular}{l|l}
4 & $<6$ \\
\hline
\end{tabular}

\begin{tabular}{l|l|l|l}
$<.2$ & $<.4$ & 3 \\
\hline
\end{tabular}

E.09

E.09 $<.18$

7.0

$<.06$

E6.8

E.02

8.3
$<.04$

.43

.063

71.6

7

37

.2

3.

3.4

2.8

$<.010$

E.2

.56

$<.4$

$<.16$

27.8

$<.18$

E1

860

.042

7.6

$<.64$
$<.04$

$<.42$

$<.04$
195

8

56

E 89

.48
1.0
1.9
3.0
$<.010$
.1
E.21
$<.10$
E.01
30.2
$<.12$
E1.9
890
.047

\begin{tabular}{l|l}
$<3$ & $\mathrm{E} 1$
\end{tabular}

.46

\begin{tabular}{c|c|c|}
\hline$<.06$ & 19.5 & 45.6 \\
E4.2 & $<.02$ & $<.06$ \\
\hline
\end{tabular}

$<.04$
.98
.076

$<.05$

.58

$<.04$
36

$<.02 \quad .088$

12.0

$<6$

$<6$

$<3 \quad<6$

$<5$

1.0

\begin{tabular}{l|l}
$<.06$ & $<.0$ \\
1.0 & 1.3 \\
$<.6$ &
\end{tabular}

$<$

6

1.41

1.3 E.

$.3<.6$

$<.010<.005$

$<.6$

$<.010$

\begin{tabular}{c|c|c}
$<6$ & $<2$ & $<6$ \\
$<.4$ & $<2$ &
\end{tabular}

$<6$

$<.4$

.75

\begin{tabular}{rr|r}
.46 & .28 & .75 \\
& 97.1 & 108
\end{tabular}

$<.04$
$<.06$

$<.04$

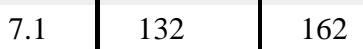

$<.04<.04<.04$

$\begin{array}{ll}\text { E.23 } & .11<.42\end{array}$

$<.04 \quad .210<.04$

\begin{tabular}{l|l|l}
2.2 & 1.6 & 2.2
\end{tabular}

$<6$

$<9$

36

45

.99

23.1

8.0

8.5

$<.010$

$<.8$

$<.010<.010$

.9

$<.36$

$<.10$

$<.02$

\begin{tabular}{l|r}
$<.16$ & $<.01$
\end{tabular}$<.16$

$\begin{array}{ll}73.4 & 76.3\end{array}$

$<.18<.06$

35.0

\begin{tabular}{c|c} 
E1 & $<2.4$ \\
430 & 420
\end{tabular}

420

.374

.097 
Table 2-12. Concentrations of pesticides in groundwater samples collected in St. Lawrence River Basin, New York, 2005 and 2010.

[NWIS, National Water Information System; $\mu \mathrm{g} / \mathrm{L}$, micrograms per liter; <, less than; E, estimated concentration. Bold value indicates detected concentration]

\begin{tabular}{|c|c|c|c|c|c|c|c|c|c|}
\hline \multirow{2}{*}{$\begin{array}{c}\text { U.S. } \\
\text { Geological } \\
\text { Survey } \\
\text { NWIS } \\
\text { parameter } \\
\text { code } \\
\end{array}$} & \multirow[b]{2}{*}{ Constituent } & Wel & 543 & & 573 & Well & T378 & We & T950 \\
\hline & & 2005 & 2010 & 2005 & 2010 & 2005 & 2010 & 2005 & 2010 \\
\hline 82660 & 2,6-Diethylaniline, filtered, $\mu \mathrm{g} / \mathrm{L}$ & $<0.006$ & $<0.006$ & $<0.006$ & $<0.006$ & $<0.006$ & $<0.006$ & $<0.006$ & $<0.006$ \\
\hline 04040 & $\begin{array}{l}\text { 2-Chloro-4-isopropylamino-6-amino- } \\
s \text {-triazine (CIAT), filtered, } \mu \mathrm{g} / \mathrm{L}\end{array}$ & $<.006$ & $<.014$ & $<.006$ & $<.006$ & $<.006$ & $<.014$ & $<.006$ & $<.014$ \\
\hline 49260 & Acetochlor, filtered, $\mu \mathrm{g} / \mathrm{L}$ & $<.006$ & $<.010$ & $<.006$ & $<.010$ & $<.006$ & $<.010$ & $<.006$ & $<.010$ \\
\hline 46342 & Alachlor, filtered, $\mu \mathrm{g} / \mathrm{L}$ & $<.005$ & $<.008$ & $<.005$ & $<.008$ & $<.005$ & $<.008$ & $<.005$ & $<.008$ \\
\hline 34253 & alpha-HCH, filtered, $\mu \mathrm{g} / \mathrm{L}$ & $<.005$ & $<.004$ & $<.005$ & $<.004$ & $<.005$ & $<.004$ & $<.005$ & $<.004$ \\
\hline 39632 & Atrazine, filtered, $\mu \mathrm{g} / \mathrm{L}$ & $<.007$ & $<.007$ & $<.007$ & $<.008$ & $<.007$ & $<.007$ & $<.007$ & $<.007$ \\
\hline 82686 & Azinphos-methyl, filtered, $\mu \mathrm{g} / \mathrm{L}$ & $<.050$ & $<.120$ & $<.050$ & $<.120$ & $<.050$ & $<.120$ & $<.050$ & $<.120$ \\
\hline 82673 & Benfluralin, filtered, $\mu \mathrm{g} / \mathrm{L}$ & $<.010$ & $<.014$ & $<.010$ & $<.014$ & $<.010$ & E.001 & $<.010$ & $<.014$ \\
\hline 04028 & Butylate, filtered, $\mu \mathrm{g} / \mathrm{L}$ & $<.004$ & $<.004$ & $<.004$ & $<.004$ & $<.004$ & $<.004$ & $<.004$ & $<.004$ \\
\hline 82680 & Carbaryl, filtered, $\mu \mathrm{g} / \mathrm{L}$ & $<.041$ & $<.060$ & $<.041$ & $<.060$ & $<.041$ & $<.060$ & $<.041$ & $<.060$ \\
\hline 82674 & Carbofuran, filtered, $\mu \mathrm{g} / \mathrm{L}$ & $<.020$ & $<.060$ & $<.020$ & $<.060$ & $<.020$ & $<.060$ & $<.020$ & $<.060$ \\
\hline 38933 & Chlorpyrifos, filtered, $\mu \mathrm{g} / \mathrm{L}$ & $<.005$ & $<.010$ & $<.005$ & $<.004$ & $<.005$ & $<.010$ & $<.005$ & $<.010$ \\
\hline 82687 & cis-Permethrin, filtered, $\mu \mathrm{g} / \mathrm{L}$ & $<.006$ & $<.014$ & $<.006$ & $<.010$ & $<.006$ & $<.014$ & $<.006$ & $<.014$ \\
\hline 04041 & Cyanazine, filtered, $\mu \mathrm{g} / \mathrm{L}$ & $<.018$ & $<.022$ & $<.018$ & $<.022$ & $<.018$ & $<.022$ & $<.018$ & $<.022$ \\
\hline 82682 & DCPA, filtered, $\mu \mathrm{g} / \mathrm{L}$ & $<.003$ & $<.008$ & $<.003$ & $<.008$ & $<.003$ & $<.008$ & $<.003$ & $<.008$ \\
\hline 62170 & Desulfinylfipronil, filtered, $\mu \mathrm{g} / \mathrm{L}$ & $<.012$ & $<.012$ & $<.012$ & $<.012$ & $<.012$ & $<.012$ & $<.012$ & $<.012$ \\
\hline 39572 & Diazinon, filtered, $\mu \mathrm{g} / \mathrm{L}$ & $<.005$ & $<.005$ & $<.005$ & $<.006$ & $<.005$ & $<.005$ & $<.005$ & $<.005$ \\
\hline 39381 & Dieldrin, filtered, $\mu \mathrm{g} / \mathrm{L}$ & $<.009$ & $<.009$ & $<.009$ & $<.008$ & $<.009$ & $<.009$ & $<.009$ & $<.009$ \\
\hline 82677 & Disulfoton, filtered, $\mu \mathrm{g} / \mathrm{L}$ & $<.02$ & $<.04$ & $<.02$ & $<.04$ & $<.02$ & $<.04$ & $<.02$ & $<.04$ \\
\hline 82668 & EPTC, filtered, $\mu \mathrm{g} / \mathrm{L}$ & $<.004$ & $<.002$ & $<.004$ & $<.006$ & $<.004$ & $<.002$ & $<.004$ & $<.002$ \\
\hline 82663 & Ethalfluralin, filtered, $\mu \mathrm{g} / \mathrm{L}$ & $<.009$ & $<.006$ & $<.009$ & $<.006$ & $<.009$ & $<.006$ & $<.009$ & $<.006$ \\
\hline 82672 & Ethoprop, filtered, $\mu \mathrm{g} / \mathrm{L}$ & $<.005$ & $<.016$ & $<.005$ & $<.016$ & $<.005$ & $<.016$ & $<.005$ & $<.016$ \\
\hline 62169 & $\begin{array}{l}\text { Desulfinylfipronil amide, filtered, } \\
\mu \mathrm{g} / \mathrm{L}\end{array}$ & $<.029$ & $<.029$ & $<.029$ & $<.029$ & $<.029$ & $<.029$ & $<.029$ & $<.029$ \\
\hline 62167 & Fipronil sulfide, filtered, $\mu \mathrm{g} / \mathrm{L}$ & $<.013$ & $<.013$ & $<.013$ & $<.012$ & $<.013$ & $<.013$ & $<.013$ & $<.013$ \\
\hline 62168 & Fipronil sulfone, filtered, $\mu \mathrm{g} / \mathrm{L}$ & $<.024$ & $<.024$ & $<.024$ & $<.024$ & $<.024$ & $<.024$ & $<.024$ & $<.024$ \\
\hline 62166 & Fipronil, filtered, $\mu \mathrm{g} / \mathrm{L}$ & $<.016$ & $<.018$ & $<.016$ & $<.018$ & $<.016$ & $<.018$ & $<.016$ & $<.018$ \\
\hline 04095 & Fonofos, filtered, $\mu \mathrm{g} / \mathrm{L}$ & $<.003$ & $<.004$ & $<.003$ & $<.005$ & $<.003$ & $<.004$ & $<.003$ & $<.004$ \\
\hline 39341 & Lindane, filtered, $\mu \mathrm{g} / \mathrm{L}$ & $<.004$ & $<.004$ & $<.004$ & $<.004$ & $<.004$ & $<.004$ & $<.004$ & $<.004$ \\
\hline 82666 & Linuron, filtered, $\mu \mathrm{g} / \mathrm{L}$ & $<.035$ & $<.060$ & $<.035$ & $<.060$ & $<.035$ & $<.060$ & $<.035$ & $<.060$ \\
\hline 39532 & Malathion, filtered, $\mu \mathrm{g} / \mathrm{L}$ & $<.027$ & $<.016$ & $<.027$ & $<.016$ & $<.027$ & $<.016$ & $<.027$ & $<.016$ \\
\hline
\end{tabular}


Table 2-12. Concentrations of pesticides in groundwater samples collected in St. Lawrence River Basin, New York, 2005 and 2010.-Continued

[NWIS, National Water Information System; $\mu \mathrm{g} / \mathrm{L}$, micrograms per liter, <, less than; E, estimated concentration. Bold value indicates detected concentration]

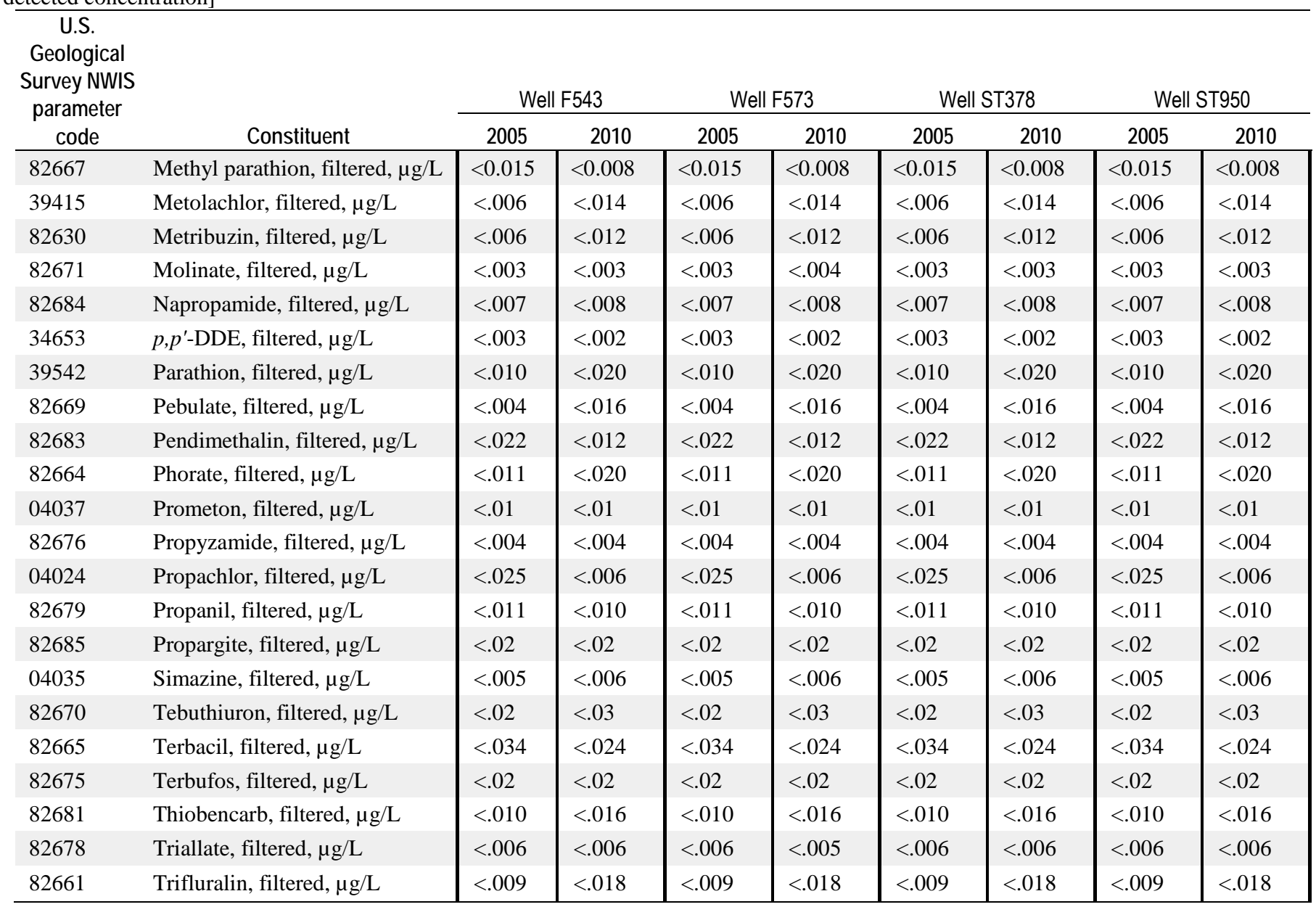


Table 2-13. Concentrations of volatile organic compounds in groundwater samples collected in the St. Lawrence River Basin, New York, 2005 and 2010.

[NWIS, National Water Information System; $\mu \mathrm{g} / \mathrm{L}$, micrograms per liter, <, less than. Bold value indicates detected concentration]

\section{U.S.}

Geological

Survey

NWIS

parameter

code

Well F543 Well F573

Well ST378

Well ST950

\section{6}

1,1,1-Trichloroethane, unfiltered, $\mu \mathrm{g} / \mathrm{L}$

77652

1,1,2-Trichloro-1,2,2-trifluoroethane (CFC-113), unfiltered, $\mu \mathrm{g} / \mathrm{L}$

34496 1,1-Dichloroethane, unfiltered, $\mu \mathrm{g} / \mathrm{L}$

34501 1,1-Dichloroethene, unfiltered, $\mu \mathrm{g} / \mathrm{L}$

34536 1,2-Dichlorobenzene, unfiltered, $\mu \mathrm{g} / \mathrm{L}$

32103 1,2-Dichloroethane, unfiltered, $\mu \mathrm{g} / \mathrm{L}$

34541 1,2-Dichloropropane, unfiltered, $\mu \mathrm{g} / \mathrm{L}$

34566 1,3-Dichlorobenzene, unfiltered, $\mu \mathrm{g} / \mathrm{L}$

34571 1,4-Dichlorobenzene, unfiltered, $\mu \mathrm{g} / \mathrm{L}$

$34030 \quad$ Benzene, unfiltered, $\mu \mathrm{g} / \mathrm{L}$

$32101 \quad$ Bromodichloromethane, unfiltered, $\mu \mathrm{g} / \mathrm{L}$

32104 Tribromomethane, unfiltered, $\mu \mathrm{g} / \mathrm{L}$

$34301 \quad$ Chlorobenzene, unfiltered, $\mu \mathrm{g} / \mathrm{L}$

77093 cis-1,2-Dichloroethene, unfiltered, $\mu \mathrm{g} / \mathrm{L}$

32105 Dibromochloromethane, unfiltered, $\mu \mathrm{g} / \mathrm{L}$

34668 Dichlorodifluoromethane, unfiltered, $\mu \mathrm{g} / \mathrm{L}$

34423 Dichloromethane, unfiltered, $\mu \mathrm{g} / \mathrm{L}$

81576 Diethyl ether, unfiltered, $\mu \mathrm{g} / \mathrm{L}$

81577 Diisopropyl ether, unfiltered, $\mu \mathrm{g} / \mathrm{L}$

$34371 \quad$ Ethylbenzene, unfiltered, $\mu \mathrm{g} / \mathrm{L}$

$50005 \quad$ Methyl tert-pentyl ether, unfiltered, $\mu \mathrm{g} / \mathrm{L}$

$85795 \quad m$ - + $p$-Xylene, unfiltered, $\mu \mathrm{g} / \mathrm{L}$

$77135 \quad o$-Xylene, unfiltered, $\mu \mathrm{g} / \mathrm{L}$

$77128 \quad$ Styrene, unfiltered, $\mu \mathrm{g} / \mathrm{L}$

50004 tert-Butyl ethyl ether, unfiltered, $\mu \mathrm{g} / \mathrm{L}$

$78032 \quad$ Methyl tert-butyl ether (MTBE), unfiltered, $\mu \mathrm{g} / \mathrm{L}$

34475 Tetrachloroethene, unfiltered, $\mu \mathrm{g} / \mathrm{L}$

32102 Tetrachloromethane, unfiltered, $\mu \mathrm{g} / \mathrm{L}$

$34010 \quad$ Toluene, unfiltered, $\mu \mathrm{g} / \mathrm{L}$

34546 trans-1,2-Dichloroethene, unfiltered, $\mu \mathrm{g} / \mathrm{L}$

$39180 \quad$ Trichloroethene, unfiltered, $\mu \mathrm{g} / \mathrm{L}$

34488 Trichlorofluoromethane (CFC-11), unfiltered, $\mu \mathrm{g} / \mathrm{L}$

32106 Trichloromethane, unfiltered, $\mu \mathrm{g} / \mathrm{L}$

$39175 \quad$ Vinyl chloride, unfiltered, $\mu \mathrm{g} / \mathrm{L}$

\begin{tabular}{|c|c|c|c|c|c|c|c|}
\hline 2005 & 2010 & 2005 & 2010 & 2005 & 2010 & 2005 & 2010 \\
\hline$<0.1$ & $<0.1$ & $<0.1$ & $<0.1$ & $<0.1$ & $<0.1$ & $<0.1$ & $<0.1$ \\
\hline$<.1$ & $<.1$ & $<.1$ & $<.1$ & $<.1$ & $<.1$ & $<.1$ & $<.1$ \\
\hline$<.1$ & $<.1$ & $<.1$ & $<.1$ & $<.1$ & $<.1$ & $<.1$ & $<.1$ \\
\hline$<.1$ & $<.1$ & $<.1$ & $<.1$ & $<.1$ & $<.1$ & $<.1$ & $<.1$ \\
\hline$<.1$ & $<.1$ & $<.1$ & $<.1$ & $<.1$ & $<.1$ & $<.1$ & $<.1$ \\
\hline$<.2$ & $<.2$ & $<.2$ & $<.2$ & $<.2$ & $<.2$ & $<.2$ & $<.2$ \\
\hline$<.1$ & $<.1$ & $<.1$ & $<.1$ & $<.1$ & $<.1$ & $<.1$ & $<.1$ \\
\hline$<.1$ & $<.1$ & $<.1$ & $<.1$ & $<.1$ & $<.1$ & $<.1$ & $<.1$ \\
\hline$<.1$ & $<.1$ & $<.1$ & $<.1$ & $<.1$ & $<.1$ & $<.1$ & $<.1$ \\
\hline$<.1$ & $<.1$ & $<.1$ & $<.1$ & $<.1$ & $<.1$ & $<.1$ & $<.1$ \\
\hline$<.1$ & $<.1$ & $<.1$ & $<.1$ & $<.1$ & $<.1$ & $<.1$ & $<.1$ \\
\hline$<.2$ & $<.2$ & $<.2$ & $<.2$ & $<.2$ & $<.2$ & $<.2$ & $<.2$ \\
\hline$<.1$ & $<.1$ & $<.1$ & $<.1$ & $<.1$ & $<.1$ & $<.1$ & $<.1$ \\
\hline$<.1$ & $<.1$ & $<.1$ & $<.1$ & $<.1$ & $<.1$ & $<.1$ & $<.1$ \\
\hline$<.2$ & $<.2$ & $<.2$ & $<.2$ & $<.2$ & $<.2$ & $<.2$ & $<.2$ \\
\hline$<.2$ & $<.2$ & $<.2$ & $<.2$ & $<.2$ & $<.2$ & $<.2$ & $<.2$ \\
\hline$<.2$ & $<.2$ & $<.2$ & $<.2$ & $<.2$ & $<.2$ & $<.2$ & $<.2$ \\
\hline$<.2$ & $<.2$ & $<.2$ & $<.2$ & $<.2$ & $<.2$ & $<.2$ & $<.2$ \\
\hline$<.2$ & $<.2$ & $<.2$ & $<.2$ & $<.2$ & $<.2$ & $<.2$ & $<.2$ \\
\hline$<.1$ & $<.1$ & $<.1$ & $<.1$ & $<.1$ & $<.1$ & $<.1$ & $<.1$ \\
\hline$<.2$ & $<.2$ & $<.2$ & $<.2$ & $<.2$ & $<.2$ & $<.2$ & $<.2$ \\
\hline$<.2$ & $<.2$ & $<.2$ & $<.2$ & $<.2$ & $<.2$ & $<.2$ & $<.2$ \\
\hline$<.1$ & $<.1$ & $<.1$ & $<.1$ & $<.1$ & $<.1$ & $<.1$ & $<.1$ \\
\hline$<.1$ & $<.1$ & $<.1$ & $<.1$ & $<.1$ & $<.1$ & $<.1$ & $<.1$ \\
\hline$<.1$ & $<.1$ & $<.1$ & $<.1$ & $<.1$ & $<.1$ & $<.1$ & $<.1$ \\
\hline$<.2$ & $<.2$ & $<.2$ & $<.2$ & .3 & $<.2$ & $<.2$ & $<.2$ \\
\hline$<.1$ & $<.1$ & $<.1$ & $<.1$ & $<.1$ & $<.1$ & $<.1$ & $<.1$ \\
\hline$<.2$ & $<.2$ & $<.2$ & $<.2$ & $<.2$ & $<.2$ & $<.2$ & $<.2$ \\
\hline$<.1$ & $<.1$ & $<.1$ & $<.1$ & $<.1$ & $<.1$ & $<.1$ & $<.1$ \\
\hline$<.1$ & $<.1$ & $<.1$ & $<.1$ & $<.1$ & $<.1$ & $<.1$ & $<.1$ \\
\hline$<.1$ & $<.1$ & $<.1$ & $<.1$ & $<.1$ & $<.1$ & $<.1$ & $<.1$ \\
\hline$<.2$ & $<.2$ & $<.2$ & $<.2$ & $<.2$ & $<.2$ & $<.2$ & $<.2$ \\
\hline$<.1$ & $<.1$ & $<.1$ & $<.1$ & $<.1$ & $<.1$ & $<.1$ & $<.1$ \\
\hline$<.2$ & $<.2$ & $<.2$ & $<.2$ & $<.2$ & $<.2$ & $<.2$ & $<.2$ \\
\hline
\end{tabular}


This page has been left blank intentionally. 
For more information concerning this report, contact

Director

U.S. Geological Survey

New York Water Science Center

425 Jordan Road

Troy, NY 12180-8349

dc_ny@usgs.gov

or visit our Web site at:

http://ny.water.usgs.gov 